\title{
DEPOSIÇÃO DE MATERIAL ORGÂNICO E NUTRIENTES EM UMA FLORESTA NATURAL E EM UMA PLANTACCÃO DE EUCALIPTOS NO INTERIOR DO ESTADO DE SÃO PAULO
}

\author{
ANTONIO APARECIDO CARPANEZZI \\ Pesquisador da EMBRAPA \\ Bolsista do CNPq
}

Orientador: Fábio Poggiani

\begin{abstract}
Disserłação apresentada à Escola Superior de Agriculłura "Luiz de Queiroz", da Universidade de São Paulo, para obtenção do título de Mestre em Engenharia Florestal.
\end{abstract}

$P|R A C| C A B A$

Estado de São Paulo - Brasil

Joneiro, 1980 
A meus pais e irmãos

A Amador da Silva, mateiro

Para a Preta 


\section{AGRADECI MENTOS}

Ao Professor Fābio Poggiani, pela orientação re cebida.

Ao Conselho Nacional de Pesquisa - CNPq, por bol sa concedida no ano de 1977.

Aos administradores, engenheiros e operārios da Fazenda Rio Claro, da Duraflora - Silvicultura e Comércio Ltda, em Lençóis Paulista, pelo apoio aos trabalhos de campo.

Aos inūmeros amigos que auxiliaram na execução de trabalhos de laboratōrio. 


\section{INDICE}

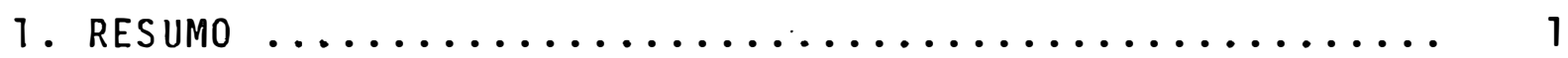

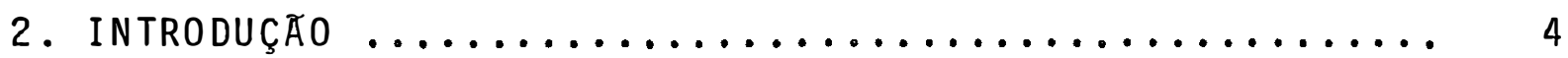

3. REVISATO DE LITERATURA $\ldots \ldots \ldots \ldots \ldots \ldots \ldots \ldots \ldots \ldots \ldots \ldots \ldots \ldots$

3.1. Conceituação do ciclo biológico de nutrí entes de um ecossistema florestal ........... 9

3.2. Importāncia relativa dos componentes da etapa de restituição de nutrientes no c $\underline{i}$ clo biolögico ......................... 10

3.2.1. Deposição de material orgānico ou "litter fall" ................... 10

3.2.2. Lavagem foliar ................. 11

3.2.3. Escoamento pelo tronco .............. 12

3.2.4. A ação das raĩzes ................ 12

3.3. Caracterização das frações do materiàl or gānico decíduo quanto ao peso ............... 13

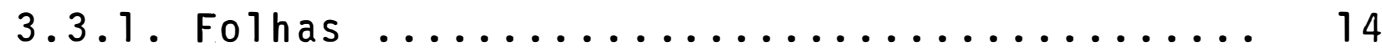

3.3.2. Frações 1enhosas ................. 14

3.3.3. Cascas ....................... 15

3.3.4. Frações menores (miscelânea) .......... 16

3.4. Caracterização das frações do material or gānico decíduo quanto à concentração de

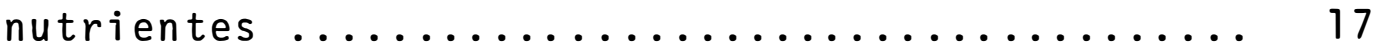

3.4 .1 . Folhas ....................... 17

3.4.1.1. Comparação com outras fra ções ..................... 17

3.4.1.2. Importāncia relativa dos

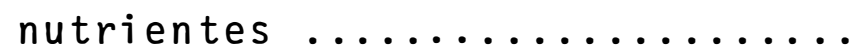


3.4.1.3. Variação estacional......... 18

3.4.2. Frações lenhosas ................ 20

3.4.2.1. Comparação com outras fra ções ................... 20

3.4.2.2. Importāncia relativa dos nutrientes ................. 21

3.4.2.3. Variação estacional ........ 21

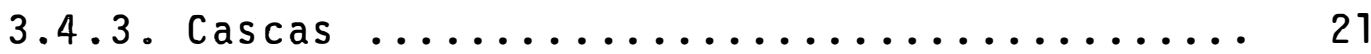

3.4.3.1. Comparação com a fração foliar .................... 21

3.4.3.2. Importāncia relativa dos nutrientes ............... 22

3.4.3.3. Variação estacional ......... 22

3.4.4. Frações menores (miscelānea) .......... 22

3.5. Fatores que afetam as taxas de deposição de material orgānico .................... 23

3.5.1. Coníferas versus folhosas ........... 23

3.5.2. Características ambientais .......... 23

3.5.3. Características do ecossi.stema florestal ..................... 25

3.5.3.1. Plantações florestais ver sus florestas naturais........ 25

3.5.3.2. Relações com a lotação e com a ārea basal ........... 26

3.5.3.3. A adição e a retirada de nutrientes ................ 26

3.5.4. o fator tempo ................. 27

3.5.4.1. Variação estacional da deposição do material or

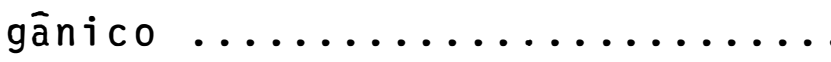


3.5.4.2. Variação anual da depos $\underline{i}$ ção do material orgānico ...... 29

3.5.4.2.1. Fatores cícli cos da comuni

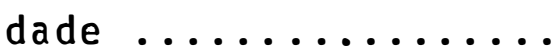

3.5.4.2.2. Fatores climá ticos e bioló gicos

3.5.4.3. A influência do estāgio seral

3.5.5. Taxas de deposição de material or gânico em ecossistemas florestais

3.6. Fatores que afetam a concentração de nutrientes do

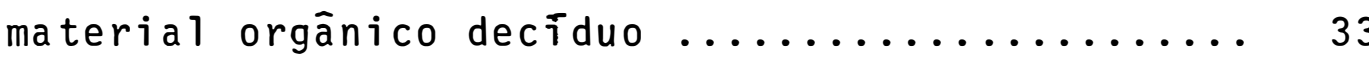

3.6.1. A fertilidade dos solos .............. 33

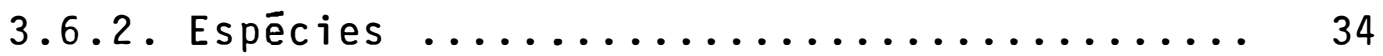

3.7. Taxas de restituição de nutrientes pela deposição de material orgãnico ............. 34

3.8. Aspectos da amostragem da deposição de ma

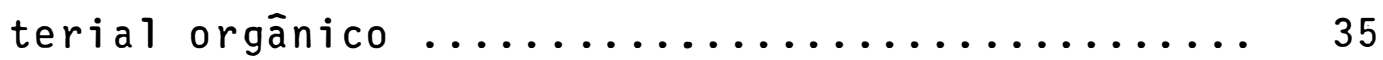

3.8.1. Sobre o local de amostragem ......... 35

3.8.2. Sobre a a dequação da amostragem ........ 36

3.8.3. Nūmero e modo de disposição das

parcelas de amostragem ................ 36

3.8.4. Forma e tamanho das parcelas .......... 37

3.8 .4 .1 . Folhas $\ldots \ldots \ldots \ldots \ldots \ldots \ldots \ldots \ldots$

3.8 .4 .1 .1$. Forma $\ldots \ldots \ldots \ldots \ldots 37$

3.8 .4 .1 .2 . Tamanho ............ 38

3.8.4.2. Frações 1enhosas ............... 39

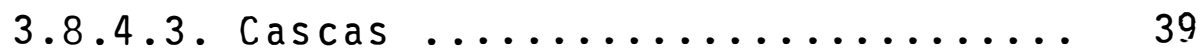


3.8.4.4. Outras frações do mate rial orgānico decíduo ......... 39

3.8 .5 . Frequência das coletas ............ 40

4. MATERIAL E METODOS

4.1. Caracterização das āreas experimentais .........

4.1.1. Localização, clima regional e tọ

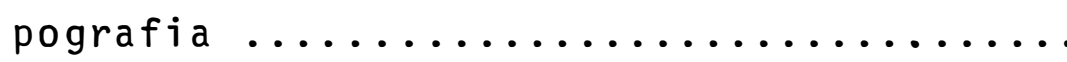

4.1 .2 . Solos ......................... 42

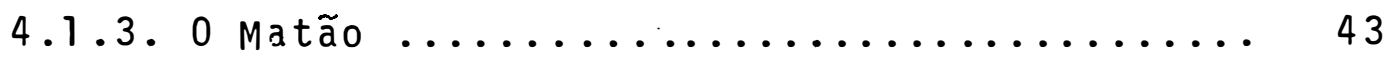

4.1 .4 . 0 eucaliptal .................. 51

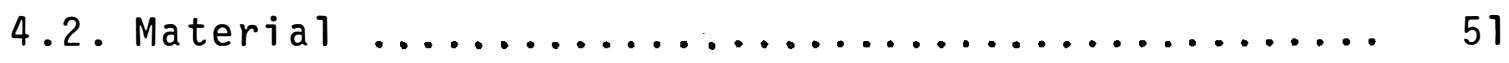

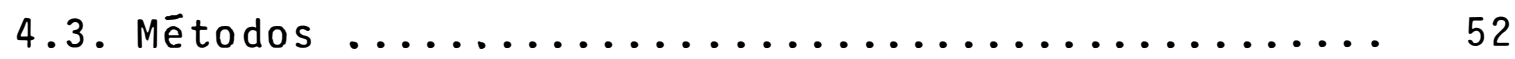

4.3.1. Distribuição das bandejas ........... 52

4.3.2. Período e frequência das coletas ....... 52

4.3.3. Processamento do material coletado .............................. 52

4.3.3.1. Secagem preliminar ......... 52

4.3.3.2. Separação em frações ........ 52

4.3.3.3. Secagem definitiva e pe sagem $\ldots \ldots \ldots \ldots \ldots \ldots \ldots \ldots$

4.3.3.4. Amostragem e moagem para anālise química ............. 53

4.3.3.5. Anālise quĩmica ............ 53

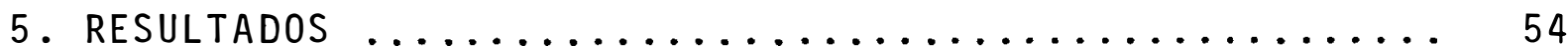

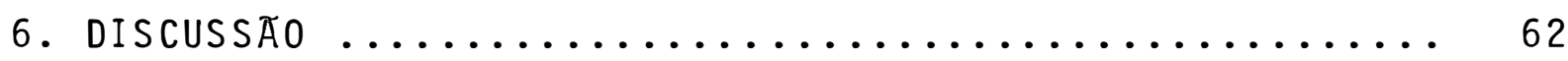

6.1. Aspectos da amostragem da deposição de ma.

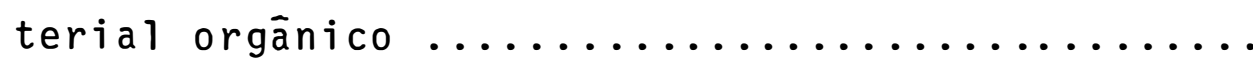


6.1.1. Aspectos da amostragem da deposição de material orgânico na mata ........ 64

6.1.2. Aspectos da amostragem da depos $\underline{i}$ ção de material orgānico no euca liptal

6.2. Variação estacional da deposição de mate

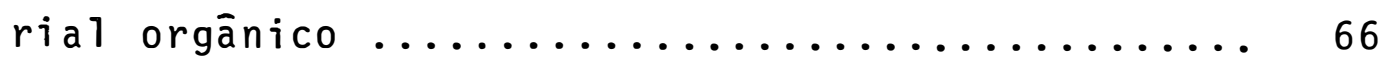

6.2.1. Variação estacional da deposição do material orgānico na mata $\ldots \ldots \ldots \ldots .66$

6.2.2. Variação estacional da deposição de material orgānico no eucaliptal ......... 67

6.3. Deposição anual de material orgānico ......... 70 6.3.1. Deposição anual de material orgâa nico na mata ................... 70

6.3.2. Deposição anual de material orgāa

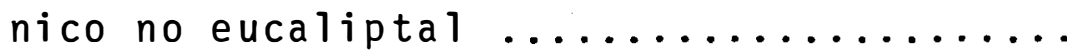

6.4. Variação estacional da concentração de

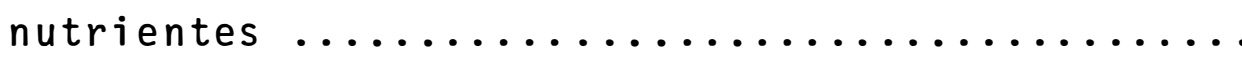

6.5. Concentrações de nutrientes no material deposto no período anual $\ldots \ldots \ldots \ldots \ldots \ldots \ldots \ldots \ldots$

6.6. Deposição anual de nutrientes $\ldots \ldots \ldots \ldots \ldots \ldots . . .60$

6.7. Efeito do eucaliptal sobre o solo ........... 83

6.7.1. Efeito da deposição anual de mate

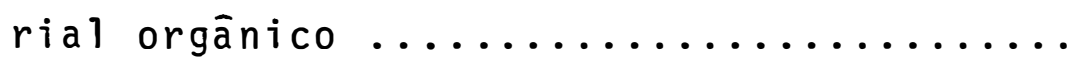

6.7.2. Efeito da deposição anual de nutri entes ....................... 85

6.8. Sugestões para investigações $\ldots \ldots \ldots \ldots \ldots \ldots \ldots .87$

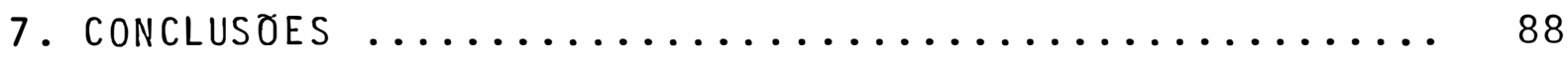

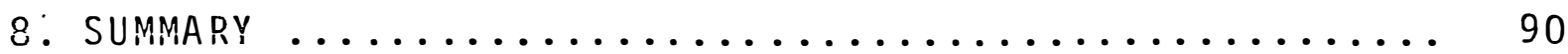

9. LITERATURA CITADA $\ldots \ldots \ldots \ldots \ldots \ldots \ldots \ldots \ldots \ldots \ldots \ldots \ldots$ 


\section{RESUMO}

No Brasil as plantações florestais com espécies de Pinus e Eucalyptus somam quase 3 milhões de hectares. A ta xa anual de aumento de área plantada é 200-250 mil hectares. Todavia, há carēncia de estudos ecológicos sobre plantações florestais e sobre ecossistemas naturais. A dinâmica funcio nal dos ecossistemas é pouco conhecida, e não hā dados numéri cos para avaliar os efeitos da substituição das vegetações na tivas pelas plantações, ou para identificar fatores potencial mente limitantes à produtividade das plantações. Neste estā gio de conhecimentos, investigações sobre o ciclo biológico de nutrientes são consideradas como um passo inicial. importante para a compreensão dos ecossistemas florestais.

0 presente trabalho trata da deposição de mate rial orgānico e de seus nutrientes em dois ecossistemas flo restais contíguos, localizados em Lençóis Paulista, SP. Um dos ecossistemas é uma ārea de floresta ripária subtropical latị foliada semidecî́dua, madura. 0 outro corresponde a uma planta ção comercial de eucaliptos, de 4 a 5 anos de idade, plantada com Eucalyptus saligna Smith e replantada, em cerca de $40 \%$ das covas, com E. grandis Hill ex Maiden. A vegetação original do local da plantação de eucaliptos era um cerrado aberto. 0 solo da mata é mais rico em nutrientes e tem maior teor de argila 
que o solo do eucaliptal. Em ambos os ecossistemas o material decíduo foi coletado em bandejas quadradas de $1 \mathrm{~m}^{2}$ de ārea de recepção, por um período de 15-16 meses. 0 material coletado foi dividido em 3 frações: folhas, ramos e miscelānea. Foram efetuadas anāilises químicas para determinar $\mathrm{N}, \mathrm{P}, \mathrm{K}, \mathrm{Ca}$ e $\mathrm{Mg}$.

A amostragem baseada em bandejas de $1 m^{2}$ foi ade quada somente para a mensuração da queda de folhas. Hā indí cios de que a amostragem por bandejas pode ser utilizada para a medição da fração miscelānea em florestas naturais simila res à de Lençōis Paulista. Para a mensuração de cascas deç̄ duas e da queda de partes lenhosas (incluindo ramos de todos os diāmetros e caules) é recomendada a adoção de parcelas apro priadas.

As médias anuais de deposição de material orgâa nico e nutrientes foram:

\begin{tabular}{|c|c|c|c|c|c|c|}
\hline \multirow{2}{*}{ Ve ge tação } & \multirow{2}{*}{$\begin{array}{c}\text { Material orgānico } \\
(\mathrm{kg} / \mathrm{ha})\end{array}$} & \multicolumn{5}{|c|}{ Nutrientes ( $\mathrm{kg} / \mathrm{ha})$} \\
\hline & & $\mathrm{N}$ & $P$ & $K$ & $\mathrm{Ca}$ & $\mathrm{Mg}$ \\
\hline \multicolumn{7}{|l|}{ Mata } \\
\hline Tota 1 & 10503 & 202,5 & 11,25 & 71,9 & 239,6 & 31,2 \\
\hline Folhas & 6740 & 138,7 & 7,20 & 54,1 & 155,9 & 22,4 \\
\hline \multicolumn{7}{|l|}{ Eucaliptal } \\
\hline Total & 7568 & 39,7 & 2,89 & 11,1 & 34,8 & 15,5 \\
\hline Folhas & 4687 & 32,5 & 2,29 & 9,5 & 24,5 & 11,7 \\
\hline
\end{tabular}

As folhas constituiram a principal fração do material coletado nas bandejas, equivalendo a cerca de dois terços do total, tanto na mata como no eucaliptal. 0 padrão de variação estacional da deposição foliar diferiu nos dois ecossistemas. Na mata, a deposição foi mais intensa no perīo do de agosto a novembro, aproximadamente, o qual normalmente 
corresponde ao final da estação mais fria e de menor precipi tação e ao início das chuvas. No eucaliptal a deposição foli ar mais intensa ocorreu de dezembro a março, aproximadamente, enquadrando-se dentro do período quente e chuvoso.

os valores anuais médios da fração foliar e da deposição total de material orgānico foram maiores na mata. Comparados com valores da literatura mundial obtidos por amos tragem com bandejas, os valores da mata são elevados para a latitude local, e aproximam-se de valores considerados prō prios de florestas tropicais úmidas; as taxas de deposição do eucaliptal são considerados normais para a latitude local. Há indícios de existēncia de relação entre deposição foliare área basal em eucaliptais de alta produtividade do interior do Esta do de São Paulo, em idade próxima ao primeiro corte, e de que o valor da relação é em torno de $230-260 \mathrm{~kg} / \mathrm{m}^{2}$.

Os valores das concentrações em nutrientes das frações decî́duas da mata e os das quantidades de nutrientes vindas ao solo pela deposição do seu material orgānico são pró ximas aos valores mais elevados relatados pela literatura mun dial. Os valores correspondentes do eucaliptal são próximos aos de outros ecossistemas de Eucalyptus, e são acentuadamente inferiores aos valores da mata.

A deposição de material orgānico e seus nutrien tes constituem apenas aspectos parciais da dinâmica de ecossis temas florestais, e necessitam de outras informações para que possam ser claramente interpretadas e para que possam ser uti lizadas na definição de ações práticas, como a adubação. Por este motivo, são fornecidas sugestões para futuras pesquisas, consideradas prioritárias no estágio atual de conhecimentos. 


\section{INTRODUÇAOO}

$\bar{A}$ medida que um ecossistema natural evolui pa ra o estágio clímax sua homeostase aumenta. 0 estágio climax representa o āpice da interação harmōnica dos organismos entre sí e com o ambiente. De outro lado, as plantações efetuadas pelo homem moderno constituem ecossistemas extremamente sim plificados, nos quais se procura manter um estado não equi lị brado entre os seres vivos, mas sim favorāvel às espécies plan tadas, previamente selecionadas para proporcionarem produtivi dade elevada. Todos os fatores de produção são dirigidos para as espécies plantadas; a progressão para o estāgio clímax é visualizada como competição por plantas indesejāveis e siste maticamente sustada.

Estes conceitos permitem a compreensão de ca racterīsticas dos dois modos básicos de produção racional de madeira e produtos florestais: a exploração de florestas natu rais, acompanhada de práticas de manejo, e o estabelecimento de plantações de espécies selecionadas, em monoculturas ou con sōrcios simples. No primeiro caso, a principal vantagem è a maior amplitude de opções para o uso mūitiplo da floresta. Por seu lado, as plantações florestais permitem a obtenção de pro dutividades mais elevadas, fator essencial às finalidades que requerem grandes quantidades de madeira, de qualidade homogé neas, a baixo custo final. 
A diversidade de espécies em formações natu rais no estágio clīmax é função inversa da ocorrēncia, em épo cas atual ou passada, de fatores limitantes aos processos bio lógicos. Nos continentes observa-se, com exceções, um aumento da intensidade dos fatores limitantes com o aumento de latitu de e de altitude, devido às condições climáticas decorrentes serem, de modo progressivo, desfavoráveis aos processos vitais. ODUM (1975, p. 182) relata que nas florestas situadas imedia tamente abaixo da tundra ártica a diversidade de espécies é baixa, muitas vezes com um ou duas espécies apenas. Em con traste, CARVALHO (1978), em levantamento de 35 ha na Amazōnia brasileira, constatou a existência de mais de 80 espécies a böreas comercializáveis.

No aproveitamento de florestas naturais uma bai xa diversidade de espécies torna simples as operações de mane jo, e resulta em maior homogeneidade da matéria prima. De ou tro lado, um número elevado de espécies exige experimentação intensa para definir as práticas de manejo, mais complexas, e a heterogeneidade da matéria prima requer soluções particula res, técnica e economicamente viāveis, para sua utilização. Independente do grau de diversidade, hā necessidade de incor porar-se grandes áreas à atividades florestal, devido à produ tividade não elevada. Estes motivos explicam, em parte, por que a utilização racional de florestas naturais está concen trada em regiões de baixa densidade demográfica, com flores tas extensas e de composição simples, como no Canadá.

A conjuntura atual somente torna economicamen te viāvel a exploração das florestas tropicais brasileiras no tocante a uma pequena fração de espécies que possuem aplića ção jā consagrada. A extração restringe-se às árvores mais va liosas, não sendo aplicadas práticas de manejo que garantiriam a continuidade do recurso florestal. Este quadro poderá mudar com a evolução polîtica e económica do paîs, no sentido de aproveitar suas florestas com maior intensidade e de modo per 
manente. Para is to hā necessidade urgente de maior número de pesquisas, visando obter conhecimentos sólidos sobre aspectos técnicos, económicos, ecológicos e sociais, relacionados ao manejo sustentado das florestas naturais e a outros usos da terra. Uma resenha da problemática relacionada à utilização racional de florestas tropicais úmidas è apresentada por LESLIE (1977), que conclui pelo estabelecimento de plantações como meio de tornar mais segura a oferta futura de madeiras trop $\underline{i}$ cais.

As plantações florestais tem sido realizadas por nações de condições naturais e políticas diversas, como mostram os dados fornecidos por CLEMENTE (1975). Nas regiões do Brasil em que são efetuadas, sua necessidade pode ser ex plicada, basicamente, por dois motivos. Um, a formação cultú ral e econômica de nossa população, que não conduziu à estrú turação de sistemas contīnuos de produção a partir de matas nativas - e sim à extração seletiva destas matas, seguida por sua destruição, na colonização. Outro, o fato de que as nossas mais expressivas formações remanescentes - a floresta amazōn ca e o cerrado - não se prestam a alimentar satisfatoriamente os grandes centros de demanda, localizados nas regiões sul e Sudeste. A Amazōnia, devido à heterogeneidade de suas espécies e a distáncia do mercado consumidor. O cerrado, pelos mesmos motivos e, adicionalmente, pela baixa produtividade e pelas características adaptativas das árvores.

Em 1903 a Companhia Paulista de Estradas de Ferro, em ação pioneira, decidiu estabelecer āreas de planta ções para assegurar, a médio prazo, o suprimento prōprio de suas necessidades de madeira. A tarefa, confiada a Edmundo Na varro de Andrade, resultou na escolha de espécies de Eucalyptus, que mostraram ser superiores às outras, nativas ou introduzi das. O grande sucesso inicial da eucaliptocultura ampliou sua utịização para outros fins e consolidou a plantação flores tal como sistema de produção de madeira em nosso meio. 
A ārea ocupada pelas plantações florestais au mentou de modo significativo a partir de 1967, devido à ado ção de incentivos fiscais ao setor. Segundo BERUTTI (1977), em 1964 havia pouco mais de 500 000ha plantados, dos quais 400000 ha no Estado de São Paulo. Em 1978, o total aproxima-se de 2800 000ha prevendo-se, para o período imediato, uma expan são próxima de 250 000ha ao ano. Espécies de Pinus e Eucalýp tus sã் as mais difundidas ocupando, em 1977 , cerca de $90 \%$ da ārea plantada, como informam GOLFARI et alii (1978, p. 15).

A substituição dos ecossistemas pré-existentes por plantações florestais implica na modificação das condições ecolögicas, o que decorreria da implantação de qualquer outra cultura. Nasce daī, a questão: quais são estas modificações, e quais suas consequēncias futuras? Estas indagações deveriam ser estendidas, tambēm, a outras atividades do setor primário, principalmente àquelas de grande expressão territorial, como a cultura de cana-de-açúcar e a pecuāria.

A ecologia florestal sensu lato permite a com preensão do ecossịstema da plantação florestal através da jun ção de estudos sobre assuntos complementares entre sí, como a dinàmica de populações e as ciclagens de água e nutrientes. os conhecimentos adquiridos permitem localizar fatores poten cial e efetivamente limitantes à produtividade do ecossistema, bem como formular sugestões para ajustá-lo ao conceito de uso mūitiplo de fioresta.

Não obstante sua importāncia, as investigações sobre a ecologia dos povoamentos artificiais são ainda raras no Brasil, havendo concordáncia geral a respeito da necessida de de intensificā-las. São igualmente raras e importantes as investigações ecológicas sobre formações naturais brasileiras, visando sua compreensão e o estabelecimento de valores que pos sam servir de comparação aos observados em povoamentos artifi ciais.

Um levantamento completo sobre a ciclagem de 
nutrientes em um ecossistema florestal requer a investigação, em conjunto, da ciclagem da āgua, tomando-se uma bacia hidro grāfica como unidade de observações. A dimensão desta pesqui sa exige recursos técnicos e financeiros elevados; estes fato res, aliados à falta de consciència ambiental, a tornam pouco freqliente nos países em desenvolvimento, e mesmo nos desenvol vidos.

São mais frequlentes, em qualquer paîs, estudos sobre os aspectos do ciclo biológico de nutrientes que têm maior importāncia a curto ou médio prazo na dināmica funcio nal do ecossistema. Os dados, embora parciais, constituem im portantes informaçōes ao silvicultor e ao ecologista. Neste sentido, os aspectos de maior interesse são a deposição de material orgānico e nutrientes, a decomposição do material or gânico caîdo e a exportação de nutrientes na retirada da ma deira.

Este trabalho foi desenvolvido em dois ecoss is temas florestais contíguos em Lençōis Paulista, Estado de São Paulo. O primeiro é uma ārea remanescente da floresta latifo liada subtropical semidecīdua; o outro, uma plantação comer cial de eucaliptos, em solo cuja vegetação original era cerra do. Os objetivos da investigação foram:

a) estimar a deposição ao solo do material or gânico e seus nutrientes, nos dois ecossis temas; e

b) levantar hipóteses quanto ao efeito do euca liptal sobre características do solo, a par tir das taxas de deposição observadas. 


\section{REVISÃO DE LITERATURA}

3.1. Conceituação do cịclo biológico de nutrientes de um ecossistema florestal

BORMANN e LIKENS (1970) consideram que os nutri entes de um ecossistema encontram-se distribuidos em 4 compar timentos básicos. O compartimento orgānico consiste de organis mos vivos e seus restos. o compartimento de nutrientes dispon veis é composto de nutrientes na solução do solo ou presos às superfícies do complexo argila-hümus. O terceiro compartimento consiste de solo e rochas contendo nutrientes em formas tempo rariamente não disponíveis. O compartimento atmosférico é com posto inteiramente por gases, e inclui o ar do solo.

0 ciclo de nutrientes de um dado ecossistema con siste na movimentação de nutrientes entre seus compartimentos e nas transferēncias entre o ecossistema em estudo e outros ecos sistemas. Em uma floresta, o ciclo de nutrientes é função do tempo, podendo ser reconhecidos os ciclos diário, estacional e anual; o ciclo anual é, sem dūvida, o mais estudado. Segundo REMEZOV (1958), citado em DUVIGNEAUD e DENAEYER-DE SMET (1970), - ciclo anual é uma unidade básica que pode ser usada para com paração e para estudos de ciclos mais longos, como aqueles $1 \underline{i}$ gados à sucessão em ecossistemas florestais. 
Em função dos compartimentos envolvidos no ciclo de nutrientes de uma floresta, 2 caminhos principais podem ser evidenciados: o ciclo biológico ou fechado e o ciclo geoquími co ou aberto. De acordo com DUVIGNEAUD e DENAEYER-DE SMET (1970), o ciclo biológico envolve a circulação de nutrientes entre o solo da floresta e as comunidades vegetal e animal, e compreende as etapas de absorção (principalmente pelas raĩzes), retenção (em cada acrēscimo da biomassa) e restituição.

\subsection{Importancia relativa dos componentes da etapa de restí tuição de nutrientes no ciclo biologico.}

Dados apresentados por DUVIGNEAUD e DENAEYER-DE SMET (1970) exemplificam que a etapa de restituição transfere ao solo parte expressiva dos nutrientes absorvidos. Como pode ser inferido de PRITCHETT (1979, p. 200), a relação deposição: absorção é inversamente proporcional à taxa de expansão de bio massa do ecossistema. Ela é baixa nos ecossistemas em rápido crescimento e teoricamente igual a 1 em ecossistemas no está gio clỉmax, onde a biomassa e a mineralomassa são constantes.

0 retorno de nutrientes ao solo é efetuado por 5 componentes: a deposição do material orgānico ou "litter fall", a lavagem foliar ou das copas, a lavagem por escoamento pelo tronco, a produção de exsudatos pelas raizes e a morte de raí zes.

3.2.1. Deposição de material orgānico ou "litter fall"

A deposição de material orgānico ou "litter fall" é considerada, tradicionalmente, como o mais importante modo de transferéncia de nutrientes da vegetação ao solo. Além dís so, o material orgānico depositado permite a existéncia de uma grande variedade de nichos para a fauna e microrganismo e è a fonte para a matéria orgānica coloidal dos solos. As taxas do ciclo da água no interior do ecossistema florestal e a proba 
bilidade de ocorrēncia de incêndios também sao fortemente rela cionadas com a manta orgânica do piso florestal.

A deposição de material orgānico e a de seus nutrientes serão abordadas, com detalhes, nos îtens 3.3 . e se guintes.

\subsubsection{Lavagem foliar}

CURLIN (1970) considera que a lavagem foliar é, após a deposição de material orgànico,o mais importante meio de retorno de nutrientes ao solo e indica, baseado em informes

de literatura, que os elementos mais susceptîiveis $\bar{a}$ lavagem são, por ordem decrescente, $\mathrm{K}, \mathrm{Ca}, \mathrm{N}$ e P. HENDERSON et alii (1977) verificaram, em 4 ecossistemas florestais do Tenessee, que os elementos mais susceptíveis à lavagem foram $\mathrm{K}>\mathrm{Ca}>\mathrm{Mg}>$ $P>N$. Citando TUKEY (1962), SPURR e BURTON (1973, p. 181) relá tam que os nutrientes mais facilmente removidos pela lavagem foliar incluem $\mathrm{K}$, $\mathrm{Na}, \mathrm{Ca}$ e $\mathrm{Mg}$.

$$
\text { BERNHARD - REVERSAT (1976) apresentou dados re }
$$

ferentes a duas florestas naturais e a duas plantações de Te $\underline{r}$ minalia ivorensis, na Costa do Marfim. No ciclo anual de cada um dos ecossistemas as quantidades de $K$ e $P$ decorrentes da la vagem foliar foram, respectivamente, cerca de duas vezes maior e igual às restituídas pela deposição do material orgânico. Pa ra os demais nutrientes a participação percentual da lavagem foliar em relação ao material orgānico deposto situou-se en tre os seguintes extremos: $\mathrm{Mg}=23,1$ e 117,$1 ; \mathrm{Ca}=18,1$ e $38, \overline{4}$ e $N=11,5$ e 37,9 .

Os trabalhos de WILL (1959), NYE (1961), ATTIWILL (1966), CARLISLE et alii (1966), REINERS (1972), WELLS et alii (1974) e MILLER et alii (1976b) apresentam outros exemplos da importancia da lavagem foliar na restituição de nutrientes ao solo. 


\subsubsection{Escoamento pelo tronco}

Informações de diversos autores reunidas por LIMA (1975) indicam que o arraste de nutrientes atravēs do es coamento pelo tronco parece desempenhar papel importante nas condições quîmicas do solo das imediações do tronco. Entretan to, CURLIN (1970) considera que na etapa de restituição de nu trientes ao solo o escoamento pelo tronco contribui com quanti dades insignificantes, quando comparado à lavagem foliar.

Em povoamento de 34 anos de Alnus rubra. TURNER et alii (1976) constataram as seguintes participações do escoa mento pelo tronco, em relação percentual ao total de nutrien tes depositado pelo material orgânico caído: $\mathrm{N}=0,09 ; \mathrm{P}=$ tra ço; $\mathrm{K}=0,59 ; \mathrm{Ca}=0,24 ; \mathrm{Mg}=0,66 \mathrm{e} \mathrm{Mn}=0,04$.

Dados sobre a participação do escoamento pelo tronco na restituição de nutrientes ao solo tambēm foram obti dos por TARRANT et alii (1968), DENAEYER-DE SMET (1969), WELLS et alii (1972), EATON et alii (1973) e MILLER et alii (1976b).

\subsubsection{A ação das rāizes}

Há 2 modos pelos quais as raízes podem transfe rir nutrientes ao solo: a) pela morte de massas radiculares e b) através de exsudatos radiculares. Ambos são pouco estudados.

Segundo CURLIN (1970) a importãncia de exsuda tos das raízes na restituição de nutrientes ao solo é desconhe cida, devido às dificuldades de mensuração.

Em floresta de folhosas do leste dos Estados Uni dos, SMITH (1976) determinou que as 3 principais espécies arbō reas transferiram ao solo, por exsudações radiculares, as se guintes quantias, em $\mathrm{Kg} / \mathrm{ha} / a n o: \mathrm{N}$ total $=0,81 ; \mathrm{K}=8,05 ; \mathrm{P} \equiv$ $\mathrm{PO}_{4}=0,22 ; \mathrm{Ca}=3,55 ; \mathrm{Mg}=0,18 ; \mathrm{Na}=34,23$ e $\mathrm{Cl}=1,84$. 
GREENLAND e KOWAL (1960), citados por DOMMERGUES (1963), estimaram em $2400 \mathrm{Kg} / \mathrm{ha} / a n o$ a incorporação de materi al orgānico ao solo pela morte de raízes, em floresta tropical úmida de Ghana.

Em povoamentos de Pinus taeda, investigações de WELLS e JORGENSEN (1975) e HENDERSON e HARRIS (1975), citados por MILLER et alii (1976b), demonstraram que a transferéncia anual de $\mathrm{N}$ ao solo pela morte de raízes é superior ao valor proporcionado pela queda de material orgānico.

Outros dados sobre a restituição de nutrientes ao solo através da morte de raĩzes podem ser examinados em OVINGTON (1962).

\subsection{Caracterização das frações do material orgānico decĩ duo quanto ao peso}

0 material orgānico decīduo é constituīdo por folhas, gravetos, ramos, caules, cascas, frutos, flores, par tes vegetais não identificadas e cadáveres e dejetos de an $\underline{i}$ mais. As folhas constituem, sem dūvida, a fração mais estudada.

Há dificuldades em estabelecer generalizações sobre a importáncia dos componentes não foliares - casca, teci dos lenhosos, frutos e outros - devido às metodologias emprega das nos trabalhos experimentais. Nem todos os autores mostram preocupação em obter amostragens adequadas; dentre os casos afir mativos, a maior parte ocupa-se exclusivamente com as folhas. os demais materiais, além de avaliados com precisão insatisfa tōria, são divididos em frações sem que haja uma regra geral para esta partilha. Cada pesquisador a efetua em função da fí nalidade principal de investigação ou de características ine rentes ao material orgānico depositado no ecossistema estudado.

E importante ressaltar que, com raras exceções, 
a amostragem da deposição de material orgānico ē efetuada utilizando exclusivamente bandejas de captação de ārea entre 0,1 e $2,0 \mathrm{~m}^{2}$. Estas dimensões impedem, automaticamente, a mensu ração de certos componentes, como caules ou ramos grossos, e conduzem a uma subestimação do total de material orgānico decí duo. Neste trabalho, salvo indicação em contrário, os totais de deposição e a participação de cada componente referem-se ex clusivamente ao material coletado nas bandejas.

\subsubsection{Folhas}

As folhas são tidas tradicionalmente como a mais importante fração do material orgânico decĩduo. Reunindo os da dos de uma revisão mundial, BRAY e GORHAM (1964)concluíram que nas diferentes zonas macro-ecológicas consideradas a participa ção das folhas situou-se entre 58 e $79 \%$ do material orgānico caído.

Estudando 5 florestas de idades distintas de Eucalyptus maculata, Mc COLL (1966) constatou que a participa ção das folhas situou-se entre 42,7 e $68,8 \%$ do peso total anual do material orgānico deposto.

Em 3 formações de Eucalyptus regnans, de 23, 52 e cerca de 220 anos ao início dos trabalhos, ASTHON (1975) ve rificou que as folhas constituíram 58,7, 43,2 e 51,8\% do total deposto, respectivamente.

Mais exemplos podem ser encontrados nos traba Ihos de KLINGE e RODRIGUES (1968a), HURD (1971), GOSZ et alii (1972), LANG (1974) e EDWARDS (1977), entre outros.

3.3.2. Frações lenhosas

A reunião de dados de Mc COLL (1966), KLINGE e 
RODRIGUES (1968a), ASTHON (1975) e BERNHARD-REVERSAT (1976), obtidos pela amostragem convencional, por bandejas, situa a participação destas frações entre 5 e $30 \%$ do peso total. Resul tados de diversos autores, coletados por BRAY e GORHAM (1964), indicaram participações não superiores a $15 \%$.

Mensurações baseadas em parcelas de amostragem específicas para frações lenhosas, realizadas por GOSZ et ali $i$ (1972) e MALAISSE et alii (1975), apontaram contribuições das frações lenhosas equivalentes a 36,3 e $56,9 \%$, respectivamente, do total de material orgànico caído.

Em povoado de Alnus rubra de 34 anos, TURNER et alii (1976) verificaram que a participação de partes lenho sas (incluindo caules), foi equivalente a $78,6 \%$ do total. os autores relacionaram a contribuição elevada ao estado do povoa mento, que estava em degeneração, pois Alnus rubra é espécie pí oneira de vida curta.

Como abordado no îtem 2.5.4.3., hā indicações de que a participação de partes lenhosas na deposição de mate rial orgânico pode ser associada de modo direto ao estágio se ral.

\subsubsection{Cascas}

A participação das cascas, tomadas isoladamente, em relação ao peso total do material orgānico depositado, de pende principalmente das espécies envolvidas. BRAY e GORHAM (1964) afirmam ser desprezível a fração casca no material orgâa nico depositado por espécies de casca não decídua, como Fagus spp e carpinus spp, e que povoamentos de espécies de cascas de cíduas, como alguns eucaliptos, apresentam elevada deposição.

Adotando amostragem em separado para frações le nhosas, GOSZ et alii (1972) verificaram, em floresta nativa 
de folhosas de New Hampshire, que a fração casca representou apenas $1,7 \%$ do total. Segundo ọs autores, as 3 principais especies da floresta, Acer saccharum, Betula allegheniensis e Fagus grandifolia apresentam, nesta ordem, decréscimo na deciduidade da casca e contribuiram, respectivamente, com 51,1, 31,2 e $16,2 \%$ da fração casca.

Em 5 florestas de diferentes idades de Eucalyp tus maculata, Mc COOL (1966) constatou que a contribuição de casca ao total de material orgānico depositado situou-se entre 9,4 e $45,8 \%$. Em 3 estágios sucessōrios de florestas naturais de Eucalyptus regnans, investigados por ASHTON (1975), a casca deste eucalipto representou de 13,9 a $18,1 \%$ do total deposita do nas bandejas.

KLINGE e RODRIGUES (1968a) e BERNHARD-REVERSAT (1976) constituem exemplos de pesquisadores que não consideram a casca per si como fração do material orgānico decīduo.

\subsubsection{Frações menores (miscelānea)}

Os componentes do material orgānico depositado, que são de menor importáncia quantitativa - como frutos, flo res, partes vegetais não identificadas, cadáveres e dejeções de animais - em poucas ocasiões tem sido considerados separada mente, sendo comumente reunidos em um único ou em pouco grupos.

Em 5 florestas de idade distintas de Eucalyptus maculata investigadas por Mc COLL (1966), as somatórias das frações miscelānea e frutos corresponderam a valores entre 0,7 e $7,6 \%$ do material orgànico coletado nas bandejas.

Em investigação em floresta de terra firme prō xima a Manaus, KLINGE e RODRIGUES (1968a) denominaram "frutos" à fração formada por frutos, flores, botões, sementes, cascas e outras partes vegetais não identificadas. Nos anos de 1963 
e.1964 a participação deste conjunto correspondeu a 2,5 e 7,5\%, respectivamente, dos totais depositados.

Em 4 ecossistemas florestais investigados por BERNHARD-REVERSAT (1976) - duas florestas naturais e duas plan tações de Terminalia ivorensis, na Costa do Marfim - a contri buição da:fração "flores e frutos" situou-se entre 4,0 e 10,9\%.

Outras informações sobre a participação de com ponentes menores na deposição de material orgānico são fornecí dos por GOSZ et alii (1972), EGUNJOBI (1974) e ASHTON (1975).

\subsection{Caracterização das fraçōes do material orgânico decí duo quanto à conceîtuação em nutrientes.}

Segundo CURLIN (1970) as partes de uma arvore obedecem à seguinte ordem, quanto à concentração percentual proporcionada pelo total de nutrientes: folhas > casca > ramos $>$ tronco > raizes. 0 autor ressalta, ainda, que estruturas $1 \underline{\mathbf{j}}$ gadas à reprodução podem apresentar-se notavelmente ricas em certos elementos.

\subsubsection{Folhas}

\subsubsection{Comparação com outras frações}

As folhas apresentam concentração elevada de nu trientes em relação ao total de material orgānico decíduo. Por exemplo, os dados de GOSZ et alii (1972), referente a flores ta de folhosas em New Hampshire, revelam que o total de 12 nu trientes (inclusive $\mathrm{Na}$ ) conferiu às folhas a concentração de $3,09 \%$, contra $1,96 \%$ do conjunto remanescente, o qual incluiu ra mos grossos e caules.

Sem dūvidas outras frações podem apresentar con centrações maiores que as das folhas, para um ou mais nutrientes. 
Resultados de BERNHARD-REVERSAT (1976) sobre plantação de Terminalia ivorensis em Yapo, na Costa do Marfim, mostraram que as concentrações percentuais para $P$ e $K$ foram mais elevadas na fração "flores e frutos", e que a fração "madeira" foi superi or às demais quanto ao $\mathrm{Ca}$.

\subsubsection{Importância relativa dos nutrientes}

Segundo CURLIN (1970) as folhas decîduas contém nutrientes na sequência $\mathrm{N}>\mathrm{Ca}>\mathrm{K}>\mathrm{P}$, embora as espécies cal cícolas possam conter mais Ca que N. Em floresta de folhosas no leste dos Estados Unidos, GOSZ et alii (1972) constataram a sequência $\mathrm{N}>\mathrm{Ca}>\mathrm{K}>\mathrm{Mg}>\mathrm{P}$ no ciclo anual. Em plantações de Eucalyptus saligna de 6 anos em Piracicaba, SP, os resultados de POGGIANI (1976) conduziram à ordem $\mathrm{Ca}>\mathrm{N}>\mathrm{K}>\mathrm{Mg}>\mathrm{P}$, tam bēm em ciclo anual.

Outros exemplos, que levam à generalização $N ?$ $\mathrm{Ca}>\mathrm{K} \geqslant \mathrm{Mg}>\mathrm{P}$, foram fornecidos por NYE (1961), KLINGE $\mathrm{e}$ RODRIGUES (1968b), WEBB et alii (1969), CORNFORTH (1970), ASHTON (1975), BERNHARD-REVERSAT (1976), TURNER et alii (1976) e GESSEL e TURNER (1976).

\subsubsection{Variação estacional}

Segundo KRAMER e KOSLOWSKI (1972, p, 297) è co nhecido que os teores de $N, P$ e $K$ decrescem nas folhas em abci são, admitindo-se que sejam transportados a outros tecidos da ārvore: Em condições temperadas, DENAEYER-DE SMET (1969) e DUVIGNEAUD e DENAEYER-DE SMET (1970) incluem a lavagem foliar como fator do decréscimo outonal. Todavia, NYE (1961) levantou a hipótese que em condições tropicais o deslocamento de $\mathrm{N}$ das folhas decīduas não é tão intenso quanto em condições tempera das. 
A imobilidade do Ca também é conhecida. CURLIN (1970), referindo-se ao comportamento de N, P, K e Ca em espé cies de clima temperado, afirma que as quantidades destes ele mentos na folha decîdua são menores do que na folha madura, com exceção do Ca. DUVIGNEAUD e DENAEYER-DE SMET (1970) e SAUVAGEOT (1973) forneceram outros exemplos sobre a imobilidade do Ca.

Informações sobre o comportamento do $M g$ não são acordantes. DUVIGNEAUD e DENAEYER-DE SMET (1970), GOSZ et alii (1972) e SAUVAGEOT (1973) o indicam como elemento não móvel ou pouco móvel. MEYER et alii (1970, p. 328), KRAMER e KOSLOVSKI (1972, p. 323) e EPSTEIN (1975, p. 61) são unânimes em afirmar que o Mg pode deslocar-se facilmente dos órgäos mais velhos pa ra os mais jovens. Comparando folhas jovens e decíiduas presen tes no material orgānico depositado por Pseudotsuga menziesii, GESSEL e TURNER (1976) verificaram que as folhas jovens apre sentam maior concentração de $\mathrm{N}, \mathrm{P}, \mathrm{K}$ e $\mathrm{Mg}$ e menor teor de $\mathrm{Ca}$.

Normalmente o perīodo de máxima deposição fol $\underline{i}$ ar de um povoamento qualquer corresponde à queda de folhas mais velhas, naturalmente decíduas. As características de movimenta ção de nutrientes podem, pois, ter reflexos sobre a variação estacional de nutrientes da fração foliar do material orgāni co depositado. 0 caso mais comum - embora em muitas investiga ções não seja observado - é o aumento das concentraçōes de $\mathrm{Ca}$, e eventualmente $\mathrm{Mg}$, na estação de máxima deposição, juntamente com o decréscimo das concentrações de nutrientes móveis. Exem plos foram fornecidos por KLINGE e RODRIGUES (1968b), KAWAHARA e TSUTSUMI (1971), GOSZ et alii (1972), AUSSENAC et alii (1972) e SAUVAGEOT (1973).

WEBB et alii (1969) e CORNFORTH (1970) não cons tataram variação estacional nas concentrações de nutrientes da fração foliar, embora tenha ocorrido variação estacional da de posição. 
Como indicado por WEBB et alii (1969), GOSZ et alii (1972) e GESSEL e TURNER (1976), a queda acentuada de fó lhas jovens, não decî́duas, pode originar concentrações eleva das de nutrientes móveis.

\subsubsection{Frações lenhosas}

\subsubsection{Comparação com outras frações}

Resultados obtidos por MORRISON (1973), JOHNSON e RISSER (1974) e JORGENSEEN et alii (1975) exemplificam a re dução da concentração percentual de nutrientes com aumento do diāmetro das partes lenhosas, em ārvores vivas. Em JOHNSON e RISSER (1974) a exceção apresentada pelo Ca, no conjunto forma do por ramos grandes e troncos, pode ser associada à alta con centração de Ca na casca, de $9,0 \%$.

0 teor de nutrientes das partes lenhosas do ma terial orgānico depositado tambēm apresenta-se como função in versa dos diāmetros envolvidos. Dados de MILLER et alii (1976b), referentes a Pseudotsuga menziesii, indicam que a concentração de $N$ no material caído obedeceu a sequência acículas > grave tos > ramos. A comparação entre frações lenhosas apresentadas por GOSZ et alii (1972) mostra que com o aumento de diāmetro houve decrēscimo na concentração de nutrientes, considerados no total ou isoladamente.

Comparadas com a fração foliar, as partes lenho sas do material decíduo normalmente apresentam baixa concentra ção de nutrientes, considerados em conjunto ou isoladamente. Há eventuais exceções para $\mathrm{Ca}$ em peças de pequeno diāmetro, co mo demonstram os resultados expostos por ATTIWILL (1968), KLINGE e RODRIGUES (1968b), GOSZ et alii (1972) e BERNHARD-REVERSAT (1976).

A importāncia da casca na deposição de nutrien 
tes por estruturas lenhosas é significativa. Em. ārvore de Quercus robur, DUVIGNEAUD e DENAEYER-DE SMET (1970) constata ram que as concentrações de nutrientes das cascas são superio res às dos tecidos lenhosos correspondentes. Em sua investiga ção, GOSZ et alii (1972) admitiram que os nutrientes vindos ao solo na fração ramos aparentemente encontravam-se concentrados na casca e nas gemas, uma vez que os tecidos lenhosos apresen tariam nīveis bastante inferiores.

\subsubsection{Importāncia relativa dos nutrientes}

Os dados fornecidos por NYE (1961), ATTIWILL (1968), KLINGE e RODRIGUES (1968b), GOSZ et alii (1972), ASHTON (1975), BERNHARD-REVERSAT (1976) e TURNER et alii (1976), refe rentes a partes lenhosas de diâmetros variados e com casca, in dicam que a concentração de nutrientes segue a ordem $\mathrm{Ca} \gtrless \mathrm{N} \gg$ $K \gtrless M g \gtrless P$.

\subsubsection{Variação estacional}

As pesquisas sobre variação estacional de nutri entes em frações do material orgānico decīiduo tem sido dedica das principalmente às folhas, sendo pequeno o conhecimento so bre as demais frações. KAWAHARA e TSUTSUMI (1971) não a cons tataram em ramos, casca e outras frações.

\subsubsection{Casca}

\subsubsection{Comparação com a fração foliar}

Dados comparativos entre casca e folha como fra ções do material orgānico decīiduo são escassos. Os nūmeros apre sentados por GOSZ et alii (1972) e ASHTON (1975) indicam que a concentração proporcionada pela somatōria de N, P, K, Ca e Mg foi superior nas folhas. 
Informações sobre concentrações de nutrientes em cascas de ārvores vivas, apresentadas por SETH et alii (1963), MC COLL (1969), DUVIGNEAUD e DENAEYER-DE SMET (1970), YOUNG (1971), JOHNSON E RISSER (1974) e JOHNSTON E BARTOS (1977) re velam que os teores de Ca podem ser elevados, mostrando-se prō ximos ou superiores aos valores comumentes encontrados em fo Thas decĩduas.

\subsubsection{Importância relativa dos nutrientes}

A reunião de informações fornecidas por N.YKVIST (1968), Mc COLL (1969), DUVIGNEAUD e DENAEYER-DE SMET (1970), YOUNG (1971), GOSZ et alii (1972), JOHNSON e RISSER (1974), ASHTON (1975), JORGENSEN et alii (1975) e JOHNSTON e BARTOS (1977) indica que as concentrações de nutrientes na casca en contram-se na sequência $\mathrm{Ca} \geqslant \mathrm{N}>\mathrm{K} \geqslant \mathrm{Mg}>\mathrm{P}$.

\subsubsection{Variação estacional}

No Japão, KAWAHARA e TSUTSUMI (1971) não constą taram variação estacional na concentração de nutrientes em cas cas do material orgânico decíduo de 6 ecossistemas florestais.

\subsubsection{Frações menores (miscelānea)}

As frações menores do material orgānico decīduo envolvem normalmente flores, frutos, sementes, insetos e seus dejectos e outros componentes, em proporções não fixas. Embora variáveis entre os ecossistemas, tais frações costumam apresen tar concentração apreciável de nutrientes, quando comparadas com a fração foliar.

Na pesquisa de KLINGE e RODRIGUES (1968b) a fra ção mista "frutos" situou-se acima da fração foliar, quanto $\bar{a}$ somatōria das concentrações de P, K, Ca e Mg. 
sobre deposição de material orgānico em plantações de Terminalia ivorensis, em duas localidades da Costa do Marfim. As concen trações totais (somatōria de $\mathrm{N}, \mathrm{P}, \mathrm{K} \mathrm{Ca}$ e $\mathrm{Mg}$ ) da fração foliar e da fração "flores e frutos" foram aproximadamente equivalen tes, nos 2 locais. Em ambos os locais a fração "flores e fru tos" apresentou-se com baixas concentrações de $\mathrm{Ca}$ e $\mathrm{Mg}$, quando cotejada com a fração foliar.

GOSZ et alii (1972) e EGUNJOBI (1974) apresenta ram outros exemplos de concentrações elevadas de nutrientes das frações menores do material orgânico caído.

\subsection{Fatores que afetam as taxas de deposição de material orgānico}

\subsubsection{Conīferas versus folhosas}

Analisando dados referentes à zona temperada fria do hemisfério norte, BRAY e GORHAM (1964) concluíram que as conīferas situaram-se aproximadamente 17 e $8 \%$ acima das fo Thosas, quanto ao total de material orgánico depositado e à fra ção foliar, respectivamente. Os autores verificaram, todavia, que povoamentos reunidos em àreas menores nem sempre seguem es ta tendência. Os valores superiores apresentados pelas conífe ras foram atribuídos ao fato de serem perenifólias; indices ele vados alcançados pelas folhosas foram explicados como decorrēn cia de ocuparem preferencialmente solos mais férteis.

\subsubsection{Caracterīsticas ambientais}

A deposição de material orgānico é um dos compo nentes da produtividade primária líquida de um ecossistema flo restal. E compreensível, pois, que ela seja afetada pelas con dições ambientais. 
BRAY e GORHAM (1964) constataram que as taxas de deposição de material orgânico estão diretamente associadas com as condições ambientais controladoras da produtividade bio 1ógica. Os autores e DOMMERGUES (1963) forneceram nūmeros indi cativos do comportamento de ecossistemas florestais em diferen tes zonas macro-ecológicas.

Dentro de cada faixa macro-ecológica há varia ções ambientais cujos efeitos sobre a capacidade produtiva 1o cal podem acarretar alterações nas taxas de deposição de mate rial orgânico. BRAY e GORHAM (1964) consideraram, como as mais importantes fontes de variações locais, a altitude, a face de exposição, a fertilidade quīmica e a āgua do solo. Pode-se cí tar, como exemplos corroboradores, os resultados de AUSTRALIA (1967) e DENEV (1975).

ZAVITKOVISKI e NEWTON (1971) apontaram exemplos antagônicos, concluindo que a correlação direta entre a depos $\underline{i}$ ção de folhas e a capacidade produtiva local não pode ser gene ralizada para comunidades de coníferas ou folhosas sem informa ções adicionais. Em parte, isto é consequēncia de que as folhas representam apenas parte do material orgânico depositado. As considerações de GRUBB (1977) são exemplificadoras. Referindose a florestas tropicais ūmidas de diferentes altitudes, ele verificou que os valores do total de material orgānico deposi tado parecem refletir a biomassa dos ecossistemas - e indireta mente a produtividade - com maior sensibilidade que a fração foliar.

Há espécies cujas taxas de deposição de mater $\underline{i}$ al orgānico são superiores às de outras, sem que este aconteci mento seja motivado por caracterīsticas locais favoráveis. Se gundo ZAVITKOVISKI e NEWTON (1971), Alnus rubra e Ceanothus velutinus porporcionam taxas elevadas de deposição de material orgānico no noroeste dos Estados Unidos; ambas são fixadoras de $\mathrm{N}$ e ambas são espécies pioneiras na ocupação de terrenos 
pouco fērteis. Na opinião dos autores, os fatos sugerem que a produção de grandes quantidades de material orgānico decíduo pelas duas espécies, mesmo sob condições desfavoráveis, estā ligada à capacidade de fixar $N$.

\subsubsection{Característica do ecossistema florestal}

Dentro de características ambientais idēnticas ou similares, a natureza dos ecossistemas florestais e as prá ticas a eles aplicadas podem constituir fontes de variação das taxas de deposição de material orgānico.

\subsubsection{Plantações florestais versus florestas naturais}

Embora em pequeno nūmero, comparações realiza das têm demonstrado que, em uma mesma região, plantações flo restais podem apresentar taxas de deposição de material orgān co menores, iguais os maiores que as das florestas naturais.

Referindo-se a Chamaecyparis obtusa e Pinus den siflora, OHMASA e MORI (1937), citados em BRAY e GORHAM (1964), verificaram que as plantações destas espécies apresentaram ta xas de deposição de material orgānico superiores às de popula ções naturais.

Em dois locais da Costa do Marfim, BERNHARDREVERSAT (1975) comparou as taxas de deposição de material or gānico da floresta nativa e de plantações de Terminalia ivorensis, as quais possuiam idades de 22 a 38 anos. Verificou que em am bos os locais a deposição anual da plantação correspondeu a cer ca de $90 \%$ da deposição apresentada pela floresta.

$\mathrm{Na}$ India, em região temperada úmida montana, SAM RAJ et alii (1977) determinaram as taxas de deposição foliar da floresta nativa e de parcelas experimentais de Eucalyptus 
globulus e Acacia mearnsii, espécies indicadas para plantações na região. Obtiveram as mêdias anuais de $2,9,2,3 \mathrm{e} 1,3$ ton/ha para a floresta nativa, o eucalipto e a acácia, respectivamen te.

As comparações apresentadas baseiam-se em amos tragens efetuadas com bandejas. A inclusão de parcelas aproprí adas à mensuração de outras frações, como ramos grossos e cau les, é considerada essencial para estimar a deposição total re al.

3.5.3.2. Relações com a lotação e com a áreabasal

Segundo BRAY e GORHAM (1964), em povoamentos p $\underline{u}$ ros as taxas de deposição de material orgânico têm mostrado maior relação com a ārea basal de que com o nūmero de ārvores por hectares. Na Noruega, BONNEVIE-SVENDSEN e GJEMS (1957), ci tados pelos autores, constataram que a deposição de folhas foi de $70-75 \mathrm{~kg}$ por $\mathrm{m}^{2}$ de ärea basal, em povoamentos de coníferas e folhosas cujos valores situavam-se entre 8 e $40 \mathrm{~m}^{2} / \mathrm{ha}$,

Citando diversos exemplos, BRAY e GHORAM (1964) afirmam que quando um povoamento fechado é desbastado hā um de créscimo na deposição de material orgânico aproximadamente pro porcional ao grau de desbaste. REUKEMA (1964) e MILLER et alii (1976b) apresentaram dados acordantes a esta constatação, refe rentes a povoamentos de Pseudotsuga menziesii.

Como exemplificado por SVIRIDOVA (1960), hä cị cunstâncias em que a aplicação de um desbaste acarreta a eleva ção da capacidade produtiva local e, como consequéncia, da tá xa de deposição de material orgànico.

3.5.3.3. A adição e a retirada de nutrientes

E amplamente conhecido que a aplicação de ferti 
lizantes pode aumentar a produtividade de ecossistemas flores tais. Como demonstrado por HEILMAN (1961), MAKI (1961), DENEV (1976), GESSEL e TURNER (1976) e MILLER et alii (1976b), a adi ção de fertilizantes pode tambēm levar a acréscimo da quantida de de material orgâniço depositado.

Segundo BRAY e GORHAM (1964) a retirada da cama da de material orgānico do piso de florestas tem levado a de créscimo de produtividade, atribuídos principalmente à exporta ção de $N$. Obviamente, a redução da deposição de material orgāa nico é uma consequência provāvel desta prática.

\subsubsection{0 fator tempo}

0 tempo pode ser associado a 3 tipos distintos de, variação da deposição de material orgānico de um ecossiste ma florestal: a) variação estacional; b) variação entre anos, em um mesmo estágio seral; e c) variação entre estágios serais.

3.5.4.1. Variação estacional da deposição de mâ terial orgānico

A variação estacional da deposição de material orgānico é produto da interação entre a vegetação e o clima. Em geral, as folhas são o componente determinante das altera ções sazonais da deposição de material orgānico. Devido às me todologias utilizadas nos trabalhos científicos, o comportamen to de outros componentes não tem sido verificado com a precí são desejada.

BRAY e GORHAM (1964) apresentaram padrões de va riação estacional referentes a florestas situadas em diversas regiões do mundo. Outros exemplos para condições não tropicais foram fornecidos por TADAKI e KAGAWA (1968), CURLIN (1970), SYKES e BUNCE (1970), ZAVITKOVISKI e NEWTON (1971), GOSZ et alii 
(1972), LANG (1974) e SAMRAJ et alii (1977).

Em condições tropicais é comum, no decorrer de cada año, a intensificação da deposição de material orgānico na estação de menor precipitação, devido ao aumento do compo nente foliar. Resultados demonstrativos foram apresentados por MADGE (1965), KLINGE e RODRIGUES (1968a), ARAUJO (1970), FOURNIER e CAMACHO de CASTRO (1973), EGUNJOBI (1974) e GOLLEY et ali (1975).

Já no sēculo passado WARMING (1973, p. 220-231) registrara haver um āpice de deposição na estação seca, tanto nos cerrados propriamente ditos como nas matas ali existentes. RIZZO et alii (1971) apresentaram informações comprovatórias desta variação estacional em investigação realizada próxima a Goiānia, GO. Na Āfrica, HOPKINS (1966) e MALAISSE et alii (1975) verificaram idêntica tendência, em condições climáticas simila res às dos cerrados brasileiros.

As informações sobre plantações florestais bra sileiras são poucas. Em povoamento experimental de Eucalyptus saligna de 6 anos, em Piracicaba, SP, POGGIANI (comunicação pessoal) verificóu maior deposição de folhas no perīodo chuvo so, em contraste com o comportamento de vegetação nativa regio nal. Em plantação de Pinus óocarpa em ārea de cerrado em Agu dos, SP, POGGIANI (1978) constatou que dois terços das acīcu las cairam nos 6 meses mais secos e que em setembro e outubro, apontados como período final de seca e o início das primeiras chuvas, a queda das acículas foi mais acentuada.

SPECHT E BROUWER (1975) reuniram informações so bre a variação estacional da deposição foliar em povoamentos australianos. Observa-se a tendēncia de as espécies do leste da Austrālia - inclusive E. pilularis e E. maculata - apresen tarem deposição mais intensa nos meses de primavera e verão.

A variação estacional de outros componentes do 
material orgānico decĩduo não ē tão bem conhecida como o é para as folhas. Mc COLL (1966) e ASHTON (1975) apresentaram caracte rísticas da variação estacional de frações não foliares em flo restas de Eucalyptus maculata e Eucalyptus regnans, respectiva mente. KLINGE e RODRIGUES (1968a), TADAKI e KAGAWA (1968), GOSZ et alii (1972) e CHRISTENSEN (1975) forneceram informações a res peito da variação estacional de frações lenhosas e outras, em ecossistemas florestais distintos.

A ocorrēncia de fenōmenos metereolōgicos expres sivos pode acarretar consequēncias sobre distribuição sazonal da queda de material orgānico. BRAY e GORHAM (1964) indicaram vārios exemplos em que tempestades ocasionaram deposições inten sas de gravetos e ramos. Em povoamento de Eücalyptus saligna situado em Piracicaba, SP, POGGIANI (comunicação pessoal) con tatou intensa queda de folhas como consequéncia da geada severa ocorrida no inverno de 1975.

3.5.4.2. Variação anual da deposição de materi al orgânico

Em um mesmo ecossistema florestal pode ocorrer, de ano a ano, variações no total do material depositado e ou na intensidade de participação das frações. As variações são de correntes de aspectos cíclicos da comunidade ou motivadas por fatores de ordem climática ou biológica. Devido a estas possibi lidades, MEDWECKA-KORNAS (1971) considera adequado que o perīo do de observações sobre a queda de material orgānico de um ecos sistema florestal qualquer não seja inferior a 3 anos.

\subsection{Fatores cíclicos da comun $\underline{i}$ dade}

Ao cabo de 4 anos de observações em floresta de Quercus ilex, na Itālia, POLI et alii (1974) verificaram a exis 
tência de um ritmo bi-anual na queda de material orgānico.

$$
\begin{aligned}
& \text { 3.5.4.2.2. Fatores climáticos e biolō } \\
& \text { gicos }
\end{aligned}
$$

REUKEMA (1964) verificou, em 13 anos de observa ções em uma plantação de Pseudotsuga menziesii, que a proporção entre as quantidades anuais máxima e mínima de material orgāni co depositado foi de $3: 1$, e decorrente de condições climáticas.

Em 9 anos de observações em povoamentos de Alnus rubra, GESSEL e TURNER (1974) constataram a razão 2:1 entre as quantidades anuais máxima e mînima de deposição de material or gānico. A menor quantidade anual foi em 1956; em 1955 ocorreu um inverno extremamente severo que afetou a produção de folhas na estação de crescimento seguinte.

Em savana do Zaire, MALAISSE et alii (1975) ve rificaram, em 5 anos de investigações, que a relação entre as quantidades anuais máxima e mínima de deposição do componente "frutos" foi superior a 12:1. Segundo os autores, a produtivida de máxima, equivalente a 12 vezes a média dos 4 anos anteriores, foi motivada por condições climáticas favoráveis. BRAY e GORHAM (1964) e ASHTON (1975) tambēm apontaram a ocorrēncia de anos de frutificação intensa, em outros ecossistemas florestais.

Fatores não climáticos podem também ocasionar variações anuais marcantes. MORK (1942), citado por BRAY e GORHAM (1964), relata que um a taque de insetos resultou em va riação na deposição de material orgãnico por Picea abies.

\subsubsection{A influência do estágio seral}

0 pequeno número de pesquisas sobre o assunto e a falta da dados precisos sobre os componentes não foliares pre 
judicam o conhecimento da variação das taxas de deposição do ma terial orgânico entre estágios serais distintos. A anālise de informações contidas em NYE (1961), BRAY e GORHAM (1964), Mc COLL (1966), HURD (1971), ZAVITKOVSKI E NEWTON (1971), ASHTON (1975), EWELL (1976) e DUVIGNEAUD (1977, p. 103), permite supor que:

a) a fração foliar è a que mais rapidamente tor na-se estāvel; e

b) a deposição total real de material orgānico (incluindo partes lenhosas de todas as dimen sões) tende a aumentar com a sucessão vege tål, devido em grande parte à variação cor respondente do material lenhoso.

Segundo BRAY e GHORAM (1964), parece não haver tendēncia inerente ao aumento da taxa de deposição de material orgänico com a idade do ecossistema florestal, desde que as co pas estejam unidas e não haja alterações anormais das condições ambientais. Entretanto, os trabalhos consultados pelos autores adotaram a amostragem por bandejas e são deficientes quanto à amostragem de casca e material lenhoso. Deste modo, a afirmação deve ser entendida como referindo-se principalmente ao componen te foliar - ode maior importáncia em peso, nas bandejas - pelo que aproxima-se da generalização exposta no ītem (a) do parāgra fo anterior.

3.5.5. Taxas de deposição de material orgānico em ecos sistemas florestais

BRAY e GORHAM (1964) reuniram informações de to do o mundo sobre valores anuais de queda de material orgânico em ecossistemas florestais.

Resultados referentes a ecossistemas florestais em condições tropicais foram obtidos por NYE (1961), DOMMERGUES 
(1963), SETH et alii (1963), MADGE (1965), KLINGE e RODRIGUES (1968a), CORNFORTH (1970), EGUNJOBI (1974): GOLLEY et alii (1975), EWEL (1975), BERNHARD-REVERSAT (1976) e EDWARDS (1977).

HOPKINS (1966) obteve dados sobre floresta e sa vana, prōximas entre sī, na Nigéria. MALAISSE et alii (1975) in vestigaram a deposição de material orgânico em savana do Zaire.

AUSTRALIA (1966), MC COLL (1966), WEBB et alii (1969), ASHTON (1975) e SPECHT e BROUWER (1975) apresentaram da dos sobre eucaliptos em florestas australianas. Cozzo (1971), POGGIANI (1976) e SAMRAJ et alii (1977) determinaram taxas de deposição de material orgānico em plantações de eucaliptos, em locais distintos.

No Brasil, os conhecimentos sobre o assunto são escassos. ANDRADE (1940) e ANDRADE (1961, p. 387) fizeram men ções pouco detalhadas sobre a deposição de material orgānico em eucaliptais. KLINGE e RODRIGUES (1968a) obtiveram dados sobre floresta próxima a Manaus. POGGIANI (1976) e POGGIANI (1978) apresentaram informações sobre plantações de Eucalyptus saligna e Pinus oocarpa, respectivamente, no Estado de São Paulo. RIZZO et alii (1971) investigaram cerrado e mata próximos entre sí, nas cercanias de Goiānia, GO. HOMEM (1959) e BARROS e BRANDI (1975) destacaram a importância da deposição de material orgâni co de plantações florestais sobre caracterīsticas de solos de gradados, todavia sem fornecer taxas de deposição anual.

Informações sobre taxas de deposição de materi al orgānico em outros ecossistemas florestais, situados em cli ma näo tropical,foram fornecidos por DUVIGNEAUD e DENAYER-DE SMET (1970), SYKES e BUNCE (1970), AKAI E FURONO (1971), COZZO (1971), HURD (1971), COZZO (1972), ZAVITKOVSKI e NEWTON (1972), GOSZ et alii (1972), COZZO (1974), FOSTER (1974), GESSEL e TURNER (1974), LAMB e FLORENCE (1974), LANG (1974), POLI et alii (1974), PHILLIPSON et alii (1975), GESSEL e TURNER (1976), MILLER et alii 
(1976b) e TURNER et alii (1976).

\subsection{Fatores que a fetam a concentração de nutrientes do ma terìal orgãnìco decíduo.}

Considerando a deposição de material orgānico em seu ciclo anual, dois fatores são usualmente apontados como responsāveis por seus teores de nutrientes: as características de fertilidade quĩmica dos solos e as particularidades de nutri ção mineral das espēcies envolvidas. Pode-se pressupor, adicio nalmente, a influência do regime de chuvas, devido às quantida des expressivas de nutrientes passĩveis de serem. arrastados pe 1 a precipitação.

\subsubsection{A fertilidade dos solos}

Dentro de certos limites, as concentrações de nutrientes em tecidos vegetais vivos estão relacionadas de modo direto aos teores de nutrientes do solo. Estas relações tem gran de aplicação prática no campo florestal, através da utilização da anālise de tecidos como método diagnosticador do estado nu tricional das plantas.

Igualmente dentro de certos limites, as concen trações de nutrientes em estruturas decĩduas de uma espécie ou comunidade podem ser relacionadas de modo direto às caracterís ticas de fertilidade dos solos.

Em floresta tropical próxima a Manaus, KLINGE e RODRIGUES (1968b) verificaram que os nî́veis de $\mathrm{P}, \mathrm{K}, \mathrm{Ca}$ e $\mathrm{Mg}$ no material caído foram extremamente baixos, quando comparados com outras formações tropicais. O fato foi considerado como possi vel consequéncia de baixas concentrações no solo.

Em povoamentos de Pinus radiata de 30-40 anos, 
LAMB e FLORENCE (19.75) constataram, em determinadas épocas do ano, variaçóes significativas nos teores de $N$ e $P$ de aciculas decîduas. Os povoamentos com nî́veis inferiores de $N$ e $P$ apresen tavam elevadas porcentagens destes elementos imobilizados no pi so florestal, devido a taxas inferiores na decomposição da sera pilheira.

Resultados obtidos por HEILMAN (1961), MAKI (1961), DENEV (1975) e MILLER et alii (1976a) a testaram a influência da aplicação de fertilizantes sobre a concentração de nutrientes do material orgânico decî́duo.

A anālise de informações fornecidas por OVINGTON (1968), SPURR e BURTON (1973, p. 173) e HAAG et alii (1976) per mite supor que as variações de fertilitade do solo agem de modo mais intenso sobre as taxas de produção de biomassa e as taxas de transferência do ciclo biológico de nutrientes de uma dada comunidade florestal do que sobre as concentrações de nutrien tes de tecidos de suas ärvores.

\subsubsection{Espēcies}

Ārvores de espēcies diferentes pertencentes a um mesmo ecossistema ou a ecossistemas de condições edäficas se melhantes podem apresentar diferenças marcantes quanto a concen tração de nutrientes em suas estruturas verdes ou decĩduas. Exem plos referentes ao material orgânico decíduo podem ser constata dos em COILE (1937), SETH et alii (1963), GRUNERT (1966), GOSZ et alii (1972), TAPPEINER e ALM (1972), ASHTON (1975) e BER NHARD-REVERSAT (19.76).

3.7. Taxaș de restituição de nutrientes pela deposição de material orgânico.

As quantidades de nutrientes no ciclo anual da 
deposição de material orgânico são decorrentes da interação dos fatores abordados nos itens 3.5 e 3.6 .

DOMMERGUES (1963), KLINGE e RODRIGUES (1968) e GOLLEY et alii (1975, p. 76) apresentaram resultados comparati vos sobre florestas tropicais e näo tropicais. SETH et alii (1963), CORNFORTH (1970), BERNHARD-REVERSAT (1976) e EWELL (1976) exp seram valores sobre outros ecossistemas tropicais.

$$
\text { ATTIWILL (1968), WEBB et alii (1969) e ASHTON }
$$
(1975) mostraram dados sobre ecossistemas naturais de eucaliptos.

Os conhecimentos sobre formações brasileiras são escassos, destacando-se o trabalho de KLINGE e RODRIGUES (1968b) em floresta prōxima a Manaus. Quanto a plantações florestais, POGGIANI (1976) e POGGIANI (1978) apresentaram valores de depo sição anual por folhas em povoamentos de Eucalyptus saligna e Pinus oocarpa, respectivamente, no Estado de São Paulo.

Resultados referentes a outras florestas, de clima temperado, foram fornecidos por OVINGTON (1962, 1968), DUVIGNEAUD e DENAEYER-DE SMET (1970), GOSZ et alii (1972), FOSTER (1974), PATRICK e SMITH (1975), FLORENCE e LAMB (1975), GESSEL e TURNER (1976), MILLER et alii (1976b) e TURNER et alii (1976).

3.8. Aspectos da amostragem da deposição de ma terial orgâni $\underline{\text { co }}$

3.8.1. Sobre o local de amostragem

MEDWECKA-KORNAS (1971) recomenda que o local de amostragem deve ser tão uniforme quanto possível, e representa tivo de uma associação vegetal ou de uma unidade inferior, isto é, uma sub-associação ou facies. 0 autor pondera ser razoável restringị a dimensão da área em investigação para 1 ha de $100 x$ $100 \mathrm{~m}$; quando for necessārio medir a deposição de material orgâa 
nico em ārea maior ou mais heterogēnea, indica haver necessida de de dividī-la em partes menores, as quais devem ser conside radas separadamente.

\subsubsection{Sobre a adequação da amostragem}

Em artigo que trata especificamente de aspectos da metodologia para mensuração da deposição de material orgāni co, MEDWECKA-KORNAS (1971), seguindo proposição de OVINGTON e NEWBOLD (s.d.), julga que a amostragem deve ser suficiente pa ra levar o desvio padrão da média a um valor abaixo de $5 \%$ da média. Em sua investigação LANG (1974) também considerou es te nível de precisão como satisfatório.

Depreende-se de WILL (1959), KLINGE e RODRI GUES (1968a) e GOSZ et alii (1972) que é considerada satisfatō ria a amostragem cujo desvio padrão da média é inferior a $10 \%$ da média.

Como constataram KLINGE e RODRIGUES (1968a) p $\underline{0}$ dem ocorrer, para cada fração do materiál orgānico decíduo, a terações nas caracterīsticas de deposição em função da época do ano. Isto implica em que a amostragem deve ser suficiente para cobrir as variações estacionais.

3.8.3. Número e modo de disposição das parcelas de amos tragem

Segundo MEDWECKA-KORNAS (1971) o número de par celas deve ser relacionado à intensidade de amostragem, sendo conveniente um mínimo de 25-30 parcelas por hectare, devido a razões estatisticas. 0 autor indica que as parcelas podem ser dispostas sistematicamente ou ao acaso; entretanto, considera a disposição pelo método de "Golden Points", apresentado por 
ZUBRZYCKA (1960), como o mais apropriado. Por este método os pontos são locados no campo com o auxīlio de tabelas especiais. A vantagem atribuĩda ao método é que ele proporciona disposi ção das parcelas mais uniforme que a aleatorização, permitindo ainda a seleção de pontos adicionais na ārea experimental.

\subsubsection{Forma e tamanho das parcelas}

Tradicionalmente, a mensuração da deposição de material orgãnico é efetuada tendo bandejas de captação como parcelas; a ārea útil de cada bandeja situa-se, normalmente, entre 0,1 e $2 m^{2}$. Todavia, como verificado por KLINGE e Ro DRIGUES (1968a) e LANG (1974), frações distintas do material decīduo apresentam intensidades de variação distintas, quando amostradas por um único tipo de parcela. Esta constatação tem levado, paulatinamente, à instalação de parcelas particulares para cada fração ou grupo de frações.

\subsubsection{Folhas}

As folhas constituem a fração do material decí duo mais estudada quanto a amostragem.

\section{$3.8 \cdot 4 \cdot 1.1$. Forma}

Forma refere-se, neste trabalio, à configura ção da ārea de recepção do material decíduo apresentada pela parcela.

MEDEWCKA-KORNAS (1971) considera as parcelas de forma circular são preferíveis para qualquer fração, por reduzirem o efeito de borda.

Baseando-se em experimentos realizados em pop lações de conīferas e folhosas, SAITO e SHIDEI (1972) declara 
ram não haver diferença, quanto a fração foliar, entre bande jas circulares, quadradas ou trianguilares, de mesma ärea de cap tação. Os autores concluîram que são contra-indicadas bandejas retangulares cujo perīmetro seja superior a 1,4 vezes o períme tro de bandeja circular da mesma àrea.

Na prática as parcelas de forma quadradas são as mais empregadas. Considerando 22 trabalhos consultados que relatam detalhadamente a metodologia, verifica-se que em 17 foram utilizadas bandejas quadradas e em 1 a forma circular; nos outros 4 trabalhos não há indicação da forma de parcela.

\subsection{Tamanho}

Baseando-se em investigações comparativas rea lizadas na Polónia, MEDEWCKA-KORNAS (1971) considera que parce las de $0,100-0,125 \mathrm{~m}^{2}$ parecem adequadas para zonas temperadas.

Em florestas de folhosas no leste dos Estados Unidos, GOSZ et alii (1972) e LANG (1974) desenvolveram amos tragens que consideraram adequadas utilizando, respectivamente, parcelas de 0,224 e $0,67 \mathrm{~m}^{2}$. Os tamanhos de parcelas utilizados por HURD (1971), FOSTER (1974) e GESSEL e TURNER (1976) sitú am-se entre 0,18 e $0,25 \mathrm{~m}^{2}$.

POGGIANI (comunicação pessoal) e POGGIANI (1978) empregou bandejas de $1 \mathrm{~m}^{2}$ para a mensuração de queda de folhas em plantações de Eucalyptus saligna e de Pinus oocarpa, respec tivamente.

Trabalhos recentes em zonas tropicais, como os de CORNFORTH (1970), GOLLEY et alii (1975), BERNHARD-REVERSAT (1976) e EDWARDS (1977), foram efetuados a partir de bandejas quadradas de área igual ou superior a $1 \mathrm{~m}^{2}$. Entretanto, estudos comparativos entre tamanhos de parcelas não são conhecidos. 
3.8.4.2. Frações 1enhosas

A inclusão de amostragem em separado para fra ções lenhosas é recente, não sendo conhecidas investigações com parativas a respeito de formas e dimensões de parcelas.

GOSZ et alii (1972) instalaram parcelas quadra das de $4 \mathrm{~m}^{2}$, no piso da floresta, para coleta de ramos de diāme tro inferior a $10 \mathrm{~cm}$. Para mensuração de ramos mais grossos e de caules acima de $4 \mathrm{~cm}$ de diâmetro a intensidade de amostragem foi de $100 \%$ da àrea.

Em investigação realizada em savana do Zaire, MALAISSE et alii (1975) adotaram quadrados de $100 \mathrm{~m}^{2}$ para a men suração de ramos.

FURONO e YAMADA (1975) e GOLLEY et alii (1975) utilizaram quadrados de $4 \mathrm{~m}^{2}$ para a verificação de queda de ra mos.

\subsubsection{Cascas}

Na 1 i teratura consultada não hā informações so bre parcelas específicas para amostragem de cascas decíduas. Sem dūvida esta omissão terá levado a frequentes subestimativas da fração, devido ao fato de ela apresentar características prō prias de deposição. Como exemplo, Mc COLL (1976) e ASHTON(1975) observaram, em florestas de eucaliptos, que cascas decíduas 10 calizam-se nas proximidades imediatas das bases dos caules, e não de modo uniforme sobre o terreno.

3.8.4.4. Outras frações do material orgānico decíduo

Na literatura consultada não há referências so 
bre amostras específicas para as frações do material orgânico decíduo consideradas de menor importāncia quantitativa.

3.8.5. Frequência das coletas

Segundo MEDWECKA-KORNAS (1971) as coletas de vem ser mais frequentes quanto mais favoráveis à decomposição forem as condições ambientais. 0 autor recomenda que em flores tas temperadas a remoção deveria ser efetuada a períodos ideal de uma semana e máximo de 1 mês.

Em floresta tropical úmida prōxima a Manaus, STARK (1971) verificou a influencia de decomposição sobre o pe so do material orgânico depositado nas bandejas a partir de 5-7 dias apōs a deposição.

Consultando 23 trabalhos que mencionam os in tervalos de coleta, verifica-se que somente 4 efetuaram cole tas com perīodos inferiores a 1 mès e que 13 investigações fó ram efetuadas a partir de coletas mensais. 
4. MATERIAL E METODOS

4.1. Caracterização das āreas experimentais.

4.1.1. Localização, clima regional e topografia

A investigação foi realizada no municĩpio de Lençóis Paulista, SP, na Fazenda Rio Claro, de propriedade da Duraflora Silvicultura e Comércio Ltda.

$\mathrm{Na}$ Fazenda, de 12 mil hectares, as cotas alti tudinais situam-se mais frequentemente em torno de $670 \mathrm{~m}$, e am plitude é de 600-750m. As coordenadas geográficas do ponto central da propriedade são $22^{\circ} 48^{\prime} \mathrm{S}$ e $48^{\circ} 55^{\prime} \mathrm{W}$, aproximada mente. A vegetação primitiva dominante na região é o cerrado.

o tipo climático regional pelo sistema de Koeppen

é o Cwa. E um clima mesotérmico de inverno seco, em que a tem peratura média do mês mais quente ultrapassa $22^{\circ} \mathrm{C}$ e a do més mais frio é inferior a $18^{\circ} \mathrm{C}$, sendo as chuvas do més mais seco inferiores a $30 \mathrm{~mm}$.

Segundo SETZER (1966) a precipitação anual mé dia de Lençōis Paulista é próxima de $1200 \mathrm{~mm}$, predominando no semestre mais quente; os meses mais chuvosos são dezembro, ja neiro e fevereiro. A temperatura média anual é de $20,5{ }^{\circ} \mathrm{C}$, apro ximadamente; a média do més mais quente (janeiro) é da ordem 
de $24^{\circ} \mathrm{C}$, e a do més mais frio (julho) de $17^{\circ} \mathrm{C}$. A ocorréncia de geada é de 2 dias por ano, em média. Informações de GOLFa RI (1967) permitem estimar um déficit hídrico de $20 \mathrm{~mm}$, quando se calcula o balanço hỉdrico segundo Thornthwaite.

A Figura 1 expõe os totais mensais de precipi tação no período abrangido pelas operações de campo desta in vestigação. Os dados originais foram coletados em posto meteo rológico situado na sede da Fazenda, a $10 \mathrm{Km}$ das vegetações estudadas.

As observações foram realizadas em duas āreas contíguas: uma mata parcialmente explorada, denominada Matão, e uma plantação de eucaliptos, a qual constitui a Quadra 34 da Fazenda Rio Claro. A Figura 2 mostra a situação das duas vegetações; as Trilhas $1,2,3,4$ e 5 foram utilizadas para penetrações e observações ecológicas por CARPANEZZI (1975).

A Figura 3 informa sobre a declividade local. Nas Quadras 34 e 36 e em seus contactos com a mata a declivi dade é inferior a $3 \%$ em qualquer sentido, e somente acentuase no interior da mata, nas proximidades imediatas dos cursos d'água. 0 Rio Claro corre sobre leito de basalto e tem 10-20m de largura; a Água do Matão, riacho afluente do Rio Claro, tem ordinariamente $2-3 \mathrm{~m}$ de largura.

$$
\text { 4.1.2. Solos }
$$

0 eucaliptal situa-se sobre um Latossolo Verme Tho Amarelo fase arenosa. A Tabela 1 expõe os resultados de amostras compostas retiradas na ārea das medições, situada na Quadra 34 , a 200-300m da mata. As amostras foram coletadas em 1978.

Na parte inicial da mata, à margem do antigo cerrado, o solo é também um Latossolo Vermelho Amarelo fase arenosa. A Tabela 2 mostra os dados analiticos de uma trin cheira situada na Trilha 3 , a poucos metros no interior da ma ta. 
Nas regiões centrais da mata o solo foi classi ficado como Latossolo Vermelho Escuro textura mediana. A Tabe la 3 fornece as caracteristicas de uma trincheira aberta a $210 \mathrm{~m}$ do antigo cerrado, na Tritha 3.

Através da anāilise de amostras de solo ao lon go das Trithas, CARPANEZZI (1975) verificou a ocorréncia de um gradiente edáfico no corpo da mata, no sentido cerrado-cur so de água. A Figura 4 fornece um exemplo para alguns compo nentes de anālise de solos. Por seu exame torna-se evidente as condições de maior fertilidade das partes internas da mata.

\subsubsection{Matão}

Como indicado na Figura 2 o Matão é formado, atualmente, por duas partes principais, que correspondem a es tágios sucessórios distintos. A primeira é um capoeirão de cerca de 60 anos, originado do abandono de áreas agrīcolas em terreno desmatado. A outra, a mata propriamente dita, ocupa aproximadamente 150 ha e foi parcialmente explorada pelo sis tema de extração seletiva. Somente locais mais preservados das partes centrais da mata foram incluídos nesta investigação.

A Figura 2 mostra que a mata, com uma largura variável de 400-800m, é limitada pelos cursos de água e pelo eucaliptal; o eucaliptal substituiu a vegetação primitiva, um cerrado aberto. Fisionomicamente, a mudança de vegetação ce $\underline{r}$ rado-mata ocorria de maneira abrupta. Entretanto, caracteris ticas de cerrado podem ser detectadas pela composição em espé cies da faixa externa da mata, em pontos onde os sinais dequei ma são mais evidentes.

A faixa externa da mata limitrofe ao antigo cer rado tem cerca de $60-150 m$ de extensão e diferencia-se das par tes internas da mata pelo porte e pela composição em espécies. Em locais preservados de fogo e de derrubadas, sua fisionomia é semelhante à das partes internas, porém com porte inferior. 


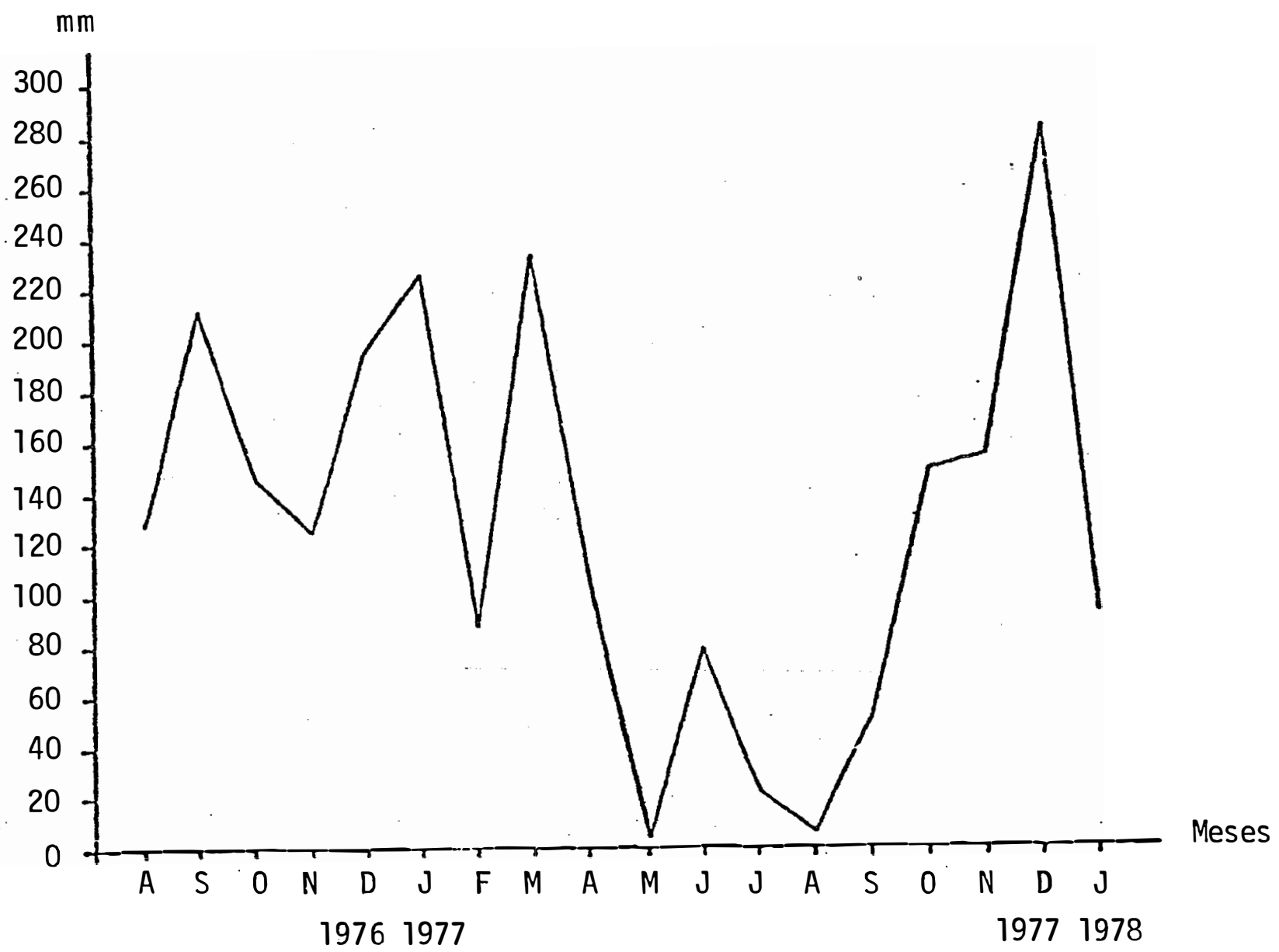

Fig. 1. Precipitações mensais na sede da fazenda Rio Claro, no perĩodo das coletas 


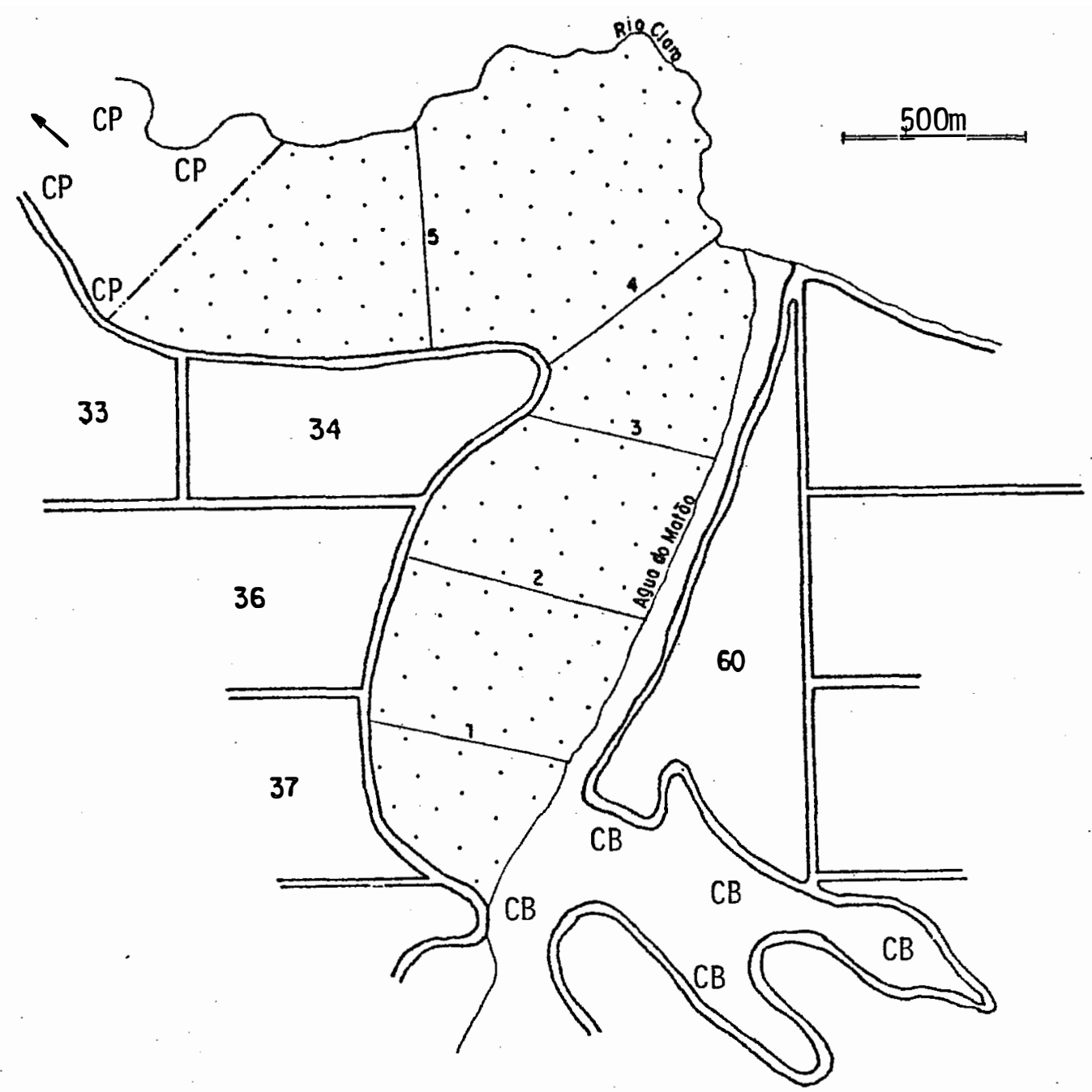

Fig. 2. Mapa de situação da mata e do eucaliptal

CB Capoeiras e banhados

$C P$ Capoeirão

$\because$ Mata parcialmente explorada

Estradas

1,2,3,4 e 5 - Trilhas de penetração e observação 33,34,36,37 e 60 - Quadras de plantação de eucaliptos 


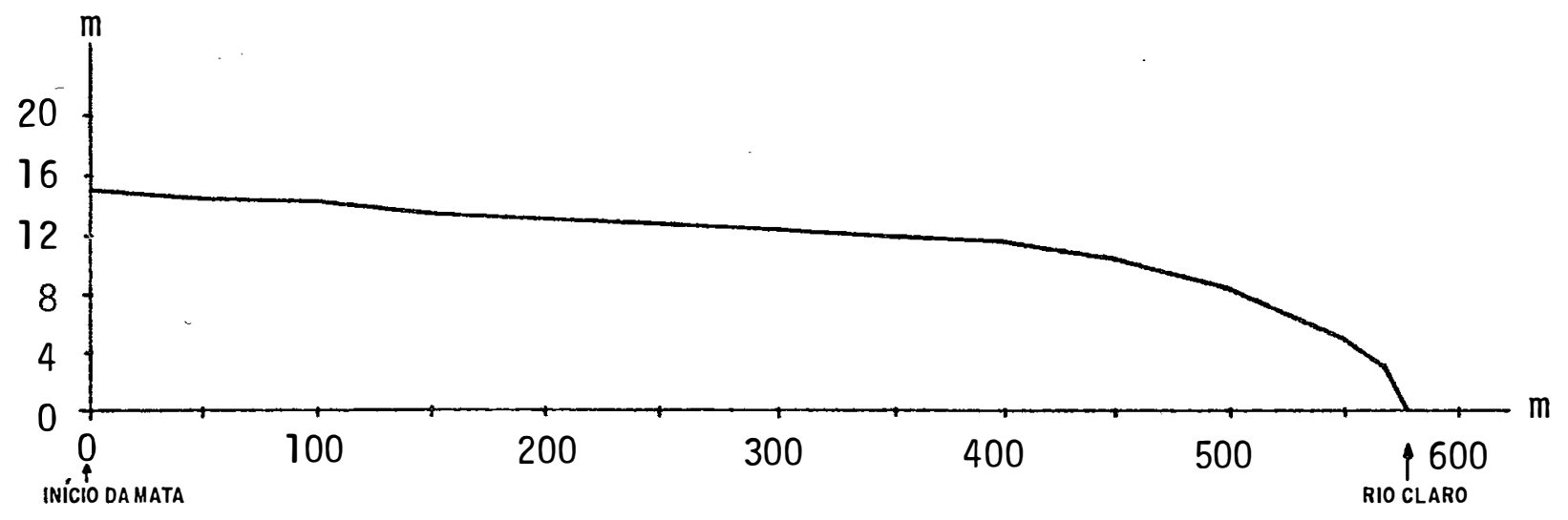

Fig. 3. Declividade da Trilha 5 em relação ao Rio Claro

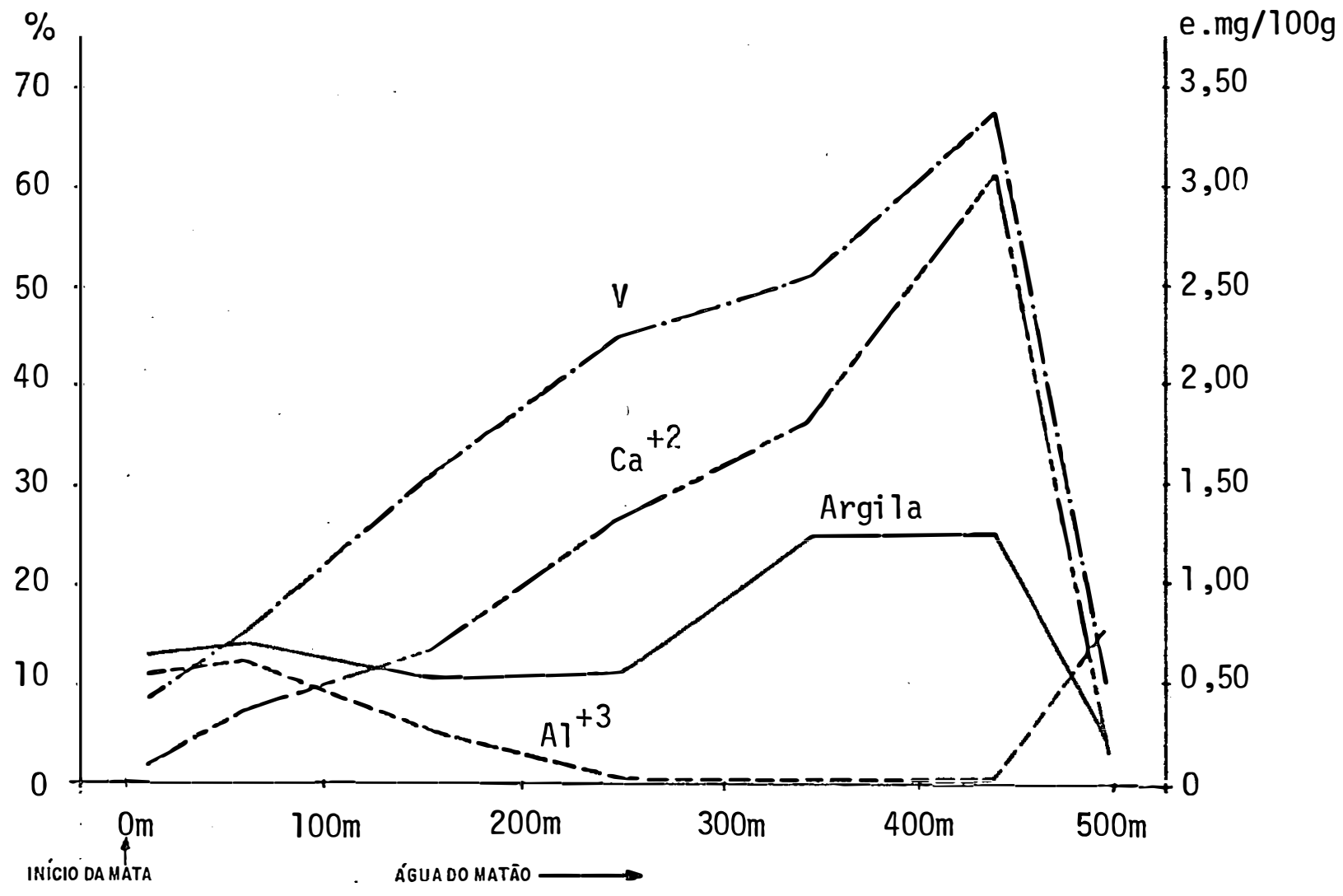

Fig. 4. Variação de caracterīsticas edāficas ao longo da Trilha $1, \bar{a}$ profundidade de $30 \mathrm{~cm}$ ( $\mathrm{V}$ e argila em $\%, \mathrm{Ca}^{+2}$ e $\mathrm{Al}^{+3}$ em e.mg/100g) 
Tabela 1. Dados de anālise de solo de amostras compostas tomadas no eucailiptal

\begin{tabular}{|c|c|c|c|c|c|c|c|c|c|c|}
\hline \multirow{2}{*}{$\begin{array}{l}\text { Prof und idade } \\
\qquad(\mathrm{cm})\end{array}$} & \multicolumn{3}{|c|}{ Anālise Mecânica $(x)$} & \multicolumn{6}{|c|}{ Ions trocāveis (e. mg/100 a ) } & \multirow{2}{*}{$\begin{array}{c}\mathrm{pH} \\
(\text { ägua } 1: 1)\end{array}$} \\
\hline & Areia & Limo & Argila & $\mathrm{Ca}^{++}$ & $\mathrm{Mg}^{++}$ & $\mathrm{K}^{+}$ & $\mathrm{PO}_{4}=$ & $\mathrm{H}^{+}$ & $\mathrm{Al}^{+++}$ & \\
\hline 20 & 80,7 & 6,2 & 13,1 & 0,20 & 0,10 & 0,05 & 0,02 & 3,20 & 0,96 & 5,1 \\
\hline 40 & 82,5 & 4,0 & 13,5 & 0,16 & 0,08 & 0,08 & 0,02 & 2,88 & 0,88 & 5,2 \\
\hline 80 & 81,2 & 2,8 & 16,0 & 0,16 & 0,08 & 0,03 & 0,01 & 2,72 & 0,88 & 5,3 \\
\hline 120 & 80,1 & 2,6 & 17,3 & 0,16 & 0,08 & 0,02 & 0,01 & 2,40 & 0,80 & 5,3 \\
\hline 180 & 77,7 & 3,4 & 18,9 & 0,16 & 0,08 & 0,02 & 0,01 & 2,24 & 0,64 & 5,5 \\
\hline
\end{tabular}

Tabela 2. Dados de anālise de solo de uma trincheira aberta na Trilha 3 , a $4 \mathrm{~m}$ do antigo cerrado

\begin{tabular}{|c|c|c|c|c|c|c|c|c|c|c|c|c|}
\hline \multirow{2}{*}{$\begin{array}{l}\text { Profundi dade } \\
\text { (cm) }\end{array}$} & \multicolumn{3}{|c|}{ Anālise Mecānica (\%) } & \multirow{2}{*}{$\begin{array}{c}\text { C T C } \\
(e . m g / 100 g)\end{array}$} & \multicolumn{6}{|c|}{ Ions trocāveis (e.mg/100g) } & \multirow{2}{*}{$\begin{array}{c}\mathrm{pH} \\
\text { (ăgua } 1: 1 \text { ) }\end{array}$} & \multirow{2}{*}{ V\% } \\
\hline & Areia & Limo & Argila & & $\mathrm{Ca}^{++}$ & $\mathrm{Mg}^{++}$ & $k^{+}$ & $\mathrm{PO}_{4}=$ & $\mathrm{H}^{+}$ & $\mathrm{Al}^{++}$ & & \\
\hline $0-15$ & 80,9 & 4,0 & 15,1 & 5,71 & 0,21 & 0,08 & 0,14 & 0,01 & 0,49 & 0,96 & 4,2 & 8,6 \\
\hline $16-35$ & 79,3 & 4,3 & 16,4 & 3,57 & 0,13 & $=$ & 0,03 & - & 0,34 & 0,78 & 4,2 & 4,5 \\
\hline $36-80$ & 77,9 & 4,9 & 17,2 & 2,93 & 0,16 & $\div$ & 0,01 & - & 0,52 & 0,67 & 4,3 & 6,5 \\
\hline $81-120$ & 74,4 & 5,0 & 20,6 & 2,78 & 0,14 & - & 0,01 & - & 0,52 & 0,62 & 4,4 & 5,7 \\
\hline
\end{tabular}

Tabela 3. Dados de anālise de solo de uma trincheira aberta na Trilha 3 , a $210 \mathrm{~m}$ do antigo cerrado .

\begin{tabular}{|c|c|c|c|c|c|c|c|c|c|c|c|c|}
\hline \multirow{2}{*}{$\begin{array}{l}\text { Profundidade } \\
\text { (cm) }\end{array}$} & \multicolumn{3}{|c|}{ Anālise Mecānica (\%) } & \multirow{2}{*}{$\begin{array}{c}\text { C T.C } \\
\text { (e.mg/ } / 100 \mathrm{~g})\end{array}$} & \multicolumn{6}{|c|}{ Ions trocāve is $(\mathrm{e} \cdot \mathrm{mg} / 100 \mathrm{~g})$} & \multirow{2}{*}{$\begin{array}{c}\mathrm{pH} \\
\text { (ägua } 1: 1 \text { ) }\end{array}$} & \multirow{2}{*}{ V\% } \\
\hline & Areia & Limo & Argila & & $\mathrm{Ca}^{++}$ & $\mathrm{Mg}^{++}$ & $\mathrm{K}^{+}$ & $\mathrm{PO}_{4}=$ & $\mathrm{H}^{+}$ & $A 1^{+++}$ & & \\
\hline $0-30$ & 76,8 & 10,4 & 12,8 & 5,10 & 0,83 & 0,45 & 0,09 & 0,01 & 0,25 & 0,37 & 4,4 & 27,4 \\
\hline $31-50$ & 67,6 & 7,2 & 25,2 & 4,72 & 1,07 & 0,77 & 0,05 & 0,01 & 0,32 & 0,22 & 4,7 & 41,7 \\
\hline $51-100$ & 63.? & 6,3 & 30,4 & 5,39 & 0,96 & 1,04 & 0,02 & 0,01 & 0,33 & 0,26 & 4,8 & 38,6 \\
\hline $100-130$ & 59,6 & 8,0 & 32,4 & 4,39 & 0,24 & 0,38 & 0,05 & 0,01 & 0,65 & 1,01 & 4,6 & 15,7 \\
\hline
\end{tabular}


Espécies típicas destes locais da faixa externa são copaíba (Copaifera Zangsdorfii), maçaranduba (Persea cordata), cane lão fétido (Nectandra sp), ipé tabaco (Zeyhera tuberculata), ipē roxo (Tabebuia sp), jacarandā paulista (Machaerium vizlo sum) e amendoim do cerrado (Platipodium elegans). As espécies das partes mais internas da mata são outras, indicadas adian te. Poucas espécies - como peroba rosa (Aspidosperma polyneu ron), canjarana (Cabralea sp) e jequitibá (Cariniana estrellen sis) - são comuns a ambas as situações.

A presença de grupos de espécies próprias de ca da parte da mata parece associada ao gradiente de condições edáficas, exemplificado na Figura 4. A disponibilidade de água no solo como possível fator regulador da distribuição das es pécies merece ser ressaltada. Segundo RIZZINI (1979, p. 70-90), diversas espécies comuns na parte externa da mata são indica tivas de menor disponibilidade de água. Realmente, o solo da parte externa apresenta, em relação ao centro da mata, menor teor de argila (Tabelas 2 e 3 ) e sua cota em relação ao curso d'água é maior, como pode ser deduzido da Figura 3.

Excluîda a faixa de mata limîtrofe ao cerrado, as caracterīsticas dos locais internos não atingidos pela ex tração seletiva conduzem às classificações de "mata subtropi cal do leste e sul do Brasil" proposta por HUECK (1972, p. 186), ou "floresta latifoliada tropical" segundo ROMARIZ (1974, p. 9). RIZZINI (1979, p. 73) classifica a vegetação como "flores ta atlāntica pluvial ripária".

Em linhas gerais, a mata não tocada apresentase como floresta latifoliada semicaducifólia, com altura do estrato dominante de 25-30m, e densidade moderada de lianas e epîfitas. Eventualmente, ārvores de cabreúva (Myroxilum balsa mum) e peroba rosa (Aspidosperma polyneuron) atingem alturas próximas a $35 \mathrm{~m}$. Os diāmetros à altura do peito (DAP) de pero ba rosa, a espécie comercializável mais abundante, alcançam até $130 \mathrm{~cm}$. 
CARPANEZZI (1975) efetuou levantamento sócioecológico de regiões preservadas do interior da mata, aplican do o método descrito por MEGURO (1973, p. 80-83). Foram utili zadas 18 parcelas de $300 \mathrm{~m}^{2}$ e medidos os diāmetros de todos os indivíduos acima de $4 \mathrm{~m}$ de altura. Foram constatadas 79 espē cies arbóreas conhecidas pelo mateiro por nomes vulgares. A ārea basal média foi de $69,5 \mathrm{~m}^{2} / \mathrm{ha}$, com extremos de 41,0 e $105,4 \mathrm{~m}^{2} / \mathrm{ha} ;$ a faixa de valores mais frequentes foi de 60-70 $\mathrm{m}^{2} / \mathrm{ha}$. A Tabela 4 apresenta os resultados concernentes as prin cipais espécies identificadas botanicamente; inclui, também, espécies do estrato dominado conhecidas apenas por nomes vul gares.

A espēcie de maior īndice de Importāncia na ma ta é carrapateiro branco, uma Rutaceae, provavalmente do géne ro Metrosideros, a qual ocupa os estratos dominado e interme diārio. E uma espécie de ampla distribuição na mata, com gran de número de indivî́duos, porém com diāmetros não elevados, ra ramente acima de $20 \mathrm{~cm}$.

A participação expressiva de peroba rosa (Asp $\underline{i}$ dosperma polyneuron), indicada na Tabela 4, encontra apoio em FACCHINI (1970), que afirmou que matas semelhantes permitiam a extração de até $400 \mathrm{~m}^{3}$ por alqueire de toras desta espécie.

Espēcies de madeiras apreciadas localmente, co mo cedro (Cedrela sp), cabreúva (Myroxilum balsamum), sobra sil amarelo (Colubrina rufa) e araribā (Centrolobium sp) en contram-se sem dūvida subestimadas, devido à extração seletị va de que foram alvo em épocas passadas.

outras espécies arbóreas presentes nas partes centrais da mata, mas que não aparecem na Tabela 4, por serem naturalmente mais raras em áreas preservadas do Matão, são ca biūna (Machaerium scleroxylon), canafístula (Peltophorum voge lianum), amendoim do mato (Cassia ferruginea), taiūva (Cloro phora tinctoria), tamboril (Entorolobium contortisiliquum), ja 
Tabela 4. Características das principais espēcies das partes preservadas da mata $\underline{G}^{\prime}$

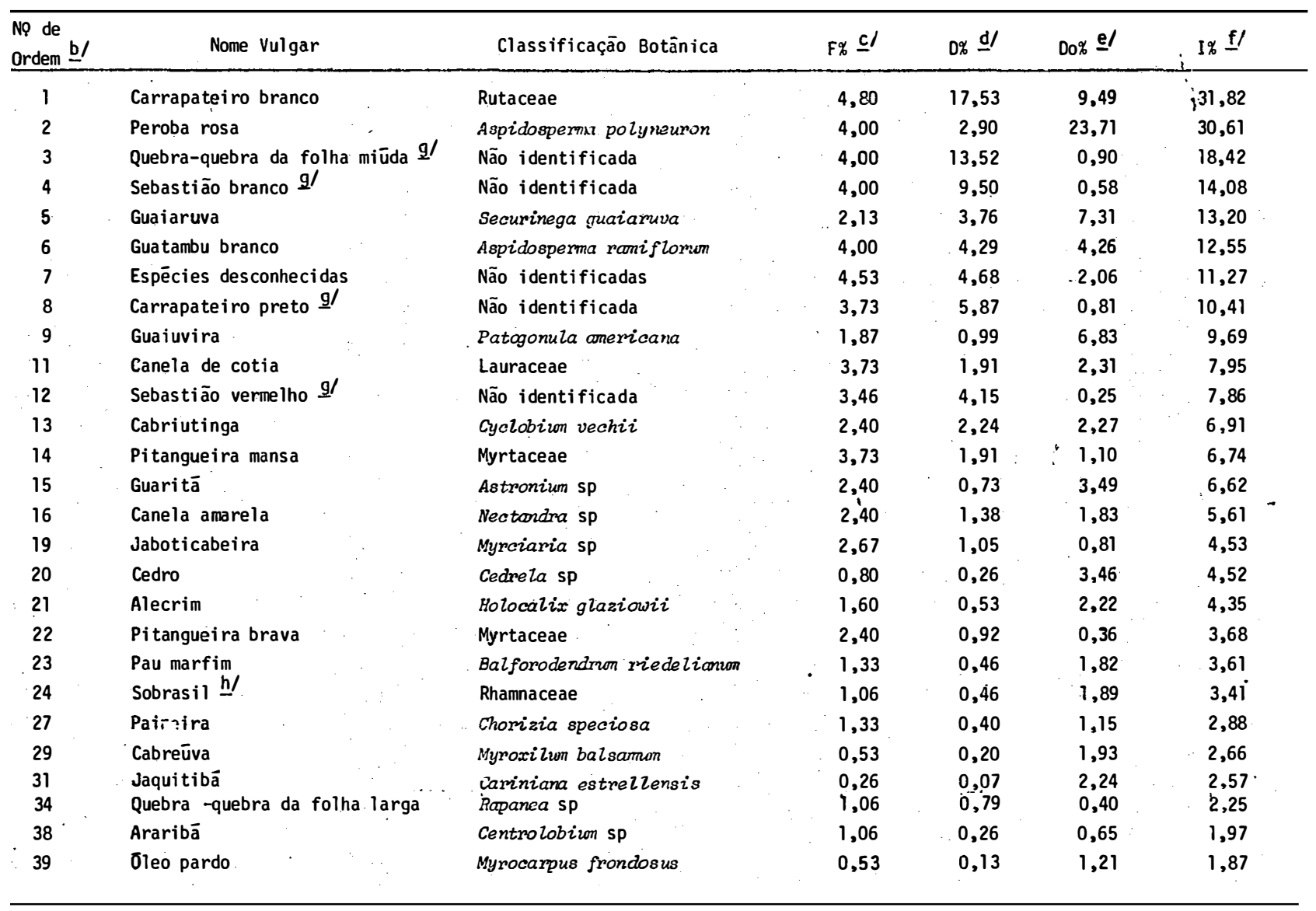

af Segundo metodologia proposta por MEGURO (1973); dentre as espécies conhecidas somente pọr nome vul gar, estão incluĩdas apenas algumas do estrato dominado, devido ao alto valor de I

b/ Função de valores decrescentes de I de todas as espécies encontradas

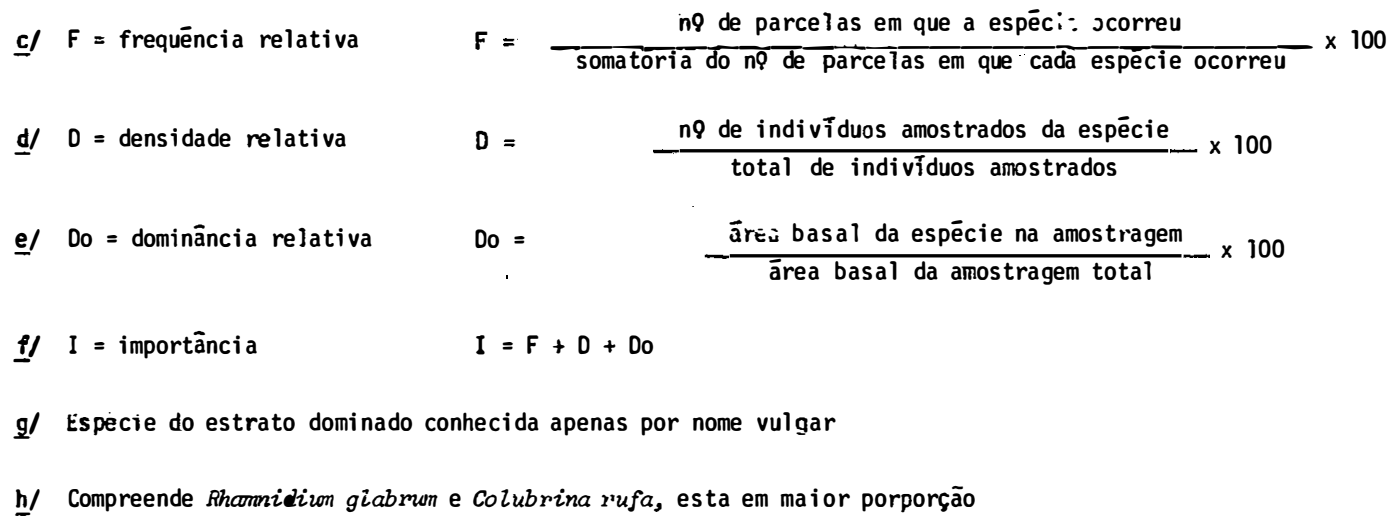


racatiá (Jaracatia dodecaphylıa) e pau jacarē (Piptadenia co munis).

\subsubsection{0 eucaliptal}

A Quadra 34 da Fazenda Duraflora tem ārea de $23,95 \mathrm{ha}$. 0 espaçamento original desejado era de $3 \times 2 \mathrm{~m}$. Foi plantada com Eucalyptus saligna Smith e replantada com Eucalyp tus grandis Hill ex Maiden, sendo utilizadas mudas provenien tes de sementes coletadas em Mairinque, SP, e Coffs Harbour, Nova Gales do Sul, Austrālia, respectivamente. 0 plantio foi efetuado em outubro de 1972 e o replantio, de $41,4 \%, 2$ meses após.

A vegetação original era um cerrado aberto. Pa ra o plantio foram efetuadas calagem com calcário dolomítico na razão de 2 ton/ha, e adubação, tendo sido aplicados $400 \mathrm{~kg} /$ ha de fertilizante contendo $N$, P e K na proporção 10:34:6, res pectivamente.

Um censo populacional da Quadra 34, realizado em setembro de 1977, revelou uma porcentagem de falhas de $6,66 \%$ e uma porcentagem de árvores mortas de $0,37 \%$, calculadas em relação ao número real de covas ( 1615 covas por hectare). Ao final de 1976, que corresponde ao inīcio das medições da pre sente investigação, a altura média e a área basal eram, res pectivamente, $16,1 \mathrm{~m}$ e $18,0 \mathrm{~m}^{2} / \mathrm{ha}$. Previa-se que 0 incremento médio anual seria próximo a $50 \mathrm{st} / \mathrm{ha}$ na ocasião do corte, ao final de 1978.

\subsection{Material}

Para a amostragem da deposição de material or gānico foram empregadas bandejas quadradas, com ārea de recep ção de $1 \mathrm{~m}^{2}$, construĩdas em madeira e tela plástica tipo mos quiteiro. No campo as superfícies de recepção distavam cerca de $40 \mathrm{~cm}$ do solo. 


\subsection{Métodos}

\subsubsection{Distribuição das bandejas}

Em uma ārea de $100 \times 100 m$ do eucaliptal da Qua dra 34 foram distribuídas ao acaso 25 bandejas.

$\mathrm{Na}$ parte interna da mata as bandejas foram colo cadas ao acaso em locais considerados representativos da vege tação não tocada, escolhidos a partir dos conhecimentos obti dos por CARPANEZZI (1975).

Foram escolhidos 7 locais e em cada local foram colocadas 7 bandejas, distribuídas por uma ārea de $3600 \mathrm{~m}^{2}$ (60x $60 \mathrm{~m})$. 0 total máximo possīvel de cada coleta era, pois, de 49 bandejas. Em cada coleta, a reunião dos dados de deposição de material orgānico de todas as bandejas, sem distinção por 10 cal, foi considerada como representativa da mata.

\subsubsection{Período e frequência das coletas}

0 perīodo de coletas estendeu-se de outubro-no vembro de 1976 a janeiro de 1978. Foram realizadas 16 coletas na mata e 15 no eucalipta 1 , a intervalos próximos de 30 dias.

\subsubsection{Processamento do material coletado}

Apōs transferido para sacos plásticos ou de pa pel Kraft com identificação da bandeja, o material de cada co leta era transportado a Piracicaba e submetido a uma série de operações.

\subsubsection{Secagem preliminar}

Quando necessário, o material recém-chegado era submetido a uma secagem preliminar para retirar o excesso de umidade.

\subsubsection{Separação em frações}

0 material de cada bandeja era separado manual 
mente em 3 frações: folhas (incluindo foliolos), ramos (corres pondente a partes lenhosas arbōreas de todas as dimensões) e miscelànea (englobando todo o restante).

\subsubsection{Secagem definitiva e pesagem}

As frações de cada bandeja eram submetidas a se cagem em estufa a $80-85^{\circ} \mathrm{C}$ até peso constante, e a seguir pesa das com precisão de $0,1 \mathrm{~g}$.
4.3.3.4. Amostragem e moagem para anālise quĩ mica

Apōs pesagem individual, o total de cada fração era reunido e homogeneizado, sendo retiradas 4 amostras para anālise quĩmica. Estas amostras eram moídas em moinho tipo Willey, com malha de 20 mesh, e o material resultante levado para a análise quîmica.

\subsubsection{Anāilise quĩmica}

As determinações de $N$ e $P$ foram efetuadas no La boratōrio de Hidrologia e Ecologia do Curso de Engenharia Flo restal da ESALQ; $\mathrm{K}$, Ca e Mg foram determinados no Laboratório no Setor de Nutrição Mineral de Plantas, do Departamento de Quĩmica da ESALQ.

Os nutrientes $\mathrm{Ca}$ e $\mathrm{Mg}$ foram determinados em es pectrofotōmetro de absorção atómica; $\mathrm{P}$ em fotocolorīmetro; $\mathrm{K}$ em fotōmetro de chama e $\mathrm{N}$ por titulação ácida após passagem por microdestilador de Kjeldah. As sequéncias operacionais fo ram conforme SARRUGE e HAAG (1974). 


\section{RESULTADOS}

A Figura 5 apresenta as taxas de deposição de ma terial orgânico na mata, em cada uma das coletas. As folhas constituiram a fração dominante nas bandejas, com um ápice de deposição compreendido entre julho e novembro, aproximadamente. Em geral, as frações ramos e miscelānea apresentaram, em cada coleta, variabilidade maior que a fração foliar. As fra ções ramos e miscelānea apresentaram a mesma tendēncia de va riação estacional, com perīodo de maior deposição compreendido entre setembro e janeiro, aproximadamente.

A Figura 6 revela que também no eucaliptal as fo Ihas constituiram a fração dominante e que as frações ramos e miscelānea apresentaram variabilidade acentuada em cada coleta. A deposição foliar foi mais intensa no período de dezembro a março, com um pico isolado na parte central do ano. A deposi ção das frações ramos e miscelānea foi maior em ocasiões do pe rĩodo chuvoso.

A Figura 7 mostra que na fração foliar da mata a concentração de $K$ apresentou oscilações notáveis no decorrer das coletas. Outros elementos considerados móveis, como o $\mathrm{N}$ e o $P$, não apresentaram variação concordante com a do K.Observa-se, 
em todas as coletas, a tendência à sequência $C a \geqslant N>K>M g>P$, quan to à concentração de nutrientes.

Como mostra a Figura 8 , as concentrações de nu trientes na fração foliar do eucaliptal foram bastante inferio res às da mata. Como na fração foliar da mata, não se pode as sociar a variação do $K$ com as de $N$ e $P$. Observa-se, nas cole tas, a sequēncia $\mathrm{N}>\mathrm{Ca}>\mathrm{Mg} \geqslant \mathrm{K}>\mathrm{P}$.

A Tabela 5 evidencia, numericamente, que no pe ríodo anual as concentrações de nutrientes no material decíduo da mata foram muito superiores às do eucaliptal, que no total, quer na comparação fração com fração.

A Tabela 6 apresenta as quantidades de material orgânico e nutrientes depositadas no período anual, na mata e no eucaliptal. Em ambos os ecossistemas as folhas foram as fra ções medidas com maior precisão. Considerando a sobreposição de valores de média \pm desvio padrão da média, as quantidades de folhas e do total de material orgânico foram maiores na mata. As quantidades de nutrientes depositadas na mata são maiores que as depositadas no eucaliptal.

Os valores anuais apresentados nas Tabelas 5 e 6 foram calculados a partir de dados de coletas realizadas no pe rĩodo de dezembro de 1976 a dezembro de 1977. 

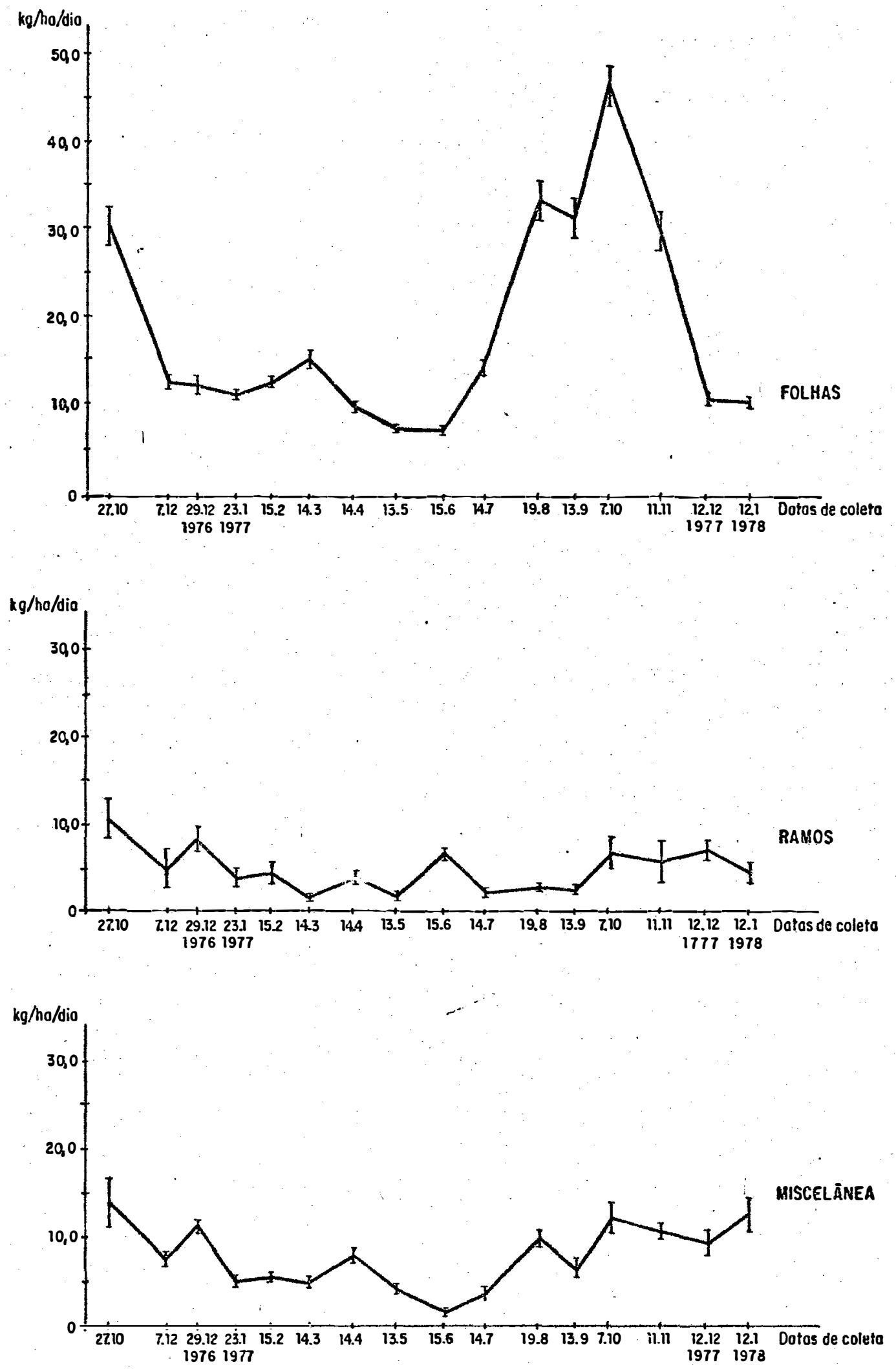

FIG.5. Taxas de deposiçāo de material orģ̋̂nico no moto

(média Idesvio padrōo da média) 

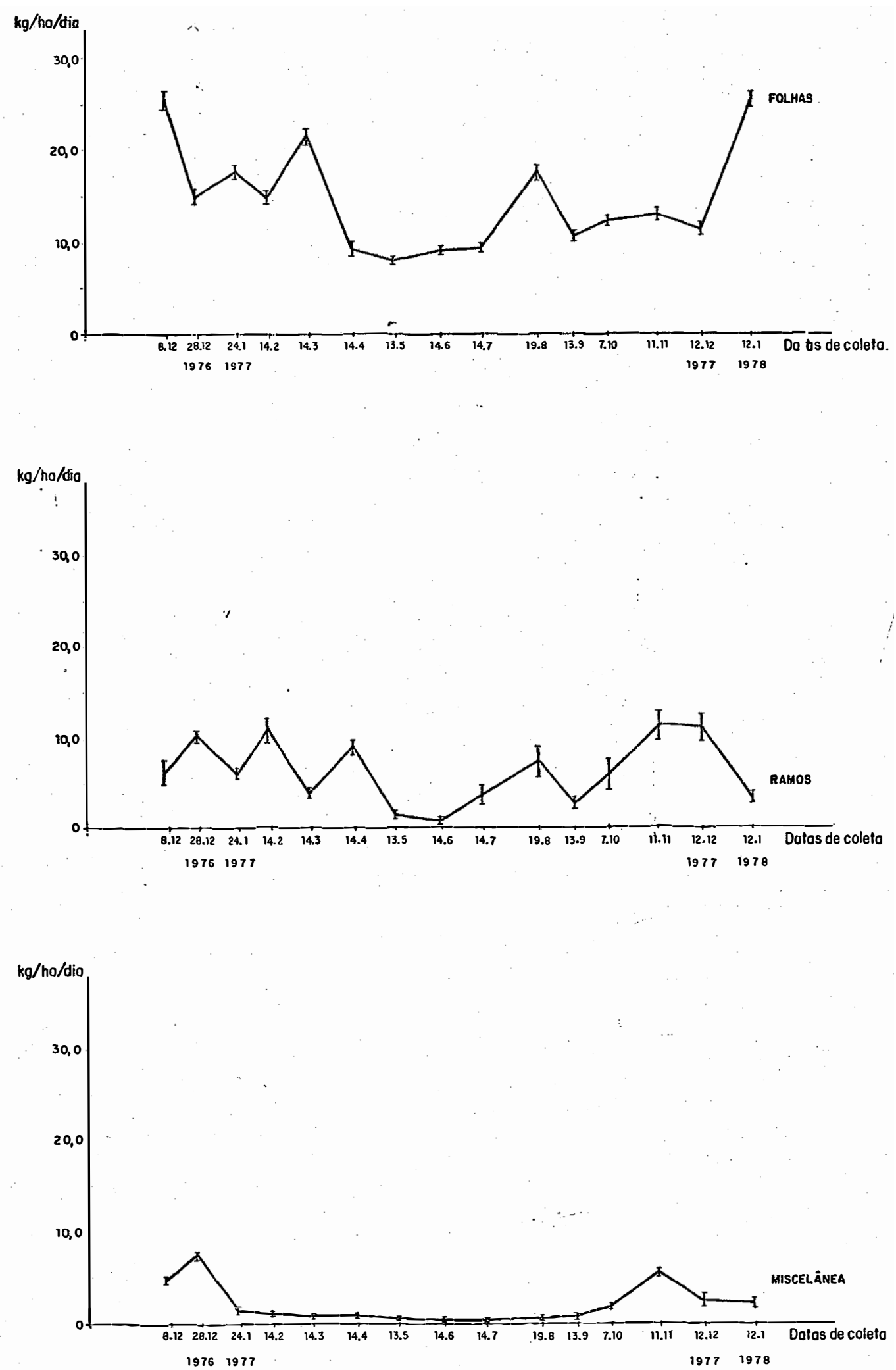

FIG.6. Taxas de deposiçōo de mołeriol orgânico no eucaliptal (médio I desvio podrōo do médio) 

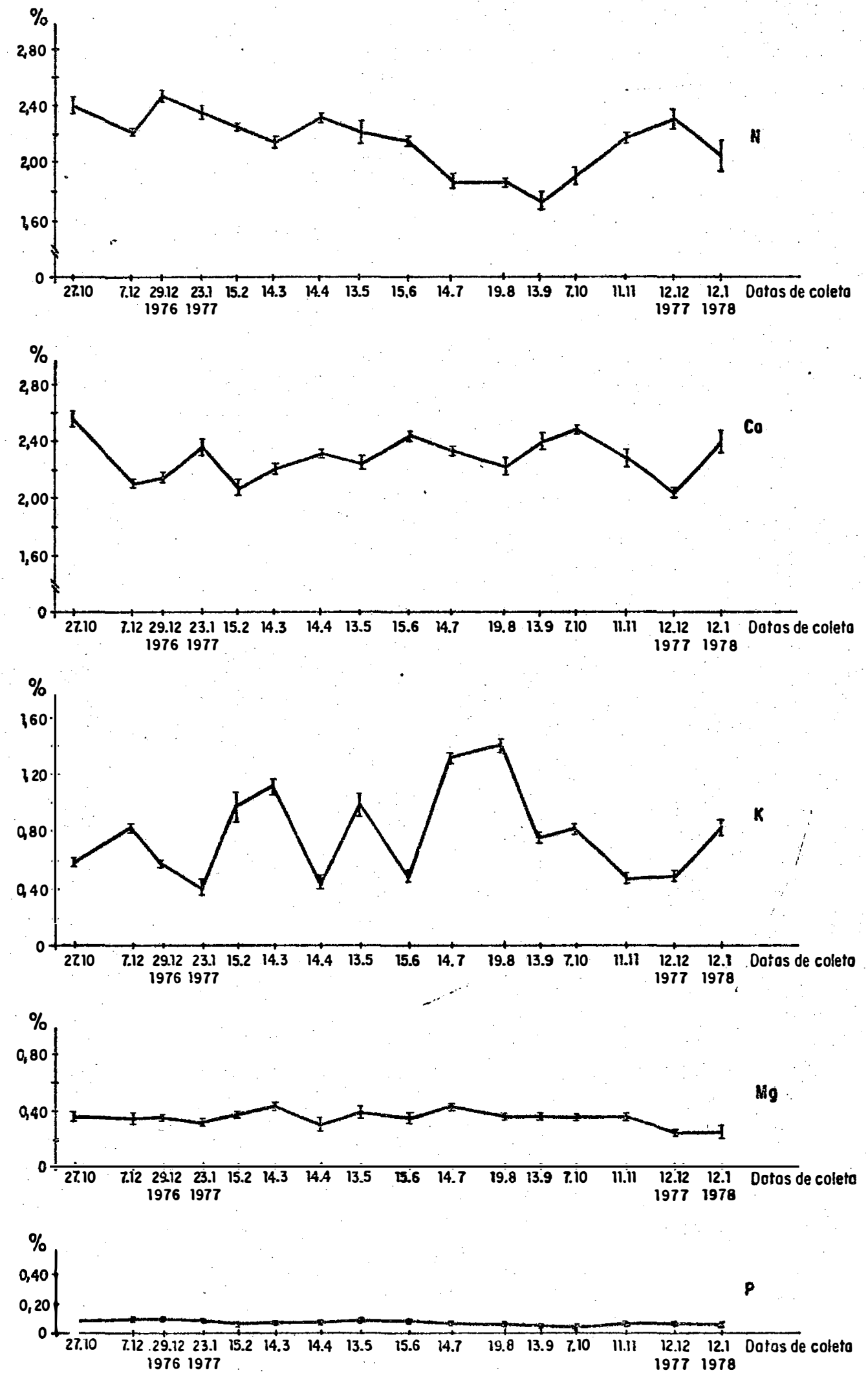

FIG.? Concentraçōes de nutrientes nas folhas deciduas da mata (médio £desvio padrāo da média) 

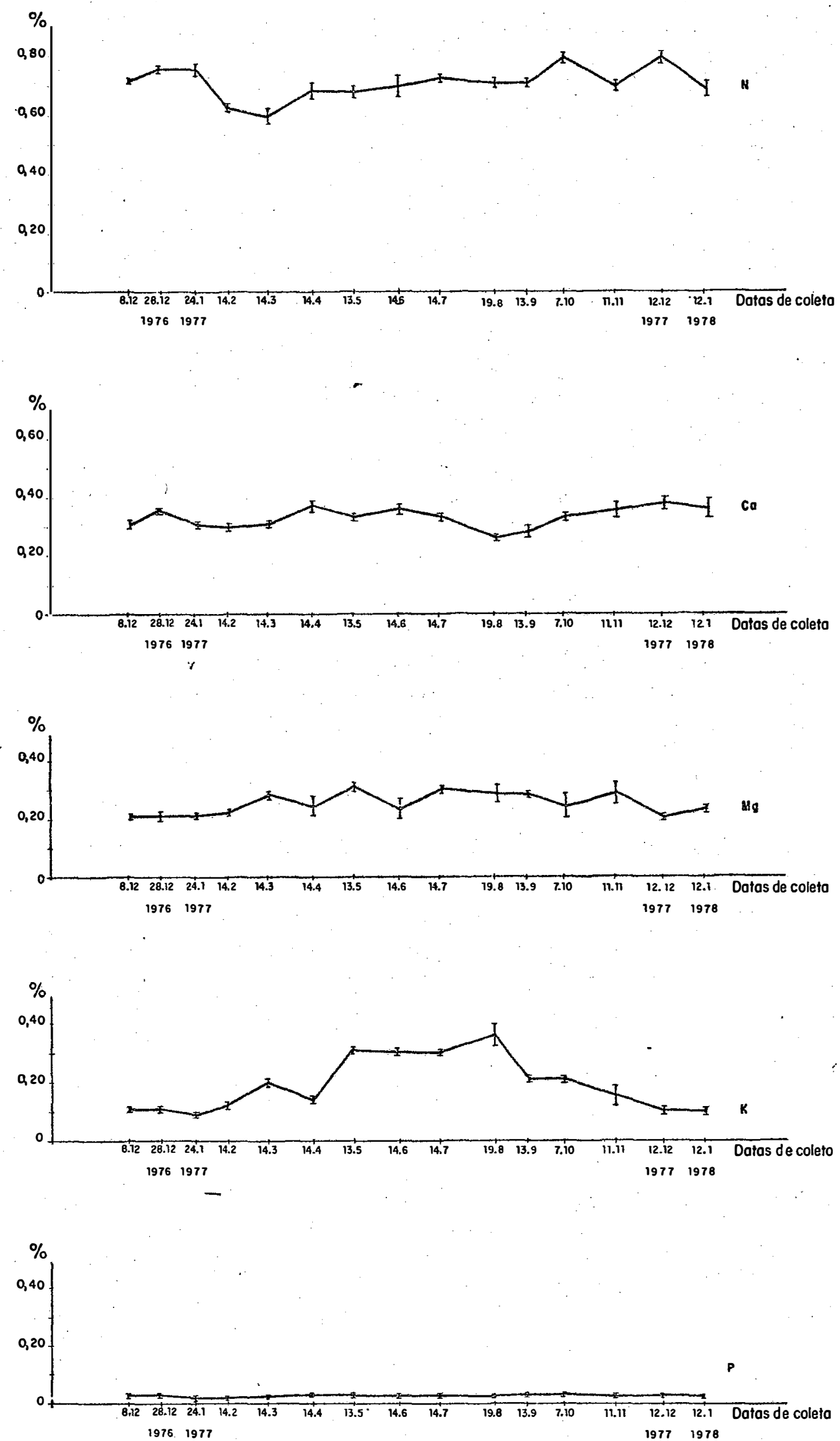

FIG.8. Concentraçōes de nutrientes nas folhas decíduas do euccliptal (média \pm desvio padrōo da média) 


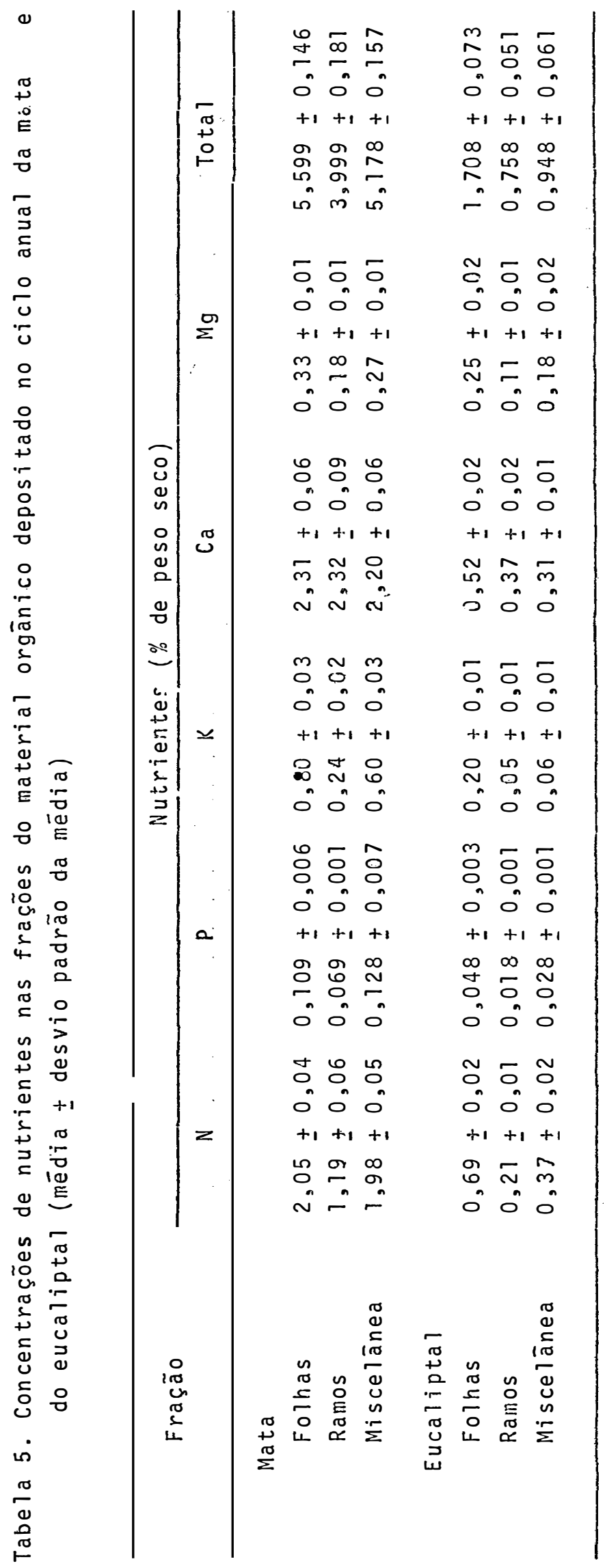




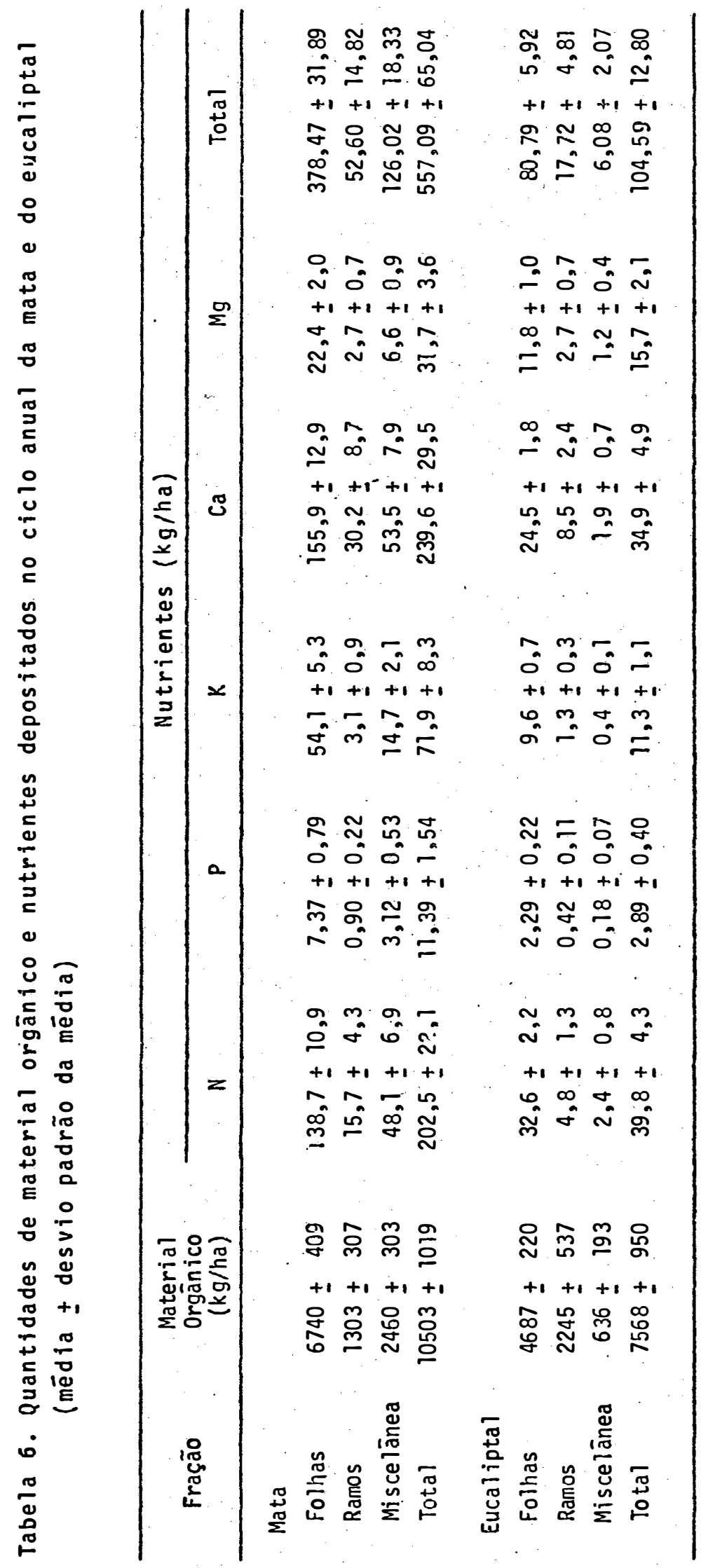


6. DISCUSSÃo

6.1. Aspectos da amostragem da deposição de material orgāni co

Em comparação com uma plantação florestal, a me dição da deposição de material orgānico em uma floresta natú ral heterogênea exige maior intensidade de amostragem para atịn gir um nível de precisão considerado satisfatório. A variabili dade espacial na deposição de material orgānico é maior na flo resta natural, e um dos principais fatores para isto é que as espécies têm comportamentos fenológicos diferentes; exemplos sobre a mata de Lençóis Paulista podem ser vistos. em CARPANEZZI (1975). Além disso, como notou WARMING (1973, p. 224), há 'va riações individuais de fenologia, dentro de cada espécie.

Outros fatores importantes que concorrem para a variabilidade espacial da deposição em uma floresta natural são a atividade da fauna arborīcola e a complexidade da organização espacial da vegetação. Na mata de Lençóis Paulista a ação de ma cacos e serradores (Cerambicideae) ocasionaram, não raro, a queda de ramos com folhas jovens, captados pelas bandejas. De vido à organização espacial da vegetação ocorrem, esporadica mente, grandes deposicões de material orgänico em áreas peque nas e descontinuas, em consequéncia da queda de ārvores ou ra 
mos grandes, os quais podem causar, adicionalmente, quedas em cadeia de materiais de outros estratos, principalmente quando hà ocorrência de lianas.

Atendo-se à amostragem por bandejas, 0 tempo gasto na divisão do material decĩduo em componentes isolados folhas, ramos e miscelānea, na presente investigação - é fator limitante para a adoção de intensidades de amostragem elevadas em florestas naturais heterogēneas. A separação do material co letado mensalmente em cada bandeja do eucaliptal pōde ser sem pre realizada em menos de 10 minutos. Entretanto, para o mate rial da mata houve necessidade de ao menos 40 minutos para a paração criteriosa das frações de cada bandeja.

A grande maioria dos trabalhos publicados sobre de sição de material orgānico não apresenta medidas de disper sao da amostragem, limitando-se às médias anuais e ou periōdi cas. Consequentemente, não esclarecem qual o nīvel de precisão de amostragem que considerariam adequado.

0 nīvel de precisão julgado satisfatōrio para as deposições de material orgānico varia entre os poucos auto res que tratam do assunto. WILL (1959), KLINGE e RODRIGUES (1968a) e GOSZ et alii (1972) consideraram adequados valores de desvio padrão da média inferiores a $10 \%$ da média, enquanto LANG (1969) os considerou abaixo de $5 \%$ da média. MEDWECKA-KORNAS (1971), adotando proposta de NEWBOULD (s.d.), também considera adequados valores de desvio padrão da média inferiores a $5 \%$ da média.

A adoção de um nível de precisão como satisfató rio é ligada à natureza do fenōmeno medido. Quando é possível controlar rigidamente as causas de variação há exigēncia de precisão maior, e inversamente nos casos em que há dificuldade de controle das causas de variação.

Em função da natureza bastante variável da depo 
sição de material orgānico, estatístico consultados opinaram que valores de desvio padrão da média menores que $10 \%$ da média são considerados satísfatörios.

\subsubsection{Aspectos da amostragem da deposição de material orgānico na mata}

Pelo exame da Figura 5 e Tabela 6 fica evidente que somente a fração foliar apresentou, em todas as coletas e no perīodo anual, valores de desvio padrão da média menores que $10 \%$ da média.

Como pode ser inferidoda Tabela 6 , a fração mis celânea apresentou no ciclo anual o valor de $12,3 \%$ da média pa ra o desvio padrão da média, acima do limite aceitável de $10 \%$. A proximidade entre os 2 indices indica que para o tipo de ma ta investigada nesta pesquisa uma precisão adequada para a fra ção miscelānea poderá ser alcançada com o uso de bandejas, des de que sejam efetuadas modificações na amostragem.

Os valores anuais da fração ramos, expostos na Tabela 6, evidenciam a deficiēncia da amostragem, expressa no valor de $23,5 \%$ da média para o desvio padrão da média. A amos tragem com bandejas não se presta também à medição de frações lenhosas de grandes dimensões, como troncos ou ramos grossos. Para a obtenção de dados precisos sobre a deposição total de frações lenhosas poderão ser utilizadas parcelas maiores que as bandejas, delimitadas no piso florestal. Em povoamento de $P \underline{i}$ nus oocarpa de 12 anos, POGGIANI (comunicação pessoal) utiliza, em carāter preliminar, parcelas de $600 \mathrm{~m}^{2}$ para frações lenhosas, a rais maduros, nos quais a amplitude do material lenhoso dec $\underline{i}$ duo é acentuada - desde gravetos até caules grossos - é partī cularmente interessante a prática de GOSZ et alii (1972), que dividiram o material lenhoso decíduo em diferentes frações e 
utilizaram parcelas de áreas distintas para cada uma. Isto per mite obter, com relativa facilidade, nīveis de precisão adequa dos para cada uma das frações lenhosas.

Na Tabela 6 o valor médio da deposição total de material orgānico da mata deve ser considerado como inferior ao valor da deposição total real, devido à ineficácia da amos tragem para cascas e frações lenhosas do porte de ramos gros sos ou caules. Entretanto, ele serve para comparação com dados da literatura, como os apresentados por BRAY e GORHAM (1964), KLINGE e RODRIGUES (1968a, 1968b), BERNHARD-REVERSAT (1976) e dezenas de outros atores, devido à semelhança de amostragem.

\subsubsection{Aspectos da amostragem da deposição de material} orgānico no eucaliptal

A anālise da Figura 6 e da Tabela 6 revela que somente os pesos da fração foliar foram determinados com pre cisão adequada. No perīodo anual os valores dos desvios padrões das médias para as frações ramos e miscelānea foram de 23,9 e $30,3 \%$ da média, respectivamente, indicando a necessidade de $\underline{a}$ mostragem em separado.

E reconhecido que ārvores de $E$. saligna e de $E$. grandis apresentam cascas decîduas, e que a deposição das cas cas ocorre de modo acentuado na base dos caules. A utilização de bandejas tradicionais, dispostas ao acaso ou sistematicamente, é inadequada para a medição. Para isto poderia ser utiliza do um dispositivo semelhante a uma bandeja, com um orifício cen tral, circundando o caule.

Na mata hā poucas espécies de cascas decīduasprincipalmente cabriutinga (Cyclobium vechii) e guaiaruva ( $\underline{e}$ curinega guaiaruva) - e aparentemente a intensidade de queda de cascas de cada árvore destas espécies é bem menor que nas árvores do eucaliptal. Pode-se considerar, portanto, que a de 
posição anual de cascas decĩduas é maior no eucaliptal do que na mata.

0 valor médio da deposição total de material or gânico no eucaliptal, exposto na Tabela 6 , deve ser considera do como potencialmente inferior ao valor da deposição total re a 1, em decorrência da inadequação da amostragem para medir a deposição de caules, ramos grossos e cascas. Como no caso da mata, hā possibilidade de comparação com dados da literatura, pela semelhança de amostragem.

6.2. Variação estacional da deposição de materiat orgānico

No interior do Estado de São Paulo a observação cotidiana das espēcies nativas revela um perīodo de deposição foliar mais intenso na estação seca, entre os meses de julho e outubro, aproximadamente. Este padrão pode ser tomado como re presentativo da vegetação regional.

6.2.1. Variação estacional da deposição de material or gànico na mata

A anālise da Figura 5 indica que as frações ra mos e miscelānea apresentaram a mesma tendēncia quanto à varia ção estacional. O perīodo de maior deposição iniciou ao final da estação seca e prosseguiu atē meados do verão.

A Figura 5 mostra, no ano de 1977, a ocorrência de um perīodo de deposição foliar mais intensa entre os dias 15.7 e 11.11. Estas datas compreendem as partes central e fí nal da estação mais seca e o inīcio da estação chuvosa. Entré tanto, como mencionado no item 6.4, há indīcios de que a depo sição no perīodo de 14.7 a 19.8 envolveu quantidade significa tiva de folhas não senescentes. Deste modo, a queda de folhas fisiologicamente decíduas deste perīodo, no ano de 1977, deve 
ser considerada menor que a apresentada na Figura 5 .

Em suas linhas gerais a variação estacional da deposição foliar na mata concorda com as informações de RIZZO et alii (1971), WARMING (1973, p. 220-232) e RIZZINI (1979, p. 83), referentes a ecossistemas naturais brasileiros situados em regiões de climas similares. Ela assemelha-se, também, ao pa drão observado no mesmo. ano por POGGIANI (1978) em povoame tos de Pinus oocarpa, no municīpio vizinho de Agudos.

As informações das Figuras 1,5 e 6 permitem su por que, na mata e no eucaliptal, a época de maior deposição foliar foi equivalente nos 2 anos, embora o ano de 1977 não te nha apresentado estação de menor precipitação. Isto sugere que, independente das chuvas, hā outros fatores ambientais e ou fí siológicos associados à caducifolia. Pode-se citar, como poss $\overline{\bar{i}}$ veis fatores ambientais, as variações estacionais de fotoperīo do e temperatura.

Foram observadas variações quanto $\bar{a}$ intensida de de desfoliação aparente das espécies da mata, no perīodo se co. Peroba rosa (Aspidosperma polyneuron) e guatambu branco (A. ramiflorum), por exemplo, apresentam sinais leves de deci duidade foliar, ao passo que araribá (Centrolobium sp), cedro (Cedreza sp) e paineira (Chorisia speciosa) perdem todas as fo 1has. A diferença entre os comportamentos reflete caracteristí cas adaptativas das espécies, não esclarecidas por ora.

6.2.2. Variação estacional da deposição de material or gānico no eucaliptal

Embora de precisão insatisfatōria, as informa ções das figuras 1 e 6 indicam que no eucaliptal a deposição das frações ramos e miscelànea foi mais intensa em ocasiões do período chuvoso. Em floresta de E. regnans, ASHTON (1975) tam 
bēm verificou que a ocorrēncia de tempestades pode provocar maior queda de ramos.

A Figura 5 e 6 indicam que no eucaliptal a va riação estacional da deposição foliar foi menos acentuada do que na mata. Com efeito, a razão entre as médias das coletas de máxima e mīnima deposição diāria foi de 6,5:1 na mata e 3,2:1 no eucaliptal. Comparativamente, portanto, a queda de fo lhas no eucaliptal teve menor associação com as condições cli máticas regionais.

A Figura 6 mostra que no eucaliptal a deposição foliar acentuou-se no final da primavera e no verão, períodos de temperatura e pluviosidade elevadas. Dados de POGGIANI (co municação pessoal) sobre plantação de $E$. saligna de 6 anos, em solo de antiga mata, em Piracicaba, SP, mostram padrão similar, com deposição foliar mais intensa no verão. Os eucaliptais, por tanto, diferem da vegetação natural da região, quanto à varia ção estacional da deposição de folhas, e aproximam-se do padrão inferido de SPECHT e BROUWER (1975) para espëcies do leste da Austrālia, região de onde $E$. saligna e $E$. grandis são originā rias.

0 item 6.4. propõe uma explicação para o pico isolado da coleta de 19.8.77, mostrado na Figura 6 .

De acordo com as observações de RIZZO et ali $i$ (1970) e WARMING (1973, p. 220-232), a queda de folhas das ār vores do cerrado é mais intensa no periodo de menor pluviosidá de do ano. Todavia, informações presentes em FERRI (1964), GOODLAND (1979a, p. 13-20) e RIZZINI (1979, p. 114, 145 e 167) deixam claro que o fato não pode ser atribuîdo de modo exclusivo ou principal às condições de disponibilidade de água do solo. Por tanto, outros fatores ambientais e ou fisiológicos estão envol vidos. Devido às diferenças nas características de variação es tacional da queda de folhas em eucaliptais e em cerrados, pode 
ser considerado que os fatores que controlam a deposição fol 1 ar em cerrados e em eucaliptais tambēm diferem.

A manutenção das folhas do eucaliptal no perīo do mais seco do ano poderia, aparentemente, ser tomada como pro va de que não hā restrição sēria à transpiração nesta ēpoca. Isto seria possîvel devido a desenvolvimento de sistema ra dicular profundo, usualmente atribuído aos eucaliptos planta dos no Brasil, embora informações numéricas, como as de FERRI (1964), sejam raras. As raīzes profundas poderiam, potencia mente, garantir suprimento adequado de āgua.

A hipōtese não estā provada de modo direto, atu almente. Além disso, ela explicaria a manutenção de folhas no perīodo mais seco, mas não a queda no período quente e chuvoso.

Segundo SPECHT e BROUWER (1975), investigações demonstraram que a foliação e a desfoliação tendem a ocorrer simultaneamente em comunidades perenifōlias da Austrália. Base ados nesta tendéncia, os autores admitem que o padrão de depo sição foliar pode dar uma idéia razoável da variação estacio nal do crescimento de gemas. Aceitando esta suposição para eu caliptais de Lençōis Paulista e Piracicaba, a variação esta cional da deposição foliar pode, em hipótese, ser associada ao estabelecimento de desnīvel de concentração de auxina entre ra mo e limbo, apontado por STREET e ÖPIK (1974, p. 295-303) como um fator crītico na abcisão. 0 crescimento intenso de gemas se ria decorrente das condições ambientais do fim da primavera e do verão. Como as gemas e as folhas jovens são centros impor tantes de sintese de auxinas, o movimento basipetalar das aux $\underline{i}$ nas resultaria em desnível de concentração entre ramo e 1 imbo, devido ao aumento do nível de auxinas do ramo.

A intensificação de deposição foliar nos euca liptais de Lençōis Paulista e Piracicaba ocorreu em período quente e chuvoso. Baseando-se em SPECHT e BROUWER (1975), a ele 
vação de temperatura é o mais provāvel fator ambiental que po deria desencandear o crescimento intenso de gemas nos eucalip tais de Lençōis Paulista e Piracìcaba, no período de deposị ção foliar mais intensa. Resumindo dados australianos referen tes a espécies de Eucalyptus a sul do Trópico de Capricórnio, os autores afirmam que o crescimento de gemas é inibido por temperaturas mensais abaixo de $16-18^{\circ} \mathrm{C}$, e que o fotoperiodo e a umidade do solo não têm papel decisivo no fenómeno. Corrobo rando esta hipótese, cozzo (1971) verificou, em Buenos Aires, Argentina, em plantações de E. camaldulensis, maior deposição foliar no verão, sem precipitações, apōs as chuvas da primavera.

\subsection{Deposição anual de materià orgānico}

Segundo dados coletados na sede da Fazenda Rio Claro, os anos de 1976 e 1977 apresentaram precipitações ac ma da média, atingindo 1789 a $1400 \mathrm{~mm}$, respectivamente. Estes fatos justificam a recomendação de MEDWECKA-KORNAS (1971) de que a deposição de material orgānico de um ecossistema flores tal qualquer deve ser medida por um perīodo mīnimo de 3 anos.

\subsubsection{Deposição anual de material orgānico na mata}

A Tabela 6 indica que as folhas corresponderam a $64,0 \%$ do total de material orgānico depositado. Esta percen tagem enquadra-se na faixa de 60-80\% em que estão comumente s $\underline{i}$ tuados os valores determinados em florestas tropicais e subtro picais, quando são empregadas parcelas de coleta semelhantes. Todavia, a fração miscelānea correspondeu a $23,4 \%$, superior aos valores de $1-15 \%$ comumente encontrados.

A deposição total anual da mata é elevada para sua latitude, equiparando-se com as florestas tropicais úmidas quando interpolada no gráfico apresentado por BRAY e GORHAM (1964, p. 128). Aparentemente, este fato é consequéncia das ca 
racterísticas edáficas locais, as quais conferem, potencialmen te, alta produtividade ao ecossistema.

A Tabela 7 mostra que as deposições de nutrien tes e do total de material orgānico da mata são próximas dos valores determinados por NYE (1961), em floresta secundáriade cerca de 40 anos, em Ghana. As participações da deposição foli ar em relação ao total de material orgānico deposto, determina do por uso de bandejas, também são semelhantes $(64,0 \%$ na mata de Lençóis Paulista e dois terços em Ghana).

Na floresta de Ghana, NYE (1961) avaliou, por meio indireto, a deposição anual de material lenhoso de gran des dimensões ("timber fall") em $11200 \mathrm{~kg} / \mathrm{ha}$. 0 método utili zado baseia-se na suposição de que em florestas plenamente de senvolvidas a deposição anual de material lenhoso grossoé equi valente à produção anual de madeira.

0 método empregado por NYE (1961) permite a es timativa da deposição de material lenhoso de grandes dimensões na mata de Lençōis Paulista. Considerando que o valor da rela ção entre as taxas de "increment" a / de floresta subtropical e tropical apresentadas por RODIN e BAZILEVIC (1967) é de 75\%, e multiplicando $11200 \mathrm{~kg} / \mathrm{ha}$ por 75\%, o "timber fall" anual da mata de Lençóis Paulista alcançaria $8400 \mathrm{~kg} / \mathrm{ha}$. E desejável, sem dūvida, que este valor seja testado, através de mensura ções diretas.

a/ "Increment... (is)... the annually increasing mass of leaves and herbaceous organs plus the increment of wood and roots". RODIN e BAZILEVIC (1967, p. 27) 


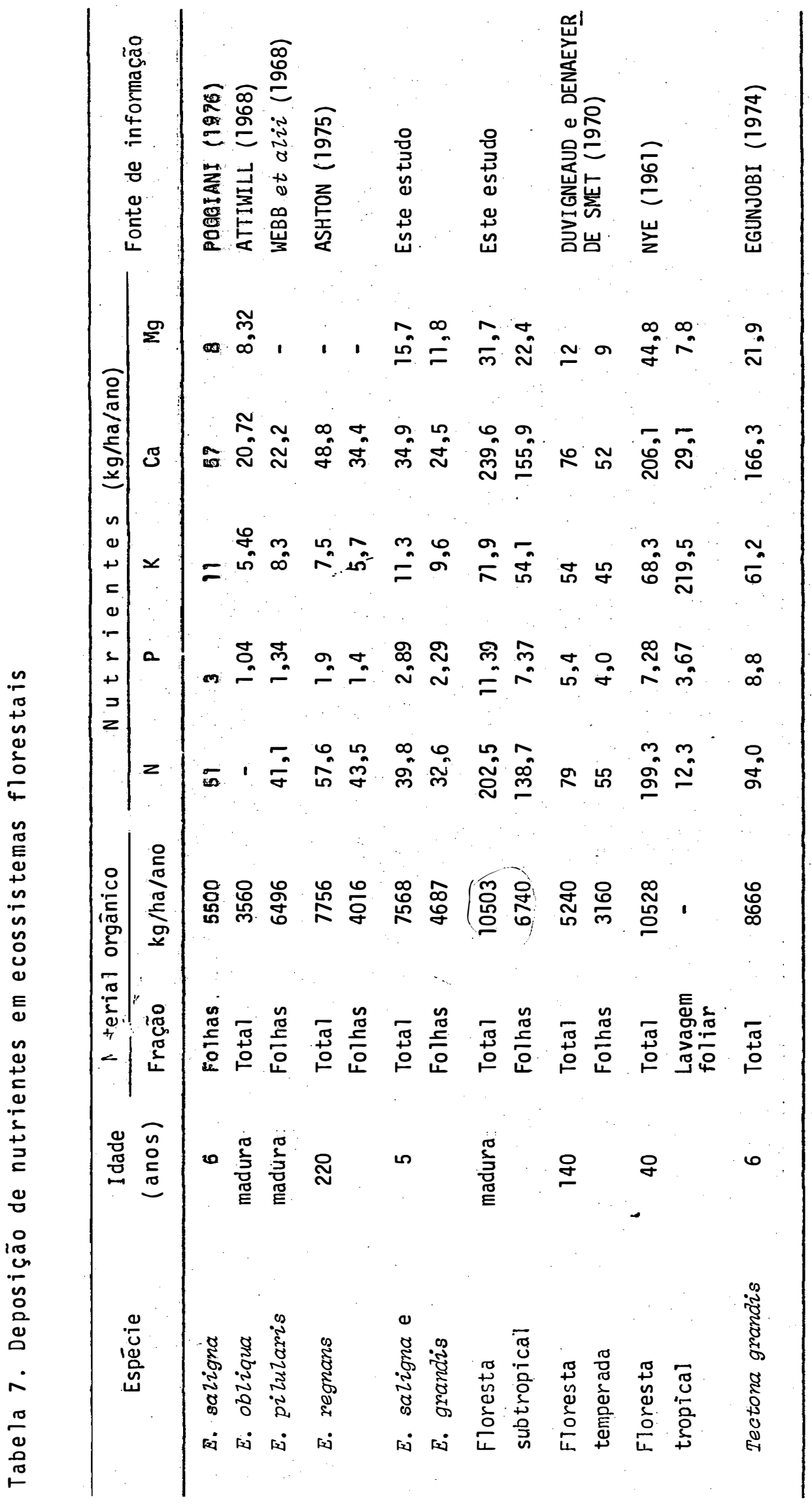


Não é possível aplicar o método proposto por NYE (1961) para o eucaliptal, pois sua biomassa estā em expan são. Todavia, baseando-se nas porcentagens de falhas e de árvo res mortas, a deposição média anual de material lenhoso de gran des dimensões pode ser estimada, grosseiramente, como inferior a $1000 \mathrm{~kg} / \mathrm{ha}$, no perīodo dos primeiros 5 anos. E desejāvel que também esta estimativa seja testada na prātica, em ecossiste mas similares.

A comparação das estimativas apresentadas evi dencia a necessidade da medição de "timber fall" em ecossiste mas florestais, sempre que houver desejo de determinar a magn $\underline{i}$ tude real da deposição de material orgānico.

A deposição de material lenhoso de grandes di mensões contribui de modo relevante para a heterogeneidade da organização espacial e da composição quĩmica do piso florestal. Quanto maior a variação destas características, maior o nūmero de formas de vida que podem viver ali. O material lenhoso do piso da mata, em maior quantidade e mais heterogēneo que o do eucaliptal propicia, comparativamente, maior diversidade bioló gica.

6.3.2. Deposição anual de material orgānico no eucalip tal

Como indicam os dados da Tabela 6 , no eucalip tal as folhas corresponderam a $61,9 \%$ do material orgānico depo sitado nas bandejas, valor considerado normal quando comparado a literatura mundial. A fração ramos, todavia, situou-se acima do normal, equivalendo a $29,6 \%$. A deposição elevada de ramos concorda com resultados de ASHTON (1975), que determinou valo res de $21-27 \%$ em florestas de $E$. regnans. 0 autor atribuiu a elevada participação de ramos à rápida lignificação dos lança mentos, considerada por JACOBS (1955) como uma caracteristica de eucaliptos de rápido crescimento. 
Embora o eucaliptal tenha apenas 5 anos de ida de e esteja situado em solo originalmente pouco fértil, seu to tal de deposição de material orgānico, mostrado na Tabela 6 , é considerado normal para a latitude em que se encontra, de acordo com gráfico proposto por BRAY e GORHAM (1964, p. 128).

Na literatura consultada não hā dados confiāveis sobre a deposição anual de material orgānico em cerrados; não é possível, portanto, a comparação segura do eucaliptal com a vegetação primitiva do local, um cerrado aberto. Todavia, a média de deposição foliar anual do eucaliptal, igual a 4687 $\mathrm{kg} / \mathrm{ha}$, equivale a 5,3 vezes o valor apontado por HOPKINS (1966) para savana antrópica da Nigéria, a 1,6 vezes o valor indicado por MALAISSE et alii (1975) para savana do Zaire e a 1,1, vezes o valor determinado por RIZZO et alii (1971) em cerrado próxi mo a Goiània al.

Dois aspectos devem ser objetos de atenção na comparação entre as taxas de deposição de material orgânico de uma plantação florestal e de um cerrado. 0 primeiro é que a ta $x a$ de deposição de uma plantação jovem, como o eucaliptal de Lençóis Paulista, aparentemente não é constante, aumentando de ano a ano. E conveniente, portanto, a obtenção de uma média anual que possa exprimir a deposição proporcionada por cada ci clo de corte; esta média deve incorporar os resíduos de explo ração. Outro aspecto é a necessidade de quantificar a deposi ção de material orgānico proporcionada pelo estrato inferior dos cerrados (principalmente pelas gramíneas), ao lado da depo sição dos estratos arbustivo e arbóreo. Como indicam os dados

a/ Os autores apresentaram gráficos com dados de 6,5 meses de coleta; para o cálculo do período restante foi considerada a deposição mensal de $200 \mathrm{~kg} / \mathrm{ha}$, adotada a partir de informa ções do artigo. A amostragem utilizou somente uma parcela de $1 \mathrm{~m}^{2}$ e não há indicação explícita de secagem do material co letado. 
de MALAISSE et alii (1975), referentes a uma savana do Zaire, a contribuição do estrato inferior pode ser muito importante.

ANDRADE (1940) informou ter medido por 8 anos a deposição de material orgānico em eucaliptais paulistas e de terminado o valor de $14000 \mathrm{~kg} / \mathrm{ha}$. 0 autor não forneceu infor mações precisas sobre os povoamentos medidos e a metodologia utilizada; da leitura do artigo conclui-se, todavia, que não foram incluídos ramos grossos ou caules. Não há indicação ex plicita de que o material coletado tenha passado por secagem.

o total anual da deposição no eucaliptal de Len çóis Paulista é claramente inferior ao encontrado por ANDRADE (1940). Ele é, entretanto, próximo ao valor total do povoamen to de Eucalyptus saligna de 6 anos de idade mencionado por POGGIANI (1976), segundo comunicação pessoal.

Como mostra a Tabela 8 , a relação entre a média da deposição foliar anual do eucaliptal (4687 kg/ha) e a área basal considerada representativa do perīodo de medições (20,3 $\mathrm{m}^{2} / \mathrm{ha}$ ) é de $231 \mathrm{~kg} / \mathrm{m}^{2}$. Este valor é superior ao de $70-75 \mathrm{~kg} / \mathrm{m}^{2}$, determinado por BONNEVIE-SVENDSEN e GJENS (1957), citado por BRAY e GORHAM (1964), em populações de folhosas e coníferas, na Noruega. Adicionalmente, o eucaliptal apresenta maior velo cidade de crescimento em área basal, o que contribui potencial mente para aumentar a diferença entre as taxas acumuladas de de posição do eucaliptal de Lençóis Paulista e dos ecossistemas nōrdicos.

A Tabela 8 evidencia a proximidade entre os va lores da relação deposição foliar: área basal para as plantạ ções de eucaliptos consideradas. Este fato permite prever a possibilidade futura de fixar correlações entre valores de ārea basal e de deposição de material orgānico em plantações flores tais brasileira, desde que novas investigações sejam feitas. 


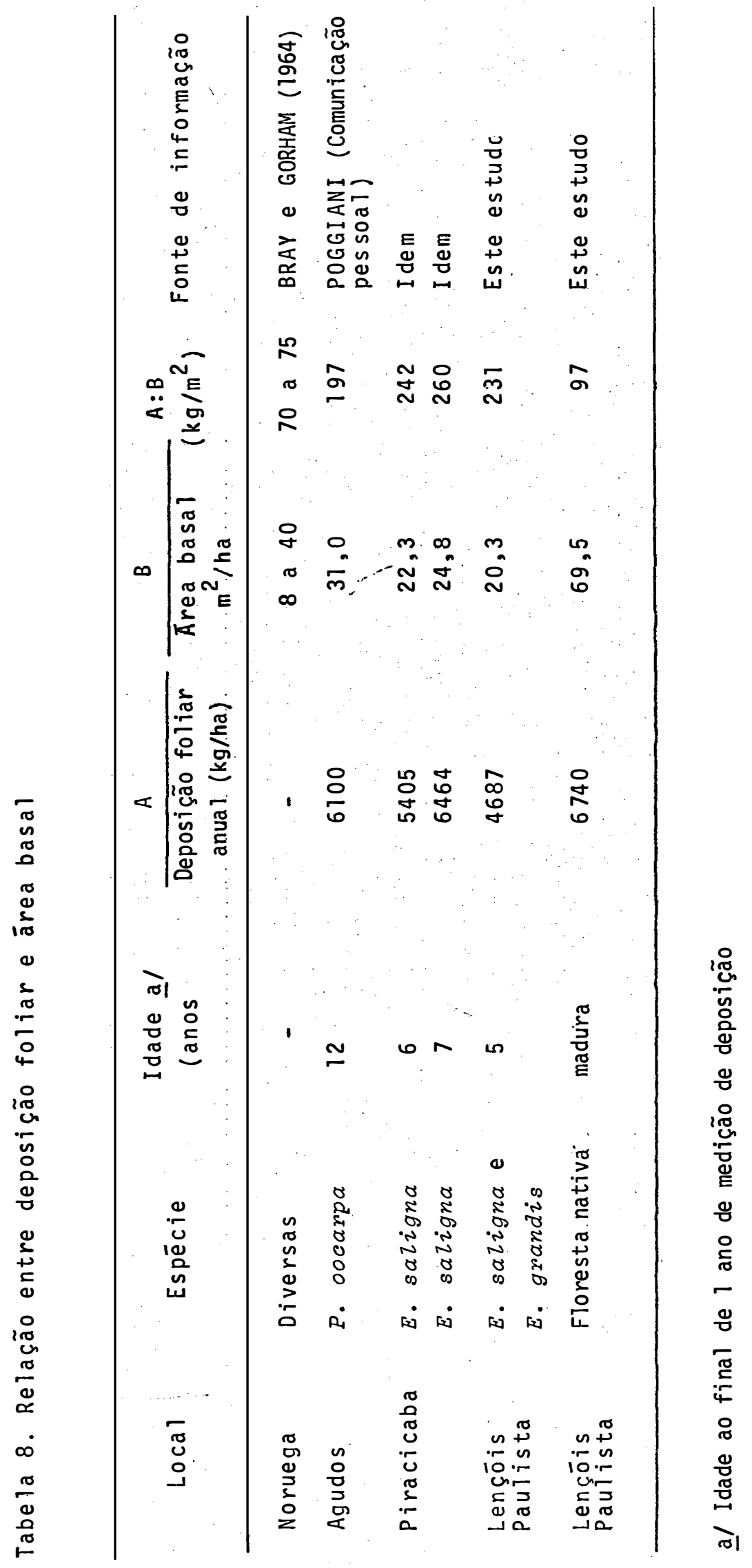


Outrossim, considerando que a ārea basal do eucaliptal de Len çóis Paulista ainda está aumentando, pode-se prever que sua de posição foliar aos 6 anos será prōxima à do eucaliptal de mes ma idade, situado em Piracicaba.

Na literatura consultada não há informações que permitam a comparação da relação deposição foliar: ārea basal da mata, apresentada na Tabela 8 , com dados de ecossistemas si milares, subtropicais.

\subsection{Variação estacionaj da concentração de nutrientes}

Como mencionado no $\overline{\text { Ttem }}$ 6.2., no interior do Es tado de São Paulo há um ápice de deposição foliar de julho a outubro, aproximadamente. Deste modo, o exame superficial da Figura 5 faz supor que no perīodo de 15.7 a 19.8 tenha ocorri do grande queda de folhas fisiologicamente decíduas na mata.

Entretanto, a elevada concentração de $K$ na fra ção foliar da coleta deste período, mostrada na Figura 7, im plica em expressiva participação de folhas mais jovens. Segun do observações locais, no dia 23.7 ocorreram ventos fortes e precipitação; supõe-se que estes fatos tenham ocasionado a que da de folhas mais jovens. Outras características da coleta de 19.8, como o pico isolado de deposição de folhas no eucaliptal, com alto teor de K (Figuras 6 e 8 ) e a elevação das quedas de ramos na mata e no eucaliptal (Figuras 5 e 6 ), reforçam a hipotese. Não houve geadas no perīodo. Exemplos similares foram ob servados por WEBB et alii (1969), GOSZ et alii (1972) e GESSEL e TURNER (1976).

A Figura 5 indica que na mata as duas coletas apōs 19.8 tịveram, presumidamente, participação maciça de fó lhas fisiologicamente decíduas. A Figura 7 , pois, permite con jeturar que as concentrações de $N$ não diferem de modo marcante entre as folhas jovens (19.8) e as fisiologicamente decíduas 
(13.9 e 7.10). Esta suposição não é afetada por possīvel inter ferēncia de lavagem foliar ou de contribuição atmosférica: o $N$ é um elemento pouco susceptível de arrastege a Figura 1 indica que as precipitações do perî́odo de 20.8 a 7.10 foram baixas.

A constância nas concentrações de $N$ das folhas da mata concorda com as observações de NYE (1961). Para este autor, nas folhas de espécies tropicais as migrações de $\mathrm{N}$ an tes da queda seriam consideravelmente menos importante que nas espécies da zona temperada. Como sugeriu DOMMERGUES (1963), es te comportamento poderia explicar a maior concentração de $N$ do material de deposição de florestas tropicais.

As informações da Figura 8 permitem supor que tambēm no eucaliptal hä constāncia da concentração de $\mathrm{N}$ em fo lhas fisiologicamente decî́duas e em folhas mais jovens. Na $1 \underline{i}$ teratura consultada não há informações sobre este aspecto; en tretanto dados de HAAG et alii (1976), sobre folhas verdes de eucaliptos, permitem supor a movimentação do nutriente. A com provação deste comportamento e a elucidação de outras questões que surgem do exame das Figuras 7 e 8 - como o contraste entre os picos de concentração de $K$ e a relativa invariabilidade das concentrações de $P$, Ca e Mg na mata - exigem a realização de pesquisas orientadas estritamente para tais finalidades. A in clusão de medições sobre lavagem foliar e a caracterização pe riódica das concentrações de nutrientes em folhas verdes serão essenciais nestas investigações.

\subsection{Concentrações de nutrientes no material deposto no pe riodo anual}

Como mostra a Tabela 5, a fração foliar da mata apresentou maior concentração total de nutrientes que a fração ramos, e os teores de Ca de ambas foram equivalentes, fatos constatados também em outras investigações. A concentração tó 
tal da fração miscelānea foi prōxima à da fração foliar, con cordando com resultados obtidos por KLINGE e RODRIGUES (1968b), GOSZ et alii (1972), EGUNJOBI (1974) e BERNHARD-REVERSAT (1976).

A Tabela 5 revela que no eucaliptal as frações ramos e miscelànea foram bem diferenciadas das folhas quanto à concentração total. A respeito da concentração de $\mathrm{Ca}$, a rela ção ramos: folhas é inferior à da mata $(0,7: 1$ no eucaliptal e $1: 1$ na mata), concordando com dados de ASHTON (1975) sobre gra vetos de $E$. regnans.

Comparando as concentrações da fração foliar da mata com resultados referentes a 20 ecossistemas de folhosas de diversas partes do mundo a /, verifica-se que o teor de $\mathrm{Mg}$ da mata encontra-se próximo à média dos valores dos ecossiste mas considerados, enquanto os demais elementos - particularmen te $\mathrm{N}$ e Ca - encontram-se acima da média. As concentrações da fração foliar do eucaliptal encontram-se claramente abaixo da média dos valores dos ecossistemas considerados, com exceção da concentração do $\mathrm{Mg}$, mais próxima da média.

Como indicado em OVINGTON (1968) e SPURR e BURTON (1973, p. 173), as árvores duma espécie podem controlar, dentro de amplas variações dos solos em que vivem, as concen

a/ Os dados originais foram retirados de MAHEUT e DOMMERGUES (1960), KLINGE e RODRIGUES (1968b), WEBB et alii (1969), DUVIGNEAUD e DENAEYER-DE SMET (1970), GOSZ et alii (1972), KRAMER e KOSLOWSKI (1972, p. 306), EGUNJOBI (1974), JOHNSON e RISSER (1974), ASHTON (1975), BERNHARD-REVERSAT 91976) e POGGIANI (1976). As médias e os desvios padrões das médias são: $N=1,20 \pm 0,11 ; P=0,079 \pm 0,009 ; K=0,59 \pm 0,08$; $\mathrm{Ca}=1,34 \pm 0,15$ e $\mathrm{Mg}=0,31 \pm 0,03$. 
trações de nutrientes de seus órgãos. Por outro lado, em ocor rềncia natural as espécies que apresentam maior teor de nutrí entes nas folhas tendem a ocupar solos mais férteis, teorica mente por encontrarem, ali, condições que lhes possibilitam maior probabilidade de vida. Assim, as elevadas concentrações de nutrientes das folhas da mata devem ser entendidas como de correntes das propriedades do solo e de caracterīsticas ineren tes às espēcies.

Os valores anuais das concentrações de nutrien tes das folhas decíduas do eucaliptal podem ser considerados normais quando comparados aos valores de ATTIWILL (1968), WEBB et alii (1969), ASHTON (1975) e POGGIANI (1976), referentes a ecossistemas naturais de $E$. obliqua, E. pilularis e E. regnans e plantação de $E$. saligna, respectivamente.

A comparação direta dos teores de nutrientes da mata e do eucaliptal, mostrados na Tabela 5 , evidencia os valo res menores do eucaliptal. A produtividade anual de madeira co mercial do eucaliptal - $50 \mathrm{st} / \mathrm{ha}$, aproximadamente - é verifica da somente em eucaliptais sem deficiencias minerais aparentes e, portanto as concentrações de nutrientes devem ser encaradas como normais. E importante mencionar que a plantação de $E$. sa Zigna investigada por POGGIANI (1976) em Piracicaba ocupa solo de antiga mata e apresenta produtividade anual elevada, próxi ma a $60 \mathrm{st} / \mathrm{ha}$. A constāncia das baixas concentrações foliares destes 2 eucaliptais (em relação às mēdias dos 20 ecossistemas de folhosas considerados) reforça a hipótese de que o fato pos sa ser uma característica de espécies de Eucazyptus.

\subsection{Deposição anual de nutrientes}

Excetuando-se o Mg, os totais de nutrientes depo sitados na mata, mostrados na Tabela 6 , aproximam-se dos maiores valores determinados em florestas tropicais e subtropicais da 
América e da África, segundo dados comparativos reunidos por KLINGE e RODRIGUES (1968a, 1968b) e EWEL (1976). A deposição anual média de $M g(31,2 \mathrm{~kg} / \mathrm{ha})$ situa-se cerca de $10 \mathrm{~kg}$ abaixo da média dos maiores valores compilados por estes autores.

A deposição de nutrientes na mata pode ser con siderada elevada em termos mundiais, já que as florestas trop $\underline{i}$ cais e subtropicais apresentam taxas de deposição superiores às das florestas temperadas.

As características edáficas da mata foram apon tadas como possíveis responsáveis pelos valores elevados das concentrações de nutrientes e da deposição de material orgāni co. Estes dois aspectos, combinados, conduziram à taxa anual de deposição de nutrientes também elevada. Entretanto, a vege tação investigada está restrita aos solos mais ricos quimica mente e com maior disponibilidade potencial de água. Presumese,pois, que o estabelecimento de ecossistema de estrutura po pulacional semelhante, com a manutenção das taxas de deposições observadas, somente poderá ser conseguido em condições edáfí cas equivalentes.

A Tabela 7 indica que as taxas de deposição da mata assemelham-se notavelmente às da floresta investigada por NYE (1961). Nesta floresta, de precipitação anual prōxima a $1625 \mathrm{~mm}$, a Tabela 7 mostra participação intensa da lavagem fol $\underline{\mathbf{i}}$ ar na restituição de $K$ e $P$. Entretanto, os percentuais de lava gem foliar não podem ser transferidos entre ecossistemas, de vido às particularidades de cada um, as quais determinam taxas de remoção de nutrientes distintas. Torna-se evidente, pois, a conveniência da determinação da lavagem foliar em cada ecos sistema, para melhor quantificação da etapa da restituição de nutrientes, condição essencial a sua interpretação correta.

Os dados sobre deposição de nutrientes em for mações de Eucalyptus são escassos e envolvem variabilidade quan to a espécies, idades e locais. A Tabela 7 indica que os valo 
res do povoamento de Lençóis Paulista podem ser considerados normais, quando comparados aos demais ecossistemas de Eucalyp tus. A Tabela 7 tambēm evidencia que os ecossistemas de Eucalyp tus apresentam taxas de deposição de nutrientes inferiores às dos outros ecossistemas, e que esta situação decorre principal mente de concentrações de nutrientes mais baixas no material caîdo.

Informações constantes em OVINGTON (1968), DU VIGNEAUD e DENAEYER-DE SMET (1970) e PRITCHETT (1979, p. 203205 ) indicam que a restituição anual de nutrientes pela depos $\underline{i}$ ção de material orgānico constitui fração importante, embora va riável, da absorção total anual de nutrientes do ecossistema. Atendo-se a este conceito, o fato de o eucaliptal apresentar produtividade elevada e taxas de deposição de nutrientes baixas configurā-lo-ia como constituỉdo de espécies pouco exigentes em nutrientes, quando comparado aos ecossistemas da Tabela 7 (exce to outros eucaliptais) e similares.

Entretanto, segundo PRITCHETT (1979, p. 200), em um ecossistema florestal a absorção total anual de nutrientes e o acúmulo líquido anual de nutrientes na biomassa alcançam valores máximos na fase inicial, de rápido crescimento. Dados de METRO e DE BEAUCORPS (1958) e LUBRANO (1968) permitem uma idéia da magnitude da retenção anual de nutrientes na madeira exportável, em eucaliptais do Norte da África e da Europa. Em florestas maduras a retenção líquida anual corrente de nutrien tes na biomassa é nula, pois a biomassa é constante; embora a taxa de absorção anual seja inferior à da fase de rápido cresci mento, a relação deposição: absorção é igual a 1 .

Evidencia-se, portanto, que os valores de resti tuição não são indicadores seguros de exigēncia nutricional de espēcies, principalmente quando não há informações sobre produ ção anual de biomassa e quando os dados de restituição são par ciais e ou são empregados para comparar ecossistemas em estā 
gios sucessōrios distintos. Somente o conhecimento da relação entre as taxas anuais de construção de biomassa e de absorção de nutrientes permite quantificar e comparar exigēncias nutri cionais. DUVIGNEAUD e DENAEYER-DE SMET (1970) apresentam exeplo da obtenção destas taxas, em floresta da Bélgica.

\subsection{Efeitos do eucaliptal sobre o solo}

A determinação da influência do eucaliptal so bre o solo somente poderia ser realizada caso fosse disponīvel um conjunto de informações referentes aos dois ecossistemas, o atual e o antigo, um cerrado aberto. 0s valores sobre as depo sições de material orgānico e de nutrientes do eucaliptal cons tituem apenas fração das informações necessārias e permitem somente abordagem, de modo genérico, de possīveis consequēn cias.

6.7.1. Efeito da deposição anual de material orgânico

A média da deposição anual de material orgânico no eucaliptal foi de $7600 \mathrm{~kg} / \mathrm{ha}$, aproximadamente. 0 valor é potencialmente inferior ao real, por excluir cascas, caules e ramos grossos, devido ao sistema de amostragem empregado. Não hā, por ora, informações que permitam estimar a deposição du rante um período amplo, como os 6-7 anos de cada corte.

Referindo-se a cerrados do Triāngulo Mineiro, GOODLAND (1979b, p. 141) afirma que o nível de matéria orgāni ca dos solos é baixo porque a vegetação esparsa não produz man ta considerāvel. Entretanto, pela literatura consultada, a úni ca comparação numérica possível entre taxas de deposição do eu caliptal e de cerrados é através dos dados de RIZZO et ali $\bar{i}$ (1971), cujas ressalvas são mencionadas no item 6.3.2. A média da deposição foliar anual do eucaliptal foi ligeiramente supe rior à do cerrado.

Considerando por hipótese uma igualdade de depo 
sição de material orgānico entre um cerrado e um eucaliptal que o substitua, pode-se assumir, mantidas constantes outras condições, que no eucaliptal o material decíduo será incorpora do ao solo em maior proporção. Isto provém da ocorrēncia fré quente de fogo nos cerrados na estação seca - em que a depos $\underline{i}$ ção e o acūmulo de material orgānico são elevados - ocasionan do a destruição da camada de detritos orgānicos superficiais. A queima acarreta, tambēm, perdas de $N$ e $S$, por volatilização. obviamente, a ocorrência de incēndios em eucaliptais é rara, devido às medidas de proteção adotadas.

Segundo OVINGTON (1968) o material orgânico de positado por certas espécies florestais tem decomposição lenta e acumula-se na superfície do solo, podendo imobilizar aí con siderável quantidade de nutrientes, a qual deixa de ser dis ponỉvel às plantas. Não é suficiente, portanto, que uma plan tação florestal deposite quantidade satisfatória de material orgānico. Adicionalmente, sua taxa de decomposição deve ser adequada para tornar efetiva a ciclagem de nutrientes no inte rior do ecossistema.

$\mathrm{Na}$ literatura consultada não hā informações sobre velocidades de decomposição do material orgânico caỉdo em matas, cerrados ou plantações flore stais brasileiras. Godaseavação cotidiana de matas e eucaliptais e dados prelimi nares comparativos do autor permitem supor que a relação depo sição: decomposição em eucaliptais não leva ao acúmulo excessi vo de material orgānico e nutrientes no piso florestal. A supo sição é reforçada ao comparar-se talhões de eucaliptos com ta Ihões de Pinus spp, em que a decomposição do material orgānico caîdo é reconhecidamente lenta.

Os efeitos alelopáticos constituem outro aspec to importante da qualidade do material orgánico depositado; en tretanto, os conhecimentos sobre as plantações florestais são 
praticamente nulos. E previsto que a médio prazo este assunto seja considerado de prioridade. elevada, pois a condução da sub mata é importante opção dentro das atividades de manejo da ví da silvestre em plantações florestais.

\subsubsection{Efeito da deposição anual de nutrientes}

E reconhecido que hā, a longo prazo, um acūmu 10 de nutrientes na camada superior de solos sob florestas. Ba sicamente, o aumento é explicado pelo fato de que as raîzes das ārvores absorvem continuamente nutrientes das camadas profun das do solo e os depositam no piso florestal, através da lava gem das copas e da deposição de material orgânico. A seguir, os nutrientes depositados são incorporados ao solo.

Segundo PRITCHETT (1979, p. 196) a fertilização artificial aumenta a produtividade por seu efeito em si e pelo desencadeamento de processos que aumentam as taxas de circula ção de nutrientes dentro do ecossistema. Isto ocorre também no processo de fertilização da camada superficial pela vegetação arbórea. Como exemplo, BAKER (1950, p. 180) relata que as gran des quantidades de Ca depositados por Fagus sp criam melhores condições à fixação de $N$ por microrganismos.

0 conceito de que as florestas concorrem para a melhoria dos solos provém principalmente da formação da camada superficial com concentrações elevadas de nutrientes, a qual é benéfica à instalação de culturas agrícolas. A formação da camada superior de acūmulo é função direta da deposição de nú trientes. Valores parciais de deposição de nutrientes em plan tações florestais brasileiras são apresentados na Tabela 7 . Na literatura consultada não há dados comparativos sobre cerrados.

Em geral, as plantações brasileiras de eucalip tos são aproveitadas em rotações curtas, dimensionadas em fun 
ção da manutenção de taxas elevadas de crescimento. como men cionado no item 6.6., esta prātica tende a tornar māxima a ex portação anual de nutrientes.

Configura-se, portanto, ao lado da contribuição de nutrientes à camada superior do solo, uma exportação poten cialmente intensa de nutrientes pelos cortes, principalmente quando a madeira é retirada com casca. Este quadro concorda com METRO e DE BEAUCORPS (1958), que afirmam que uma plantação florestal pode, simultaneamente, contribuir para a formação de uma camada superficial rica em nutrientes e reter anualmente quantidades considerāveis de nutrientes na madeira exportável.

Embora o acūmulo superficial seja ūtil para com pensar a evasão de nutrientes do ecossistema, OVINGTON (1968) adverte que retiradas intensas de madeira podem ocasionar um declínio de produtividade, pela incapacidade de o solo gerar quantidades equivalentes às dos nutrientes exportados. A qua $\underline{n}$ tificação periōdica de nutrientes disponīveis no solo e na se rapilheira permite uma avaliação da influência das plantações sobre as reservas químicas e previne a ocorrēncia de situações nutricionais críticas.

No estabelecimento de plantações de alta produtị vidade em cerrados hā aplicação de calcārio e fertilizantes, por ocasião do plantio. Mesmo assim, para eucaliptais em rota ções curtas a fertilização pōs-exploração parece ser uma neces sidade para a manutenção de capacidade produtiva local, pois os solos de cerrados são pobres em nutrientes prontamente dis ponīveis e em minerais intemperizáveis. Com estas adições de nutrientes não hā muito a temer quanto ao depauperamento das condições químicas do solo. Obviamente, devem ser realizados a companhamentos periōdicos - abrangendo também condições poten cialmente desfavorāveis, como é o caso de plantações estabele cidas sem adição de nutrientes - para que sejam obtidos dados numēricos elucidativos. 


\subsection{Sugestões para investigações}

Como fica evidenciado ao longo deste trabalho, há carência de conhecimentos sobre aspectos ecológicos de plan tações florestais e de formações naturais. Esta situação impe de a compreensão da dināmica funcional dos ecossistemas e a a va liação de alterações decorrentes do estabelecimento de planta ções. Em relação à deposição de material orgānico e de nutrien tes, consideramos de caráter prioritārio a obtenção de dados sobre:

a. ciclo biológico de nutrientes em plantações flores tais e em formações vegetais, especialmente no cer rado, abrangendo:

a.1. deposição anual de material orgānico (com amos tragem adequada para as diversas frações envol vidas) e de nutrientes, incluindo lavagem fol $\underline{i}$ ar;

a.2. retenção anual de nutrientes na biomassa (di s criminando madeira comercial, casca e copa, no caso de plantações);

a.3. quantificação de nutrientes do piso florestal e do solo; e

a.4. velocidade de decomposição do material orgāni co caído;

b. produtividade primāria līquida em plantações flo restais e em cerrados e outras formações vegetais;

c. sistemas radiculares de espécies de Pinus e Eucalyp tus; $\mathrm{e}$

d. fenologia de crescimento de espécies de Pinus e Eu calyptus. 


\section{CONCLUSÕES}

Com base nos resultados e em sua discussão, pọ de-se concluir que:

a) em ambos os ecossistemas investigados, a amos tragem por bandejas de $1 \mathrm{~m}^{2}$ mostrou-se adequada apenas para a fração foliar;

b) a mensuração da deposição de ramos, caules, cascas e miscelānea requer a adoção de parcelas de amostragem adequadas para cada uma destas frações;

c) a variação estacional da deposição foliar foi diferente nos 2 ecossistemas: o perīodo de māxima deposição ocorreu, aproximadamente, de agosto a novembro na mata, e de dezembro a fevereiro no eucaliptal;

d) considerando a sobreposição dos valores de média t desvio padrão da média, a deposição total anual de ma terial orgānico e a deposição foliar foram maiores na mata;

e) em comparação com dados obtidos por amostra gem com bandejas, a deposição anual de material orgānico do eu caliptal é considerada normal para sua latitude, enquanto a da mata é elevada, equiparando-se aos maiores valores de flores tas tropicais ümi da;

f) no eucaliptal o valor da relação entre depọ 
sição foliar anual e ārea basal foi de $231 \mathrm{~kg} / \mathrm{m}^{2}$, prōximo a va lores encontrados em plantações de Eucalyptus saligna em Pira cicaba, SP;

g) as concentrações de nutrientes nas frações do material orgânico depositado säo consideravelmente maiores na mata que no eucaliptal;

h) as quantidades de nutrientes depositadas na mata são bastante superiores às depositadas no eucaliptal, e podem ser consideradas elevadas em termos mundiais; e

i) as concentrações de nutrientes do material deciduo e as quantidades de nutrientes depositadas no eucalip tal de Lençóis Paulista podem ser consideradas normais, quando comparadas com resultados determinados em outros ecossistemas de Eucalyptus. 


\section{SUMMARY}

Brazil has an area of approximately 2.5-3 million hectares planted with fast-growing Eucalyptus and Pinus species and their annual expansion area is about 200-250 thousand hec tares. Present knowledge on the ecological aspects of man-made and natural forests is insufficient to allow a precise evalua tion of the dynamics of the ecossystems, or the risks and the benefits of man-made forests. A comprehension of the biological nutrient cycle is considered as being an importantinicial step towards understanting the ecossystems.

This paper deals with the litter fall and $i$ ts nutrient content in two contiguous forest ecossystems at Len çóis Paulista in the State of São Paulo. The first is a natu ral mature riparian subtropical semideciduous forest, and the second is a 4 to 5 years old eucalypt plantation $160 \%$ Eucalyptus saligna Smith and $40 \% E$. grandis Hill ex Maiden). The eucalypt plantation replaced the local natural vegetation, a cerrado (a like-savanna vegetation). The soil under the eucalypt plantation is sandy and not as rich as that under the natural forest wich has a higher clay percentage. Litter was collected in $1 m^{2}$ traps for 15-16 months, divided into leaf, twigs and miscellaneous fractions and analyzed for $\mathrm{N}, \mathrm{P}, \mathrm{K}, \mathrm{Ca}$ and $\mathrm{Mg}$. Sampling for litter collection showed to be ade 
quate only when measuring leaf fall. Traps can be used to meas ure the miscellaneous fraction in similar natural forests, since modifications in the sampling technique are made. For mensuration of the bark and wood (including large branches and stems) frac tions, sampling plots other than the traditional traps are sug gested.

The annual means of litter fall and its nutrient content we re:

\begin{tabular}{|c|c|c|c|c|c|c|}
\hline \multirow{2}{*}{ Vegetation } & \multirow{2}{*}{$\begin{array}{l}\text { Litter fall } \\
\ldots(\mathrm{Kg} / \mathrm{ha})\end{array}$} & \multicolumn{5}{|c|}{ Nutrients $(\mathrm{Kg} / \mathrm{ha})$} \\
\hline & & $\mathrm{N}$ & $P$ & K & $\mathrm{Ca}$ & $\mathrm{Mg}$ \\
\hline \multicolumn{7}{|l|}{ Natural forest } \\
\hline Total & 10503 & 202,5 & 11,25 & 71,9 & 239,6 & 31,2 \\
\hline Leaf & 6740 & 138,7 & 7,20 & 54,1 & 155,9 & 22,4 \\
\hline \multicolumn{7}{|c|}{ Euca lypt plantation } \\
\hline Total & 7568 & 39,7 & 2,89 & 11,1 & 34,8 & 15,5 \\
\hline Leaf & 4687 & 32,5 & 2,29 & 9,5 & 24,5 & 11,7 \\
\hline
\end{tabular}

Leaf fraction was the main fraction collected in the traps and it corresponded to about two thirds of the to tal litter fall in both ecossystems. The natural forest leaf fall increased in the normally dry season and the eucalypt plan tation leaf fall increased in the wet and hot season.

Mean annual leaf fall and mean annual total lit ter fall were higher in the natural forest than in the eucalypt plantation. When compared to other data obtained by the litter trap method the values found for the local natural forest are considered high for the latitude and are closer to those values normally obtained for rainy tropical forests. If included in the same comparison the values found for the eucalyptplantation can be considered normal for the latitude. For the fast growing 
eucalypt plantations in the State of São Paulö there seems to be a mean annual leaf fall and basal:area ratio wich value is about $230-260 \mathrm{~kg} / \mathrm{m}^{2}$.

The values for nutrient concentration and nutri ent content of the natural forest litter fall are similar to the highest values found for other world ecossystems. The corre spondent values for the eucalypt plantation are similar to those of other Eucalyptus ecossystems, and sharply lower than those values of the natural forest.

The litter fall and its nutrient deposition are only parts of the ecossystem dynamics. Without information on other related aspects, the litter fall and its nutrient content can not be correctelly understood neither be used for practical purposes. A set of requested and related subjects is given as a guide to establish further investigations. 


\section{LITERATURA CITADA}

AKAI, T. e T. FURON0, 1971. Amounts of 1 itter fall and grazing (i.e. insect feeding) in young Loblolly Pine forest. Buzletin of the kyoto University Forests. Kyoto, (42): 83-95. Apud: Forestry Abstracts, 0xford, 33 (2): 226, 1972.

ANDRADE, E. N. de, 1940. The eucalyptus in Brazil. Journal of Heredity. Baltimore, 12:215-220 e 240 .

ANDRADE, E. N. de, 1961. O eucalipto. 2a. ed. Jundiaŕ. Compa nhia Paulista de Estradas de Ferro. 679 p.

ARAujo, V. C. de, 1970. Fenologia de essencias florestais Ama zônicas I. Boletim do INPA. Manaus, (4): 1-25. (Série Pes quis as Florestais).

ASHTON, D. H., 1975. Studies of 1 itter in Eucalyptus regnans for ests. Australian Journal of Botany. Melbourne, 23:413-433.

ATTIWILL, P. M., 1966. The chemical composition of rainwater in relation to cycling of nutrients im mature Eucalyptus for ests. Plant and Soiz. Wageningen, 24 (3): 390-406.

ATTIWILL, P. M., 1968. The loss of elements from decomposing litter. Ecology. Durham, 49 (1): 142-145. 
AUSSENAC, G., M. BONNEAU e F. Le TACON, 1972. Restitution of min eral elements to the soil, trough the litter and trough pre cipitation, in three forest stands of eastern France. Oeco Zogia PZantarum. (Paris), ? (1): 1-21. Apud: Forestry A $\underline{b}$ stracts, 0xford, 34 (2): 65, 1973.

AUSTRALIA, 1967. Rates of 1itter fall in Pinus and Eucalyptus forests. In: Report of the Forest and Timber Bureau, 1966. (s.1.), (s.ed.), p. 29-30. Apud: Forestry Abstracts, 0xford, $29(4): 582,1968$.

BAKER, F. S., 1950. Principles of sizviculture. Nova Iorque, Mc Graw-Hi11 Book Company, Inc: 414 p.

BARROS, N. F. e R. M. BRANDI, 1975. Influēncia de trēs espécies florestais sobre a fertilidade de solo de pastagem em Viço sa, MG. Brasil Florestal. Rio de Janeiro, 6 (21): 24-29.

BERNHARD-REVERSAT, F., 1967. Essai de comparaison des cicles d'étèments minéraux dans les plantations de Framiré (Termí nalia ivorensis) et en forêt naturelle de Cote DiIvoire. Bois et Forêts des Tropiques. Nogent Sur-Marne, (167): 2538 .

BERUTTI, P., 1977. Importāncia do incentivo fiscal à política brasileira de reflorestamento. Brasil Florestal. Brasilia, $8(31): 30-34$.

BORMANN, H.. F. e G. E. LIKENS, 1970. The nutrient cycles of an ecossystem. Scientific American. Nova Iorque, (233): 93-101.

BRAY, J. R. e E. GHORAM, 1964. Litter production in forests of the world. Advances in Ecological Research. Londres, 2:101157 .

CARLISLE, A., A. H. F. BROWN e E. J. WHITE, 1966. The organic matter and nutrient elements in the precipitation beneath a 
sessile oak (Quercus petraea) canopy. Journal of Ecology. 0xford, 54 (1): 87-98.

CARPANEZZI, A. A., 1975. Relatório de bolsista à Duraflora Sị vicultura e Comércio Ltda. 127 p. (datilografado)

CARVALHO, J. 0. P. de, 1978. Inventário diagnóstico da regene rąão natural de uma área na Floresta Nacional do Tapajós. Trabalho apresentado ao 39 Congresso Florestal Brasileiro, em Manaus. $27 \mathrm{p}$.

CHRISTENSEN, 0., 1975. Woody 1 itter fall in relation to abcission, environmental factors, and the decomposition cycle in a Danish oak forest. Oikos (Copenhague), 26 (2): 187-195. Apud: Forestry Abstracts, 0xford, 36 (6): 303, 1975.

CLEMENTE, A. M. 1976. Potēncia Florestal. Sizvicuztura, São Pau 10, $1(3): 10.13$.

COILE, T. S. 1937. Composition of the leaf litter of forest trees. Soiz science. Baltimore, 43 (5): 349-355.

CORNFORTH, I. S., 1970. Leaf-fall in a tropical rain forest. Journal of Applied Ecology. 0xford, ? (3): 603-608.

Cozzo. D., 1971. La deposición de material orgānico durante 2 anos en el suelo de un bosquete de Eucalyptus camaldulensis de 8-9 años. Revista Forestal Argentina. Buenos Aires, 15 (1): $5-7$.

Cozzo, D., 1972. Registro de la hojarasca caída en el suelo de una plantaciōn.joven de Pinus canariensis. Revista Forestal Argentina. Buenos Aires, 16 (3-4): 102-104.

Cozzo, D., 1974. La cantidad de materia orgánica depositada en el suelo por una plantación de Robinia pseudoocacia. Revista Forestal Argentina. Buenos Aires, 18 (3): 67-69. 
CURLIN, J.W., 1970. Nutrient cycling as a factor in site pro ductivity and forest utilization. In: YOUNGBERG, C.T. e C.B. DAVEY, Ed. Tree Growth and Forest Soils. Corvallis, Oregon State University Press, p. 313-325.

DENAEYER-DE SMET, S., 1969. Studies on the forest ecossystem. Series $B$ : The mixed calciphille oak forest of VirellesBlaimont. Contribution No. 29. Contribution of mineral ele ments from precipitation, drip, and stem-flow (1965, 1966, 1967). Buzletin. Societé Royale de Botanique de Belgique. (Bruxelas), 102 (2): 355-372. Apud: Forestry Abstracts, 0xford, $31(3): 500,1970$.

DENEY, D., 1975. The return of nutrient elements to the soil by leaf-fall in young Poplar plantations. Gorsko Stopanstvo. (S. T), 31 (10): 13-17. Apud: Forestry Abstracts, 0xford, 37 (8): 448,1976 .

DOMMERGUES, Y., 1963. Les cycles biogēochimiques des ēlements minēraux dans les formations tropicales. Bois et Forêts des Tropiques. Nogent Sur-Marne, (87): 9-25.

DUVIGNEAUD, P., 1977. A Sintere Ecológica: popuzações, comuni dades, ecossistemas. Lisboa, Socicultur. 10 vol. 168 p.

DUVIGNEAUD, P. e S. DENAEYER-DE SMET. Biologicàl cycling of minerals in temperate deciduous forests. In: REICHELE, D. E., Ed. Analysis of Temperate Forest Ecossystems. Nova Ior que, Springer-Verlag, p. 199-225.

EATON, J. S., G. E. LIKENS e F. H. BORMANN, 1973. Troughfall and stemflow chemistry in a northern hardwood forest. Journal of Ecology. 0xford, 61 (2): 495-508.

EDWARDS, P. J., 1977. Studies of mineral cycling in a montane rain forest in New Guinea. Journal of Ecology. 0xford, 65 (3): $971-992$. 
EGUNJOBI, J. K., 1974. Litter fall and mineralization in a Teak (Tectona grandis) stand. Oikos. Copenhague, 25 (2): 222-226.

EPSTEIN, E., 1975. Nutricão Mineral das PZantas: principios e perspectivas. Rio de Janeiro, Livros Técnicos e Científicos Editora S.A. e Editora da Universidade de São Paulo. 341 p.

EWEL, J. J., 1976. Litter fall and leaf decomposition in a trop ical forest succession in eastern Guatemala. Journal of Eco Zogy. 0xford, 64 (1): 293-308.

FACCHINI, J. A., 1970. Situação presente do abastecimento e con sumo de madeira duras. Silvicuitura em São Paulo. São Paulo, $7: 7-18$.

FERRI, M. G., 1964. Informaçōes sobre a ecologia dos cerrados e sobre a possibilidade de seu aproveitamento. Silvicultura em Säo Pauzo. São Paulo, 3: 43-60.

FLORENCE, R. G. e D. LAMB, 1974. Influence of stand and site on radiata pine litter in South Australia. New Zealand Jour nal of Forestry Science. Rotorua, 4 (3): 502-510.

FOSTER, N. W. 1974. Annual macroelement transfer from Pinus banksiana Lamb. to soi1. Canadian Journal of Forest Research. Ot tawa, 4 (4): 470-476.

FOURNIER, L. A. e L. CAMACHO DE CASTRO, 1973. Producción y de composición del mantillo en un bosque secundario hümedo de premontano. Revista de Biologia Tropical. San José, 21 (1): 59-67.

FURONO, T. e K. YAMADA, 1975. Investigations on the producti $\underline{v}$ ity of japanese Fir (Abies firma Sib. et Zucc) and Hemlock (Tsuga sieboldii) stands in Kyoto University Forest in Wakayama. (III) Seasonal variation of 7 itter fall and primary consump tion by herbivorous insects in the mixed fir and hemlock 
stand. Bulzetin of the Kyoto University Forests. Kyoto, (46): 7-22. Apud: Forestry Abstracts, 0xford, 36 (10): 534, 1975 .

GESSEL, S. P. e J. TURNER, 1974. LItter production by red alder (Alnus rubra) in Western Washington. Forest Science, 20 (4): 325-330.

GOLFARI, L., 1967. Conîferas aptas para repoblaciones foresta les em el Estado de São Paulo. Silvicultura em São Pauzo. São Paulo, 6: 7-62.

GOLLEY, F. B., J. I. MC GINNIS, R. G. CLEMENTS, G. I. CHILD e M. J. DUEVER, 1975. Mineral Cycling in a Tropical Moist Forest Ecossystem. Athens, University of Georgia Press. 248 p.

GOLFARI, L., R. L. CASER e V. P. G. MOURA, 1978. Zoneamento eco lógico esquemätico para reflorestamento no Brasil (2a. Apro ximą̧ão). Brasīila, PRODEPEF. 66 p. (Série Técnica, 11).

GOODLAND, R., 1979a. História dos trabalhos do cerrado até 1968. In: GOODLAND, R. e M. G. FERRI. Ecologia do cerrado. Belo Ho rizonte, Livraria Itatiaia Editora Ltda. e Editora da Uni versidade de São Paulo, p. 13-20.

GOODLAND, R., 1979b. Anālise ecológica da vegetação do cerrado. In: GOODLAND, R. e M. FERRI. Ecologia do Cerrado. Belo Ho rizonte, Livraria Itatiaia Editora Ltda e Editora da Univer sidade de São Paulo, p. 61-161.

GOSZ, J., G. E. LIKENS e F. H. BORMANN, 1972. Nutrient content of 1 itter fall on the Hubbard Brook Experimental Forest, New Hampshire. Ecology. Durham, 53 (5): 769-784.

GRUBB, P. J., 1977. Control of forest growth and distribution on wet tropical mountains: With special reference to mineral nutrition. Annual Review of Ecology and Systematics. Palo 
A1 to, 8: 83-108.

GRUNERT, F., 1964. The biological nutrient cycle in mixed Scots Pine/Beech, and in Scots Pine stands. Albrecth-Thaer Archiv. Berlim, $8(6-7):$ 435-452. Apud: Forestry Abstracts, 0xford, 27 (1): 36,1966 .

HAAG, H. P., J.R. SARRUEE, G. D. de OLIVEIRA, F. POGGIANI e C. A. FERREIRA, 1976. Anālise foliar em cinco espécies de eu caliptos. IPEF. Piracicaba, (13): 99-115.

HEILMAN, P. E., 1961. Effect of nitrogen fertilization on the growth and nitrogen nutrition of low-site Douglas-fir stands. Dissertation Abstracts. (S.1\%), 22 (5): 1336. Apud: Forestry Abstracts, 0xford, 23 (3): 421, 1962.

HENDERSON, G. S., W. F. HARRIS, D. E. TODD, JR e T. GRIZZARD, 1977. Quantity and chemistry of troughfall as influenced by forest-type and season. Joumaz of Ecology. 0xford, 65 (2): $365-374$.

HOMEM, V. P., 1959. A cultura do eucalipto. Sua importāncia no melhoramento dos solos. Anuärio Brasileiro de Economia Flo restal. Rio de Janeiro, 11: 146-154.

HOPKINS, B., 1966. Vegetation of the 010 kemeji Forest Reserve, Nigeria. IV. The litter and soil with special reference to their seasonal changes. Journal of Ecology. 0xford, 54:687704 .

HUECK, K., 1972. As florestas da Amërica do SuZ. São Paulo, Edi tora Polígono e Editora da Universidade de Brasilia. $466 \mathrm{p}$.

HURD, R. M., 1971. Annual tree-1itter production by succession al forest stands, Juneau, Alasca. Ecology. Durham, 52 (5): $881-884$.

JOHNSON, F. L. e P. G. RISSER, 1974. Biomass, annual net prima 
ry production, and dynamics of six mineral elements in a post oak-blackjack oak forest. Ecology. Durham, 55 (6): $1246-1258$.

JOHNSTON, R. S. E D. L. BARTOS, 1977. Summary of nutrient and biomass data from two aspen sites in Western United States. Ogden, USDA Forest Service. 15p. (Research Note INT-227).

JORGENSEN, J. R., C. J. WELLS e L.J. METZ, 1975. The nutrient cycle: key to continous forest production. Journal of Fores try. Washington, D. C., 73 (7): 400-403.

KAWAHARA, T. e T. TSUTSUMI, 1971. The return of nutrients with litter-fall in the forest ecossystem (I). Seasonal variation of nutrient concentration. Bulletin of the Kyoto University Forests. Kyoto, (42): 96-102. Apud: Forestry Abstracts, 0x ford, 33 (a): 226, 1972 .

KLINGE, H. e W. A. RODRIGUES, 1968a. Litter production in an area of amazonian terra firme forest. Part I. Litter-fall, organic carbon and total nitrogen contents of litter. Ama zoniana. Kiel, 1 (4): 278-302-

KLINGE, H. e W. A. RODRIGUES, 1968b. Litter production in an area of amazonian terra firme forest. Part II. Mineral nutri ent content of the litter. Amazoniana. Kiel. 1 (4): 303-310.

KRAMER, P. J. e T. KOSLOWSKI, 1972. Fisiologia das Ärvores. Lí boa, Fundação Calouste Gulbenkian. 745p.

LAMB, D. e R. G. FLORENCE, 1975. Influence of soil type on the nitrogen and phosphorus content of radiata pine litter. New Zealand Journal of Forestry Science. Rotorua, 5 (2):143-151.

LANG, G. E., 1974. Litter dinamics in a mixed oak forest on the New Jersey Piedmont. Bulletin of the Torrey Botanical Club. Nova Iorque, 101 (5): 277-286. 
LESLIE, A., 1977. Where contradictory theory and practice coexist. Unasyzva. Roma, 29 (115): 2-17.

LIMA, W.P., 1975. Efeito de plantações de Eucalyptus e Pinus sobre a qualidade da água da chuva. IPEF. Piracicaba, (11): 23-35.

LUBRANO, L., 1967. Research on the nutrient-demand of some spe cies of Eucalyptus. In: FAO. World Symposium on Man-made For ests and their Industrial Importance at Camberra. Section II. Sizviculture. Roma, p. 1801-1826.

MADGE, D.S., 1965. Leaf fall and litter disappearance in a trop ical forest. Pedobiologia. Jena, $5(4): 273-288$. Apud: For estry Abstracts, 0xford, 28 (1): 26, 1967.

MAHEUT, J. e Y. DOMMERGUES, 1960. Les Teckeraies de Casamance. Capacité de production des peuplements, caractéristiques biologiques et maintien du potentiel producif des sols.Bois et Forêts del Tropiques. Nogent Sur-Marne, (70): 25-42.

MAKI, T.E., 1961. Some effects of fertilizers on Loblolly Pine. In: Transactions of the 7 th Internacional Congress on Soil Science at Madison. (S. 1.), (S.ed.).3: 363-376. Apud: For estry Abstracts, 0xford, 23 (4): 609, 1962.

MALAISSE, F., R. FRESON, G. GOFFINET e M. MALAISSE-MOUSSET, 1975. Litter fall and litter breakdown in miombo. In: GOLLEY, F. B. e E. MEDINA. Ed. Tropical Ecologycal Systems: Trends in Terrestrial and Aquatic Research. Nova Iorque, SpringerVerlag, p. 137.152 .

Mc COLL, J.G., 1966. Acession and decomposition of litter in spotted gum forests. Australian Forestry. Melbourne, 30(3): 191-198.

Mc COLL, J. G., 1969. Soil-plant relationships in a Eucalyptus 
forest the south coast of New South Wales. Ecology, Durham, $50(3): 354-362$.

MEDWECKA-KORNAS, A., 1971. Plant litter. In: PHILLIPSON, J., Ed. Methods of Study in Quantitative Soir Ecology: popula tion, production and energy flow. 0xford, Blackwell Scien tific Publications, p. 24-33 (IBP Handbook No. 18).

MEGURo, M., 1973. Ecologia Vegetal. São Paulo, Instituto de Biociēncias da Universidade de São Paúlo. 95 p. (mimeografa do).

METRO, A. E e A. G. de BEUACORPS, 1958. Influência dos povoa mentos de eucaliptos sobre a evolução dos solos arenosos do Rharb. Fertizité. Paris, (4): 3-13.

MILLER, H. G., J. M. COOPER e J. D. MILLER, 1976a. Effect of nitrogen supply on nutrients in litter fall and crown lea ching in a stand of Corsicam Pine. Journal of Appiied Eco Zogy. 0xford, $13(1): 233-248$.

MILLER, R. E., D. P. LAVENDER e C. C. GRIER, 1976b. Nutrient Cycling in the Douglas-fir type - Silvicultural implications. In: SOCIETY OF AMERICAN FORESTERS. Proceedings, 1975 Annual Convention. (S. 1.), p. 359-390.

MORRISON, J. K., 1973. Distribution of elements in aereal com ponents of several natural Jack pine stands in northern 0n tario. Canadian Journal of Forest Research. 0ttawa, 3 (2): $170-179$.

NYE, P. H., 1961. Organic matter and nutrient cycles under moist tropical forest. Pzant and Soiz. Wageningen, 13 (4):333-346.

NYKVIST, N., 1969. Is forest soil being impoverished (by va rious logging methods)? Skogsagarem. (S. 1.), 44 (8): 14-15. Apud: Forestry Abstracts, 0xford, 30 (1): 80, 1969. 
ODUM, E.P., 1975. Ecologia. 2a. ed. São Paulo, Livraria Pionei ra Editora e Instituto Nacional do Livro. $201 \mathrm{p}$.

OVINGTON, J.D., 1962. Quantitative ecology and the woodland ecossystem concept. Advances in Ecological Research. Londres, 1: $103-192$.

OVINGTON, J.D., 1968. Some factors affecting nutrient distri bution. In: ECKARDT, F. E., Ed. Functioning of terrestrial ecosystems at the primary production level. Proceedings of the Copenhagen Symposium. (S. 1), UNESCO, 95-105.

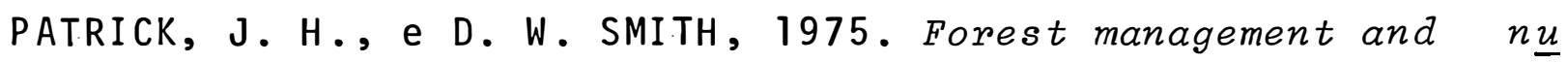
trient cycling in eastern hardwoods. (S. 1.), USDA Forest Service. 12 p. (Research Paper NE - 324).

PHILLIPSON, J., R. J. PUTMAN, J. STEEL e S. R. J. WOODEL, 1975. Litter imput, litter decomposition and the evolution of car bon dioxide in a beech woodland-Wytham Woods, 0xford. Oeco Zogia. Berlim, 20: 203-217.

POGGIANI, F., 1976. Ciclo de nutrientes e produtividade da flo resta implantada. Silvicultura. São Paulo, 1 (3): 45-48.

POGGIANI, F., 1978. Adaptação ecológica, crescimento e desen volvimento dos pinheiros tropicais. Piracicaba, Escola Supe rior de Agricultura Luiz de Queiroz. Departamento de Recur sos Naturais Renováveis. $10 \mathrm{p}$.

POLI, E., S. LEONARDI e S. BELA, 1974. Litter production in the Quercus ilex forest on Mount Minardo (Etna) from Sept. 1970 to June 1974. Archivio Botanico. (S. 1.), 50: 87-107.' Apud: Forestry Abstracts, 0xford, 37 (9): 504, 1976.

PRITCHETT, W. L., 1979. Properties and management of forest soils. Nova Iorque, John Wiley and Sons. $500 \mathrm{p}$.

REINERS, W. A., 1972. Nutrient contents of canopy troughfall 
in three Minnesota forests. Oikos. (Copenhague), 23 (1): 14-22. Apud: Forestry Abstracts, 0xford, 35 (5): $210,1974$.

REUKEMA, D. L., 1964. Litter fall in a young Douglas-fir stand. (S. 1.), USDA Forest Service. $8 \mathrm{p}$. (Research Note PNW-14). Apud: Forestry Abstracts, 0xford, 26 (2): 191, 1965.

RIZZINI, C. T., 1979. Tratado de Fitogeografia do Brasil. São Paulo, Editora de Humanismo, Ciência e Tecnologia HUCITEC Ltda e Editora da Universidade de São Paulo. 20 vol. 374 p.

RIZZO, J. A., A. J. CENTENO, J. S. LOUSA E T. S. FIlgUEIRAS, 19.71. Levantamento de dados em āreas de cerrado e da flores ta caducífólia tropical do planalto centro-oeste. In: FERRI, M. G., Coord. III Simpósio sobre o Cerrado. São Paulo, Edi tora Edgard B.lucher Ltda e Editora da Universidade de Brasi lia. p. 103-109.

ROMARIZ, D. de A., 1974. Aspectos da Vegetą̧o do Brasiz. Rio de Janeiro, IBGE. $60 \mathrm{p}$.

SAIDO, H. e T. SHIDEI, 1972. Studies on estimation of leaf fall under model canopy. BuZZetin of the Kyoto University For ests. (Kyoto), (43): 162-185. Apud: Forestry Abstracts, 0므 ford, $34(10): 509,1973$.

SAMRAJ, P., S. CHINNAMANI e B. HALDORAI, 1977. Natural versus man-made forest in Nilgiris with special reference to runoff, soil loss and productivity. Indian Forester. Calcutá. $103(7): 460-5$.

SARRUGE. J. R. e H. P. HAAG. 1974. Anālises quỉmicas em plan tas. Piracicaba, Departamento de Quîmica da Escola Superior de Agricultura Luiz de Queiroz, $56 \mathrm{p}$.

SAUVAGEOT, A.; 1973. Research on the mineral nutrition of $P \underline{i}$ nus pinaster in the forest of Mamora. Annazes de la Recherche 
Forestiène au Maroc. (Rabat), 13: 3-62. Apud: Forestry A $\underline{b}$ stracts, 0xford, 35 (12): 733, 1974.

SETH, S. K., 0. N. KAUL e A. C. GUPTA, 1963. Some observations on nutrition cycle and return of nutrients in plantations at New Forest. Indian Forester. Calcutā, 89: 90-98.

SETZER, J., 1966. Atlas Climätico e Ecológico do Estado de são Pauzo. São Paulo, Comissão Interestadual da Bacia Paranā Uruguai e Centrais Elêtricas do Estado de São Paulo. 61 p.

SMITH, W. H., 1976. Character and significance of tree root exsudates. Ecology. Durham, 57 (2): 324-331.

SPECHT, R. L. e Y. M. BROUWER, 1975. Seasonal shoot growth of Eucalyptus spp in the Brisbane area of Queensland (with no tes on shoot growth and litter fall in other areas of Aus tralial. Australian Journal of Botany. Melbourne, 23: 459474.

SPURR, S. H. e V. B. BURTON, 1973. Forest Ecology. 2a. ed. Nova Iorque, The Ronald Press Company $571 \mathrm{p}$.

STARK, N., 1971. Nutrient cycling II: Nutrient distribution in Amazonian vegetation. Tropical Ecology. Varanasi, 12 (2): 177-201.

STREET, H. E e H. ÖPIK, 1974. Fisiologia das angiospermas: cres cimento e desenvolvimento. São Paulo, Editora Polígno e Edi tora da Universidade de São Paulo. $315 \mathrm{p}$.

SVIRIDOVA, I. K., 1960. Role of tending operations (thinnings) in increasing the fertility of forest soils.. Pocvoved (S. 1.), (4): 68-73. Apud: Forestry Abstracts, 0xford, 21 (4): 586, 1960 .

SYKES, J. M. e R. G. H. BUNCE, 1970. Fluctuations in litter 
fall in a mixed deciduous wooldland over a three-year peri od in 1966-68. Oikos. (Copenhague), 21 (2): 326-329. Apud: Forestry Abstracts, 32 (4): 642. 1971.

TADAKI, Y. e T. KAGAMA, 1968. Studies on the production struc ture of forest. XIII. Seasonal changes of litter-fall in some evergreen stands. Journal of the Japaneses Forestry So ciety. (S. 1.), 50 (1): 7-13. Apud: Forestry Abstracts, 0므 ford, 29 (4): $582,1968$.

TAPPEINER, J. C. A A. A. ALM, 1972. Effect of Haze 1 on the nu trient composition of annual 1 itter and forest floor in Jack and Red Pine Stands. Minnesota Forestry Research Notes.(S.1), (235): 1-4. Apud: Forestry Abstracts, 0xford, 35 (4): 139 , 1972.

TARRANT, R. F. et alii, 1968. Nutrient cycling by trough fall and stemflow precipitation in three coastal oregon forest types. (S.1.), USDA Forest Service. 7 p. (Research Note PNW-54). Apud: Forestry Abstracts, 0xford, 30 (3): 436, 1969.

TURNER, J., D. W. COLE e S. P. GESSEL, 1976. Mineral nutrient accumulation and cycling in a stand of red alder (Alnus rubral. Journal of Ecology. Oxford, 64 (3): 965-974.

WARMING, E., 1973. Lagoa Santa. In: WARMING, E. Lagoa Santa e FERRI, M. G. A Vegetação de Cerrados Brasizeiros. Belo Hori zonte, Livraria Itatiaia Editora Limitada e Editora da Uni versìdade de Säo Pauto, p. 1-284.

WEBB, I. J., J. G. TRACEY, W. T. Williams e G. N. LANCE, 1969. The pattern of mineral return in leaf litter of there sub tropical Australian forests. Australian Forestry. Melbourne, 33: $99-110$.

WELLS, C., D. WIGHAM e H. LIETH, 1972. Investigations of min eral nutrient cycling in upland Piedmont forest. Journal of 
the EIisha MitcheII Scientific Society. (Chapel Hill), 88 (2): 66-78. Apud: Forestry Abstracts, 0xford, 35 (4): 139, 1974 .

WILL, G. M., 1959. Nutrient return in 1 itter and rainfall un der some exotic conifer stands in New Zealand. New Zealand Journal of Agricultural Research. (S. 1.), 2 (4): 719-734.

YOUNG, H. E., 1971. Preliminar estimates of bark percentages and chemical elements of complete trees of eight species in Maine. Forest Products Journal. Madison, 21 (5): 56-59-

ZAVITKOVSKI, J. e M. NEWTON, 1971. Litter fall and 1itter accu mulation in red alder stands in western Oregon. Plant and Soiz. Wageningen, 35:257-268. 